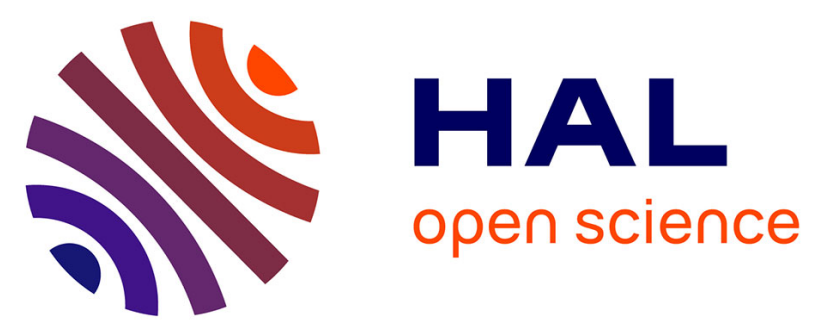

\title{
Reconstructing fluid-flow events in Lower-Triassic sandstones of the eastern Paris Basin by elemental tracing and isotopic dating of nanometric illite crystals
}

Thomas Blaise, Norbert Clauer, Michel Cathelineau, Marie-Christine Boiron, Isabelle Techer, Philippe Boulvais

\section{To cite this version:}

Thomas Blaise, Norbert Clauer, Michel Cathelineau, Marie-Christine Boiron, Isabelle Techer, et al.. Reconstructing fluid-flow events in Lower-Triassic sandstones of the eastern Paris Basin by elemental tracing and isotopic dating of nanometric illite crystals. Geochimica et Cosmochimica Acta, 2016, 176, pp.157-184. 10.1016/j.gca.2015.12.018 . insu-01250051

\section{HAL Id: insu-01250051 https://hal-insu.archives-ouvertes.fr/insu-01250051}

Submitted on 4 Jan 2016

HAL is a multi-disciplinary open access archive for the deposit and dissemination of scientific research documents, whether they are published or not. The documents may come from teaching and research institutions in France or abroad, or from public or private research centers.
L'archive ouverte pluridisciplinaire HAL, est destinée au dépôt et à la diffusion de documents scientifiques de niveau recherche, publiés ou non, émanant des établissements d'enseignement et de recherche français ou étrangers, des laboratoires publics ou privés. 


\section{Accepted Manuscript}

Reconstructing fluid-flow events in Lower-Triassic sandstones of the eastern Paris Basin by elemental tracing and isotopic dating of nanometric illite crystals

Thomas Blaise, Norbert Clauer, Michel Cathelineau, Marie-Christine Boiron, Isabelle Techer, Philippe Boulvais

PII: S0016-7037(15)00712-7

DOI: http://dx.doi.org/10.1016/j.gca.2015.12.018

Reference: GCA 9550

To appear in:

Geochimica et Cosmochimica Acta

Received Date: $\quad 23$ November 2014

Accepted Date: $\quad 17$ December 2015

Please cite this article as: Blaise, T., Clauer, N., Cathelineau, M., Boiron, M-C., Techer, I., Boulvais, P., Reconstructing fluid-flow events in Lower-Triassic sandstones of the eastern Paris Basin by elemental tracing and isotopic dating of nanometric illite crystals, Geochimica et Cosmochimica Acta (2015), doi: http://dx.doi.org/ 10.1016/j.gca.2015.12.018

This is a PDF file of an unedited manuscript that has been accepted for publication. As a service to our customers we are providing this early version of the manuscript. The manuscript will undergo copyediting, typesetting, and review of the resulting proof before it is published in its final form. Please note that during the production process errors may be discovered which could affect the content, and all legal disclaimers that apply to the journal pertain. 


\section{Reconstructing fluid-flow events in Lower-Triassic sandstones \\ of the eastern Paris Basin by elemental tracing and \\ isotopic dating of nanometric illite crystals}

Thomas Blaise $^{(1)}$, Norbert Clauer ${ }^{(2)}$, Michel Cathelineau ${ }^{(1)}$, Marie-Christine Boiron $^{(1)}$, Isabelle Techer ${ }^{(3)}$ and Philippe Boulvais ${ }^{(4)}$

(1) UMR 7359 CNRS, Géoressources, Université de Lorraine, Boulevard des Aiguillettes, BP 70239, 54506 Vandœuvre-lès-Nancy, France

(2) Laboratoire d'Hydrologie et de Géochimie de Strasbourg (CNRS-UdS), Université de Strasbourg, 1 rue Blessig, 67084 Strasbourg, France

(3) Equipe d'Accueil EA 7352 CHROME, Université de Nimes, rue du Dr. Georges Salan, 30021 Nimes, France

(4) Géosciences, UMR 6118 CNRS - OSUR, Université de Rennes 1, 35042 Rennes, France

corresponding author: Dr. Norbert Clauer, Laboratoire d'Hydrologie et de Géochimie de Strasbourg (CNRS/UdS), 1 Rue Blessig, 67084 Strasbourg, France; office phone: (33) 36885 04 33; cell phone: (33) 6800180 49; fax: (33) 3688504 02; e-mail: $\underline{\text { nclauer@unistra.fr }}$

\section{Abstract}


Lower- to Middle-Triassic sandstones from eastern Paris Basin were buried to a maximum depth of $2500 \mathrm{~m}$ at a paleo-temperature of about $100{ }^{\circ} \mathrm{C}$. They contain extensive amounts of authigenic platy and filamentous illite particles similar to those reported in reservoirs generally buried at 3000 to $5000 \mathrm{~m}$ and subjected to temperatures of 120 to $150{ }^{\circ} \mathrm{C}$. To evaluate this unexpected occurrence, such sandstones were collected from drill cores between 1825 and $2000 \mathrm{~m}$ depth, and nanometric-sized sub-fractions were separated. The illite crystals were identified by XRD, observed by SEM and TEM, analyzed for their major, trace, rare-earth elements and oxygen isotope compositions, and dated by $\mathrm{K}-\mathrm{Ar}$ and $\mathrm{Rb}-\mathrm{Sr}$.

Illite particles display varied growth features in the rock pore space and on authigenic quartz and adularia that they postdate. TEM-EDS crystal-chemical in situ data show that the illite lath/fiber and platelet morphologies correspond at least to two populations with varied interlayer charges: between 0.7 and 0.9 in the former and between 0.8 and 1.0 in the latter, the $\mathrm{Fe} / \mathrm{Fe}+\mathrm{Mg}$ ratio being higher in the platelets. Except for the deeper conglomerate, the PAASnormalized REE patterns of the illite crystals are bell-shaped, enriched in middle REEs. Cacarbonates and Ca-phosphates were detected together with illite in the separates. These soluble components yield ${ }^{87} \mathrm{Sr} /{ }^{86} \mathrm{Sr}$ ratios that are not strictly in chemical equilibrium with the illite crystals, suggesting successive fluids flows with different chemical compositions. The $\mathrm{K}$-Ar data of finer $<0.05 \mu \mathrm{m}$ illite separates confirm two crystallization events at $179.4 \pm 4.5$ and 149.4 \pm 2.5 Ma during the Early and Late Jurassic. The slightly coarser fractions contain also earlier crystallized or detrital K-bearing minerals characterized by lower $\delta^{18} \mathrm{O}$ values. The $\delta^{18} \mathrm{O}$ of the finest authigenic illite separates tends to decrease slightly with depth, from $18.2( \pm$ $0.2)$ to $16.3( \pm 0.2) \%$, suggesting different but contemporaneous crystallization conditions deeper in the section.

The illite platelets and filaments crystallized in changing physical-chemical crystallization conditions induced by fluids flows through the host-rock pore system. These 
flow events were probably driven by repetitive rifting episodes of the North Atlantic Ocean, although located several hundreds kilometers away from eastern Paris Basin, and/or by fracturing events in the nearby basement of the Vosges Massif. Complex relationships between geodynamical events, thermal anomalies, and advective fluids confirm that remote tectonic activities can impact quiescent basins, even if located far from tectono-thermal activities, by discrete and long-distance fluid flows.

Keywords: Illite nanometric crystals, $\mathrm{K}-\mathrm{Ar}$ and $\mathrm{Rb}-\mathrm{Sr}$ dating, oxygen isotope tracing, rareearth element distribution, Triassic sandstones, eastern Paris Basin

\section{Introduction}

Sediment petrophysical characteristics are of critical importance for evaluation of natural energy resources and geological storage potentials of varied types of waste in sedimentary basins. The porosity/permeability properties of sedimentary reservoirs strongly depend on the intensity of their cementation, with sandstones usually displaying variable reservoir qualities that depend on the type, extent, origin and timing of the cementation episode(s) (Worden and Morad, 2000; Burley and Worden, 2003). Authigenic illite is known to reduce dramatically rock porosity, together with quartz and calcite, especially when consisting of filamentous particles (Macchi, 1987; Worden and Morad, 2003). Such illite either results from progressive conversion of illite-smectite mixed layers (labeled I-S hereafter; Inoue et al., 1987; Velde and Renac, 1996) monitored by K supply from either dissolution of K-bearing micas or feldspars during burial diagenesis, or interaction with longdistance migrating fluids of varied origins (Small et al., 1992; Lanson et al., 1996; Schlegel et 
al., 2007; Cathelineau et al., 2012). In the latter case, the reaction pathway leading to concomitant alteration of detrital grains and crystallization of authigenic minerals, and identification of the physical-chemical characteristics of the parent-fluid interactions are challenging to constrain (Lanson et al., 2002; Clauer and Lerman, 2012).

The present study focuses on physical and chemical aspects of the post-deposition history of Lower-Triassic sandstones from eastern Paris Basin. This geographic area has been investigated since 1995 by ANDRA (Agence Nationale pour la Gestion des Déchets Radioactifs), the French National Radioactive Waste Management Agency, for potential longterm geological repository of nuclear waste within the Callovian-Oxfordian claystone strata. As an identification step of the appropriate long-term storage qualities of the host rocks, and by extension of the whole regional context, a 2000-m deep borehole was drilled in 2009 close to the ANDRA underground research laboratory to check which type of regional aquifers are hosted by the underlying Lower-Triassic sandstones, and at which geothermal potential (Fig. 1; Landrein et al., 2013). Surprisingly, these Triassic sandstones contain abundant, widespread platy and filamentous illite, despite having only been buried to low depth $(<2500$ m) and subjected to low temperatures $\left(<100{ }^{\circ} \mathrm{C}\right.$; Blaise et al., 2013). To understand how and when illite precipitated in such conditions, nanometer-sized sub-fractions that are considered to consist of nucleating and initially growing illite crystals (Nadeau et al., 1984), were extracted for determination of their elemental and oxygen isotope compositions, and dated by the $\mathrm{K}-\mathrm{Ar}$ and $\mathrm{Rb}-\mathrm{Sr}$ methods to differentiate chemically the two morphologies and constrain their crystallization episode(s). Complementary to the routine X-ray diffraction (XRD) and wet-chemical analysis, petrographic and chemical information was obtained by optical (OM), scanning electron (SEM) and transmission electron (TEM) microscopy, and by electron dispersive spectrometry coupled to a transmission electron microscope (TEM-EDS).

\section{Geological setting and sample description}


The sedimentary Paris Basin is bound by uplifted crystalline massifs to the North, the West, the East and in the center, and by major tectonic structures, such as the Variscan thrust front to the North and the Tertiary Upper-Rhine Graben to the East (Mégnien, 1980). It underwent several periods of tectonic activity with local faulting and large-scale buckling that influenced the general sedimentation pattern (Brunet, 1980; Curnelle and Dubois, 1986; Guillocheau et al., 2000). Rifting processes started to the East with a general collapse of the Hercynian Massif during the Late Carboniferous to Permian time, followed by a westward shift of the subsidence towards the present-day centre of the basin during Late Triassic (= Carnian; Le Roux, 1980; Perrodon and Zabek, 1991). Thermal subsidence controlled the evolution of the basin at least until Early Cretaceous. Two emergence stages associated with erosion and alteration were identified at that time (Quesnel, 2003) as a result of both an eustatic sea-level drop and a distant influence of rift shoulder uplifts due to North-Atlantic rifting (Mégnien, 1980; Ziegler, 1990). Both episodes induced unconformity of the Late Cretaceous chalk overlying the Ardennes and Armorican crystalline basements. After sedimentation of the Upper Cretaceous, the eastern part of the basin emerged, was subjected to weathering and erosion that induced progressive exhumation of the underlying Jurassic carbonates that outcrop presently in the study area.

Six core samples of the EST433 well that was drilled into the Lower Triassic (Bourquin et al., 2006) next to the ANDRA Underground Research Laboratory were selected at depths between 1825 and 1999 m (Table 1; Fig. 1; Landrein et al., 2013). The shallowest sample at $1825 \mathrm{~m}$ is representative of the Muschelkalk (Middle Triassic), whereas the five others range from Middle to Upper Buntsandstein (Lower to Middle Triassic). Except the conglomerate facies at $1999 \mathrm{~m}$, all samples are fine- to coarse-grained sandstones. The rocks are rather unconsolidated, early mature (Ro $=0.75 \%$; Blaise et al., 2011) and free of visible hydrocarbon impregnation. 


\section{Analytical procedure}

The cores were observed from macroscopic to microscopic scale. Scanning (SEM) and transmission (TEM) electron microphotographs, and electron dispersive spectra with electron diffraction patterns (TEM-EDS) were obtained on powder samples dispersed in ethanol and deposited on a micro grid (Formvar/Carbon 300 Mesh Ni, Agar Scientific). The electron microscope was operated at $200 \mathrm{kV}$, equipped with a $\mathrm{Si}-\mathrm{Li}$ detector and $\mathrm{Li}$ super ultra-thin windows. Relative proportions of $\mathrm{Si}, \mathrm{Al}, \mathrm{Fe}, \mathrm{Mg}, \mathrm{Na}, \mathrm{Ca}, \mathrm{K}, \mathrm{Ti}$, and $\mathrm{S}$ were determined by the EDS technique. Structural formulae were calculated on the basis of eleven oxygen molecules per half unit cell. The tetrahedral layer was assumed to be filled with $\mathrm{Si}_{(4-\mathrm{x})}$ and $\mathrm{Al}_{\mathrm{x}}$ atoms (noted $\mathrm{Al}^{(\mathrm{IV})}$ ), and the octahedral layer with $\mathrm{Fe}, \mathrm{Mg}$ and the left-over $\mathrm{Al}^{(\mathrm{VI})}$, Fe being considered to be $100 \% \mathrm{Fe}^{(\mathrm{III})}$ without available information on the Fe oxidation-reduction conditions. The data of several reference clay minerals were added to the diagrams to represent the endmembers of potential crystal-chemical modifications (Kostov, 1968; Caillère et al., 1982).

The selected sandstone cores were first reduced into $\sim 1 \mathrm{~cm}^{3}$ chips and then disaggregated gently by using a repetitive freeze and thaw technique to avoid over-grinding of the framework minerals (e.g., Liewig et al., 1987). The slurries were treated with a dilute sodium-acetate buffer, sodium dithionite and hydrogen peroxide to remove the soluble mineral phases and organic matter from illite matrix (Jackson, 1975). The $<2 \mu \mathrm{m}$ size fractions were then separated by sedimentation following Stokes' law, and the $<0.2 \mu \mathrm{m}$ size fractions by high-speed centrifugation. The additional ultra-fine fractions $(<0.02,0.02-0.05$, $0.05-0.1,0.1-0.2 \mu \mathrm{m})$ were obtained by subjecting them first to an extensive dilution of $1 \mathrm{~g} / 40 \mathrm{~L}$ in deionized water to ensure "infinite" osmotic swelling by breaking the smectite interlayers of the I-S. Then, the nanometric size fractions were separated successively using a continuous-flow high-speed centrifuge, and were recovered from diluted fluids by 
flocculating the suspended matter with $\mathrm{NaCl}(1 \mathrm{M})$. Finally, the excess of reagent was removed by dialysis and centrifugation ( rodo et al., 1992). The sub-fractions smaller than $0.1 \mu \mathrm{m}$ were then analyzed by X-Ray diffraction (XRD) for their mineralogical composition, by wet chemistry for their major, trace and rare-earth elements (REE), by gas massspectrometry for their oxygen isotope composition. They were also dated by the K-Ar and RbSr methods.

The major elements were analyzed by inductively coupled plasma-atomic emission spectrometry (ICP-AES; Jobin Yvon 124) and the trace elements including the REEs by inductively coupled plasma-mass spectrometry (ICP-MS; Thermo-Electron PQ2), both following the procedure of Samuel et al. (1985). The overall analytical accuracy of the method was controlled periodically by measuring the glauconite (GL-O) and basalt (BE-N) geostandards (Govindaraju, 1994) that provided an analytical precision of $\pm 2.5, \pm 5$ and \pm $10 \%$, for respectively the major-, trace- and REE contents. The REE concentrations were normalized relative to the Post-Archean Average Shale (PAAS) reference (Taylor and McLennan, 1985), because of a similar sedimentary origin, and therefore for an easier control of the potential REE fractionations relative to a constant initial distribution. They were also compared to the REE contents of the NASC for further control (on the basis of the compilation by Piper and Bau, 2013), but not pictured as the data were consistently similar. The REE contents of leachates obtained by gentle leaching of the nanometric fractions were very low. To constrain best the potential erratic analytical uncertainty, they were duplicated and one set of each was normalized to the corresponding untreated fractions of samples EST1 and EST-2, as detailed in a further section.

For determination of their $\delta^{18} \mathrm{O}$ values, the nanometric size fractions were dehydrated under vacuum at $150{ }^{\circ} \mathrm{C}$ during 2 min plus the duration of the temperature increase and decrease from and to the room temperature. They were then allowed to react with $\mathrm{BrF}_{5}$ at 670 ${ }^{\circ} \mathrm{C}$ overnight in Ni tubes following Clayton and Mayeda's (1963) method. The liberated $\mathrm{O}_{2}$ 
was converted into $\mathrm{CO}_{2}$ by reaction with hot graphite. Isotopic analyses were carried out as $\mathrm{CO}_{2}$ on a gas mass spectrometer (VG Sira 10 or Optima). Systematic duplication of sample analysis and repeated analyses of an internal standard (granite A1113) and the NBS28 reference allowed estimation of the analytical uncertainty at $\pm 0.20 \%$. Results are reported using the conventional delta $(\delta)$ notation vs. V-SMOW.

The nanometric size fractions were also fused under vacuum in a high-frequency furnace coupled to a glass line, and the noble gases purified and analyzed on a static gas mass spectrometry following Bonhomme et al. (1975), with preheating of the powders at $80{ }^{\circ} \mathrm{C}$ under vacuum for at least $12 \mathrm{hr}$ to remove the potential atmospheric Ar adsorbed on the mineral particles. The accuracy of the results and the reproducibility of the procedure were controlled by periodic measurement of the glauconite (GL-O) international standard and the atmospheric Ar, as well as of the residual blank of the extraction line coupled to the mass spectrometer (VG Micromass 1000). During the study, the radiogenic ${ }^{40} \mathrm{Ar}$ of the GL-O standard amounted $24.38 \pm 0.10(2 \sigma) \times 10^{-6} \mathrm{~cm}^{3} / \mathrm{g}$ for four independent determinations, and the ${ }^{40} \mathrm{Ar} /^{36} \mathrm{Ar}$ ratio of the atmospheric Ar was at $294.9 \pm 0.6(2 \sigma)$ for six determinations. The recommended values being respectively $24.85 \pm 0.24 \times 10^{-6} \mathrm{~cm}^{3} / \mathrm{g}$ for the amount of radiogenic ${ }^{40} \mathrm{Ar}$ of the standard (Odin et al., 1982), and $298.6 \pm 0.4$ for the atmospheric ${ }^{40} \mathrm{Ar}{ }^{36} \mathrm{Ar}$ ratio (Lee et al., 2006), the analyzed values appeared internally consistent and close enough to the theoretical ones to not apply discrimination corrections to the individual determinations. The amount of the ${ }^{40} \mathrm{Ar}$ in the blank of the mass spectrometer and the coupled extraction line never exceeded $1 \times 10^{-8} \mathrm{~cm}^{3}$. The $\mathrm{K}$ contents were determined by flame spectrophotometry with the same reproducibility than that given above for all major elements at $2.5 \%$, despite further constrained by a supplementary analysis, between two successive samples, of a standard with a $\mathrm{K}$ content close to those of the two framing samples. The overall analytical uncertainty of the K-Ar data results from an error propagation calculation standardized a long time ago by Dalrymple and Lanphere (1969) for this method and 
generalized by Roddick (1987). The calculation integrates an average error of $2.5 \%$ for the K content, $0.05 \%$ and $1.0 \%$ for respectively the ${ }^{40} \mathrm{Ar} /{ }^{38} \mathrm{Ar}$ and ${ }^{38} \mathrm{Ar} /{ }^{36} \mathrm{Ar}$ ratio, and $0.1 \%$ for the spike calibration. The usual decay constants were used for the age calculation (Steiger and Jäger, 1977) with an overall analytical precision better than $2.5 \%$, the final uncertainty of the individual ages including that of the sample weighing.

The fractions of the two upper EST-1 and EST-2 sandstones were also analyzed for their $\mathrm{Rb}-\mathrm{Sr}$ isotope characteristics before and after gentle acid leaching. The purpose was not a $\mathrm{Rb}-\mathrm{Sr}$ dating exercise, but an attempt to control the potential contemporaneous crystallization of the illite-rich crystals and the intimately mixed soluble components. Theoretically, if the Rb-Sr "ages" calculated on the basis of "duochrons" obtained from untreated fractions and equivalent leachates are reasonably similar to those of the corresponding K-Ar ages, the soluble and illite components of each fraction are probably contemporaneous, having interacted with the same fluids. Alternatively, different $\mathrm{Rb}-\mathrm{Sr}$ and K-Ar "ages" suggest non-contemporaneous crystallization of the illite crystals and soluble components. In fact, simultaneous analysis of the untreated, leached and insoluble fractions of each nano-sized fraction would have been even more appropriate for this approach. Unfortunately, the recovered amounts of powder for each size fraction of the selected samples were not enough to run all complementary analyses. The technical aspect included leaching of the adsorbed elements from particle surface and dissolution of the soluble components with dilute HAc $(1 \mathrm{M})$ during $30 \mathrm{~min}$ at room temperature increased by the time for centrifugation and slowing down of the rotor. The method follows Clauer (1982) with special attention not to use the brake of the ultracentrifuge after rotation, to avoid turbulences and therefore renewed dispersion of the finest nanometric particles back into the supernate. In this respect, it is probably appropriate to recall that gentle acid leaching, as that used here, does not affect the $\mathrm{Rb}-\mathrm{Sr}$ and $\mathrm{K}-\mathrm{Ar}$ isotopic systems of clay particles regardless of type, size or crystalline degree (Clauer et al., 1993). Also to be remembered is the fact that interpretation of the lines 
in ${ }^{87} \mathrm{Sr} /{ }^{86} \mathrm{Sr}$ vs. $1 / \mathrm{Sr}$ or ${ }^{87} \mathrm{Sr} /{ }^{86} \mathrm{Sr}$ vs. ${ }^{87} \mathrm{Rb} /{ }^{86} \mathrm{Sr}$ diagrams strictly depends on the studied material (e.g., Clauer and Chaudhuri, 1995): for instance, a geologically meaningful isochron can only be claimed if the analyzed material is fully authigenic. If it is not the case, the lines yield meaningless slopes representing mixtures of components of varied origins (Clauer et al,, 2011). To be reiterated also is the fact that the data were only generated from "duochrons", the results being evaluated with special care and an increased analytical uncertainty.

After acid digestion of the untreated aliquots and evaporation of the acid leachates, $\mathrm{Sr}$ was separated by resin chromatography and analyzed by solid-source mass-spectrometry for its isotopic composition. The Sr separation and purification was obtained on Eichrom Sr-resin following Pin et al. (2003). The purified $\mathrm{Sr}$ was loaded on a Ta-filament, and the ${ }^{87} \mathrm{Sr} /{ }^{86} \mathrm{Sr}$ isotopic ratio measured by thermal ionization mass spectrometry (Finnigan Triton TI). About 100 ratios were measured for each aliquot to ensure the best analytical error depending on the available amount of analyzed aliquot. The external reproducibility of the isotopic measurements was controlled by analysis of the NBS987 standard that provided a mean value of $0.710258 \pm 2.2 \times 10^{-6}(2 \sigma)$. The $\mathrm{Rb}$ and $\mathrm{Sr}$ contents of the leachates were determined by ICP-MS with a reproducibility of 5\%, together with the major-, trace- and REEs. The Rb-Sr data were calculated with the usual decay and fractionation constants (Steiger and Jäger, 1977).

\section{Results}

\section{Petrography}

Albite and K-feldspar overgrowths on Na- and K-feldspar grains (Fig. 2A), as well as quartz overgrowths on detrital quartz grains (Fig. 2C, B), and probable sub-synchronous crystallizations of quartz and K-feldspar (Fig. 2B) are visible by OM observations under 
polarized light of $30 \mu \mathrm{m}$-thick thin-sections. SEM observations show euhedral, authigenic quartz and feldspar habitus, such as bi-pyramidal quartz overgrowths embedding entirely the detrital quartz grains in some instances, as well as adularia crystallization on detrital, partly dissolved K-feldspar crystals (Fig. 3A, B, C). The overgrowth of the quartz and K-feldspar grains is well developed and preserved, and looks like sub-synchronous. Newly formed illite is widespread, displaying varied morphologies and growth features on quartz and adularia, therefore postdating their crystallization. As the samples were not grinded on purpose, the origin of the quartz grains in almost all size fractions can be considered to be authigenic, because of their size but also because of their euhedral shape. When platy and hexagonal, illite displays mainly epitaxic overgrowths on authigenic or older, either earlier crystallized within the host rocks or strictly detrital K-feldspars (Fig. 3C), whereas filamentous illite crystallized preferentially within the pore space (Fig. 3E, F). Sometimes, filamentous illite occurs also as epitaxic crystals along lateral faces of previous hexagonal illite plates (Fig. 3D). Chlorite and kaolinite crystals, either of detrital or early diagenetic origin, were also identified. Kaolinite occurs rarely as "blocky" dickite-like crystals. As euhedral framboids or single crystals, authigenic pyrite is closely associated with macerals, illite and partly dissolved detrital feldspar grains (Fig. 3G, H), giving localized greenish reduced micro-volumes.

These observations have been summarized into successive diagenetic steps that are consolidated by appended arguments such as crystallization timing and temperatures discussed in later sections (Fig. 5). Noteworthy and conversely to general claims and published models (e.g., Lanson et al., 2002), illite did not result here from dissolution of kaolinite-dickite, because: (1) remnants of such kaolin minerals were only observed in the deepest EST-6 conglomeratic sample buried at $1999 \mathrm{~m}$, none being detected in the other samples, and (2) quartz and K-feldspar crystallization occurred before illitization, consuming $\mathrm{Si}$ and $\mathrm{Al}$ either released from altering kaolinite-dickite association when occurring, or as dissolved solutes in the migrating fluids. Also to be mentioned is the fact that these 
mineralogical and petrographical features are not unique; they were also reported at a larger regional scale in equivalent stratigraphic units at Haut-du-Roc near Remiremont about 150 $\mathrm{km}$ to the ESE of the drill-hole location (Fig. 1), and in Upper-Triassic sandstones buried at similar depths in the south-central Paris Basin (Mossmann et al., 1992; Clauer et al., 1995).

\section{Clay Mineralogy}

Examined by XRD, the nano-fractions $(<0.02,0.02-0.05,0.05-0.1 \mu \mathrm{m})$ consist mostly of illite at all sizes, often mixed with minor amounts of I-S detectable by a slight shift of the 10-Å illite peak after ethylene-glycol impregnation and chlorite-smectite (labeled C-S) mixed layers, chlorite and accessory minerals such as quartz and K-feldspar (Table 1). Most of these non-illitic minerals are difficult to quantify by XRD due to their low $(<3-5 \%)$ contents. Chlorite was identified in almost all studied samples, whereas kaolinite is restricted to the already mentioned deeper EST-6 conglomerate. Minute amounts of C-S were detected in the shallowest EST-1 sample. The abundance of quartz consistently decreases with particle size in all samples, confirming an authigenic origin for, at least, the finest grains. If detrital, its contents should have increased instead. Minute amounts of K-feldspar were also detected in three coarser fractions of two samples (Table 1).

\section{Clay Chemistry}

TEM-EDS crystal-chemical in situ data show that the two illite lath/fiber and platelet morphologies correspond at least to two different populations. Their compositions are typical of illite-rich I-S close to pure illite. However, slight chemical differences confirm the two types of particles: (1) the interlayer charge is between 0.7 and 0.9 in the laths/fibers and between 0.8 and 1.0 in the plates, and (2) this difference in the interlayer corresponds to a higher Si content in the laths than in the platelets (Fig. 6A). There is also a marked difference in the $\mathrm{Fe} / \mathrm{Fe}+\mathrm{Mg}$ ratio, which is significantly higher in the platelets than in the laths (Fig. 6B). 
The Fe and $\mathrm{Mg}$ concentrations do not vary significantly as a function of grain size, but the laths contain systematically more Mg than the platelets (Fig. 6C). In summary, the calculated average structural formulae are:

$$
\left(\mathrm{Si}_{3.31} \mathrm{Al}_{0.69}^{(\mathrm{IV})}\right)\left(\mathrm{Al}_{1.74}^{(\mathrm{VI})} \mathrm{Mg}_{0.08} \mathrm{Fe}_{0.13}\right) \mathrm{K}_{0.92} \mathrm{O}_{11}(\mathrm{OH})_{2}
$$

for the hexagonal platelet-shaped illite, and

$$
\left(\mathrm{Si}_{3.61} \mathrm{Al}^{(\mathrm{IV})}{ }_{0.39}\right)\left(\mathrm{Al}^{(\mathrm{VI})}{ }_{1.58} \mathrm{Mg}_{0.22} \mathrm{Fe}_{0.13}\right) \mathrm{K}_{0.81} \mathrm{O}_{11}(\mathrm{OH})_{2}
$$

for the filaments. The observed changing chemical compositions, especially in the K content, suggest different crystallization conditions for the two illite types.

The total concentrations of the major elements are consistently within 98.83 and $101.08 \%$ of oxides and the loss of ignition (LOI; Table 2). The highest LOI is systematically for the intermediate $0.02-0.05 \mu \mathrm{m}$ fractions, which suggests that they contain higher amounts of volatiles. The contents are consistent with the XRD mineral identification: $\mathrm{K}$ and $\mathrm{Al}$, for instance, are mainly controlled by illite and identified I-S. The highest Al concentrations are found in the deeper EST-6 sample at 1999 m, where they reflect addition of kaolinite. The large range of Si contents is due to variable amounts of authigenic and possibly detrital quartz. $\mathrm{Mg}$ is positively correlated with $\mathrm{Fe}$, in relation with chlorite and/or C-S. Phosphate concentrations are rather low, but the positive correlation between $\mathrm{Ca}$ and $\mathrm{P}(\mathrm{R}=0.94$ for $\mathrm{n}=18$ ) suggests minute amounts of apatite that were observed independently by SEM (Ploquin, 2011). The $\mathrm{Sr}$ and $\mathrm{Rb}$ contents tend to be higher in the coarser $0.05-0.01 \mu \mathrm{m}$ fractions, being possibly linked to the presence of feldspar. Indeed, K-feldspar was abundant enough to be detected by XRD in the coarser fractions of samples EST-3 and EST-5 (Table $1)$. 
Except for the deeper EST-6 conglomerate, the PAAS-normalized REE patterns of the nanometric illite are consistent among the size fractions of the other samples (Fig. 7), with an enrichment of the middle REEs (MREE) leading to "bell-shaped" patterns (e.g., Zwingmann et al., 1999). The three fractions of the EST-6 conglomerate display markedly different REE patterns with a regular increase in the normalized MREE and HREE concentrations. In spite of differences in absolute concentrations of the REEs, the distribution patterns remain broadly consistent among the size fractions of the selected samples.

The chemical data of the dilute acidic leachates of the nanometric illite fractions from two upper EST-1 and EST-2 samples were duplicated for most studied size fractions to consolidate the analytical reproducibility. The leachates consist essentially of $\mathrm{Ca}$ and $\mathrm{K}$ or $\mathrm{Na}$ (Table 3). As stated above, all samples were initially subjected to a Jackson (1975) treatment to remove the adsorbed chemical elements on the silicate particles, as well as the associated soluble mineral phases and organic matter. Therefore, the elements released by the dilute-acid leaching were constitutive of soluble components that escaped the initial treatment, trapped and somehow protected within illite inter-crystalline domains. Inaccessible to the initial reagents, they were leached later due to the further size reduction of the illite particles that induced an easier access to that intra-crystalline domain. The Ca contents of the EST-1 leachates correlate with high $\mathrm{Mg}$ contents, suggesting the occurrence of $\mathrm{Ca}$ - and $\mathrm{Mg}$ carbonates, whereas the carbonate of sample EST-2 is Mg-depleted. The high $\mathrm{Na}$ content probably relates to salt crystals that were observed independently by SEM. Noteworthy is also the $\mathrm{P}$ content of sample EST-2 consistently increasing with increasing grain size and $\mathrm{Ca}$ content. The correlation between $\mathrm{Ca}$ and $\mathrm{P}(\mathrm{R}=0.48$ for $\mathrm{n}=18)$ points also to the occurrence of a soluble Ca-P phases of possible organic origin, which explains why they were dissolved by dilute acid, while apatite was not, and why the correlation coefficient between $\mathrm{Ca}$ and $\mathrm{P}$ was lower than for the untreated fractions, probably because $\mathrm{Ca}$ occurred also as a different soluble phase. 


\section{$\underline{R E E \text { characteristics of the soluble components (= leachates) }}$}

Duplication of some leaching experiments of the size fractions from two EST-1 and EST-2 samples shows that, except for the La content of the 0.05-0.1 and the Nd content of the 0.02-0.05 $\mu \mathrm{m}$ fraction of sample EST-2, the data reproducibility is analytically acceptable considering the very low measured amounts (Table 3). Relative to their corresponding untreated fractions, the REE distribution patterns of the leachates are of broadly similar shapes. With the exception of $\mathrm{Tm}$ and $\mathrm{Lu}$ for the leachate from $0.05-0.1 \mu \mathrm{m}$ fraction of sample EST-1, which contents are close to the analytical detection limit and therefore off the general trend, the patterns are all characterized by dissymmetric "bell-shaped" distributions with the maxima for Eu or its neighbor Gd (Fig. 8). In the detail, only the amounts of the REEs differ, those of the EST-1 size fractions ranging at about $1.5 \mu \mathrm{g} / \mathrm{L}$, whereas those of the EST-2 being higher at 8.5 to $26 \mu \mathrm{g} / \mathrm{L}$. The overall similar distribution patterns suggest a simultaneous precipitation for the leached soluble mineral phases from the same fluids, however at variable concentrations.

Interestingly, the tip of the shapes for the distribution patterns of the leachates is not systematically with Eu. If it is the case for the leachates from smallest $<0.02 \mu \mathrm{m}$ fractions, it is not for those from $0.02-0.05$ and $0.05-1 \mu \mathrm{m}$ fractions of the two samples, for which it is either Gd or even $\mathrm{Tb}$. The systematic strongly positive anomalies in Eu are signatures for the input of feldspars. Conversely, the Gd or Tb positive anomalies are basically unexpected in the mineral world, confirming that except for $\mathrm{Ce}$ and $\mathrm{Eu}$, which can occur either as tetra- or divalent configurations in addition to their usual trivalent configuration, all other REEs of mineral origin never yield such significant positive anomalies relative to the conventional standards (e.g., Taylor and McLennan, 1985). A straight interpretation for these abnormal Gd 
and/or $\mathrm{Tb}$ supplies might then relate to the occurrence of organic matter as Gd anomalies, at least, were reported in living plants at surficial conditions (e.g., Semhi et al., 2014).

\section{$\underline{\text { K-Ar data }}$}

The $\mathrm{K}_{2} \mathrm{O}$ concentrations from $3.59 \%$ in the $0.05-0.1 \mu \mathrm{m}$ fraction of sample EST-6 to $6.54 \%$ in the $0.02-0.05 \mu \mathrm{m}$ fraction of sample EST-2 (Table 4) are due to variable dilution of illite and I-S by K-free minerals (mainly quartz). However, a straight correlation among the determining chemical elements is difficult to obtain. The amount of radiogenic ${ }^{40} \mathrm{Ar}$ ranges from $84.2 \%$ to $94.6 \%$, indicating good analytical conditions with limited atmospheric contamination, which in turn favors a more accurate evaluation of the initial ${ }^{40} \mathrm{Ar} /{ }^{36} \mathrm{Ar}$ ratio trapped in the authigenic illite crystallites.

The seventeen individual $\mathrm{K}-\mathrm{Ar}$ ages range from $145.7 \pm 3.0 \mathrm{Ma}$ to $217.3 \pm 4.5 \mathrm{Ma}$. Those of the finest $<0.02$ and $0.02-0.05 \mu \mathrm{m}$ fractions from samples EST-2, EST-4 and EST-5 are consistent, as well as the finest and coarsest fractions of sample EST-6, with data ranging narrowly from $145.7 \pm 3.0$ to $152.7 \pm 3.2 \mathrm{Ma}$, which is almost within analytical uncertainty. The data of the same $<0.02$ and $0.02-0.05 \mu \mathrm{m}$ fractions of samples EST-1 and EST-3 and of

the coarser $(0.05-0.1 \mu \mathrm{m})$ fractions of these five samples are scattered between $168.1 \pm 3.5$ and $217.3 \pm 4.5 \mathrm{Ma}$, again with the exception for the coarser fraction of sample EST-6 (Table 4). Noteworthy about this set of data is the narrow range of the finest $<0.02$ and $0.02-0.05 \mu \mathrm{m}$ fractions of the samples EST-1 and EST-3 that range narrowly again between $173.9 \pm 3.7$ to $184.7 \pm 3.8 \mathrm{Ma}$

Before evaluating the set of K-Ar data, it is probably appropriate to recall that the coarsest $0.05-0.1 \mu \mathrm{m}$ and one intermediate $0.02-0.05 \mu \mathrm{m}$ fraction of samples EST-3 and EST5 contain identified K-feldspar (Table 1). An age bias for these three size fractions is, therefore, expectable. The geological interpretation of the entire set of K-Ar ages was first 
based on a preliminary statistical evaluation of their scatter by the software AGEDISPLAY that was initially conceived for examination of $\mathrm{U}-\mathrm{Pb}$ ages (Sircombe, 2004). It allows calculation of binned frequency histograms and probable density distributions based on the assessment of the efficiency of bin widths. Its limitation is in the evaluation of the analytical uncertainty of the integrated data, the sample distribution being estimated on the basis of the age values alone. As such an option of discarding the individual analytical errors may potentially lead to misinterpretations, only the ages obtained from narrow Gaussian width distribution peaks have been evaluated, which includes all available data in the present case. Selection of a bin width close to the individual analytical errors at 10 Ma shows a histogram pattern with two groups of ages at 140-150 Ma and at $180 \mathrm{Ma}$ amounting 12 of the 17 analyses, whereas the independently calculated probability density distribution outlines two representative data concentrations at 149 and 179 Ma with respective probabilities of 2.8 and $1.3 \%$ (Fig. 9A).

This statistical evaluation has been complemented, especially for a check of the analytical uncertainty, by a correlation study of the ${ }^{40} \mathrm{Ar} /{ }^{36} \mathrm{Ar}$ and ${ }^{40} \mathrm{~K} /{ }^{36} \mathrm{Ar}$ ratios from the two sets of eight and four size fractions outlined by the AGEDISPLAY software. The ${ }^{40} \mathrm{Ar}{ }^{36} \mathrm{Ar}$ and ${ }^{40} \mathrm{~K} /{ }^{36} \mathrm{Ar}$ ratios of the whole set of data were determined with individual uncertainties $( \pm 2 \sigma)$ between 1.03 and $2.92 \%$ for the former ratio, and between 2.31 and $3.38 \%$ for the latter (Table 4). The correlation coefficients of the two trends are at $0.998(n=8)$ and $0.973(n=4)$, respectively. The data points of the two smallest $(<0.02$ and $0.02-0.05 \mu \mathrm{m})$ fractions of the samples EST-2, EST-4 and EST-5, and the smallest $(<0.02 \mu \mathrm{m})$ and coarsest $(0.05-0.1 \mu \mathrm{m})$ fractions of sample EST-6 for which the intermediate $(0.02-0.05 \mu \mathrm{m})$ fraction could not be analyzed because of lack of powder, plot along a lower array that yields an age of $149.4 \pm 2.5$ Ma in an isochron diagram, aided by an isoplot calculation (Ludwig, 2001; Fig. 9B). Among the data points dispersed above this array, those of the two smallest fractions of samples EST1 and EST-3 fit the second slightly steeper array with an average age of $179.4 \pm 4.5$ Ma based 
on the same calculation. Interestingly, the remaining dispersed data points with scattered older ages are only of the coarser $0.05-0.1 \mu \mathrm{m}$ fractions of five samples, which suggests the occurrence of K-bearing minerals, probably the K-feldspars identified by XRD, that either crystallized earlier or are of detrital origin at this grain size. The initials of the two arrays cut the ${ }^{40} \mathrm{Ar} /{ }^{36} \mathrm{Ar}$ ordinates at $277 \pm 85$ and $237 \pm 110$, respectively, which is within analytical uncertainty with the atmospheric value of $298.6 \pm 0.3$ (Lee et al., 2006).

A value of 0.87 for the Mean Square Weighted Deviates (MSWD), which is a valuable control to evaluate the analytical database of an isochron plot, is obtained for the lower array, whereas that of the steeper array is less constrained at 2.5 . To be identified as isochrons, it is basically required that the MSWDs of such arrays yield a statistical value of 1.0 or less. However, due to the limited number of samples of many available datasets, the MSWDs are often beyond 1.0, which incited Brooks et al. (1972) to suggest that 2.5 is an acceptable cutoff for a definition in favor of a geologically-meaningful isochron. This is the case here, a general discussion being scheduled in a further section on the basis of a comparison of the ages with the mineralogical, chemical and oxygen isotopic data of the illite separates, and with the known regional evolution of the Triassic sandstones from Paris Basin.

In summary, the statistical examination of the K-Ar data points to two age peaks at about 179 and $149 \mathrm{Ma}$, the second being better constrained. These two statistical ages are confirmed by isochron trends at $149.4 \pm 2.5$ and $179.4 \pm 4.5 \mathrm{Ma}$, with initial ${ }^{40} \mathrm{Ar} /{ }^{36} \mathrm{Ar}$ within analytical uncertainty with the atmospheric ${ }^{40} \mathrm{Ar} /{ }^{36} \mathrm{Ar}$ and MSWDs below 2.5. It can therefore

be assumed that these two ages record two geologic events, with a less constrained database for the older than the younger episode.

\section{$\underline{\text { Rb-Sr data }}$}

$\mathrm{The} \mathrm{Rb}$ and $\mathrm{Sr}$ contents of the dilute-acid leachates from the three size fractions of samples EST-1 and EST-2 range from 0.4 to $1.2 \mu \mathrm{g} / \mathrm{g}$, and from 2.3 to $18.8 \mu \mathrm{g} / \mathrm{g}$, respectively 
(Table 5). To be mentioned is the duplicate $\mathrm{Sr}$ content of the $0.02-0.05 \mu \mathrm{m}$ fraction of sample EST-2 that ends outside the analytical uncertainty. The contents of the untreated fractions are consistently higher for $\mathrm{Rb}$ (163 to $251 \mu \mathrm{g} / \mathrm{g}$ ) than for $\mathrm{Sr}\left(28.5\right.$ to $114 \mu \mathrm{g} / \mathrm{g}$ ). $\mathrm{The}^{87} \mathrm{Sr} /{ }^{86} \mathrm{Sr}$ ratios of the leachates range from $0.713651\left( \pm 26 \times 10^{-6}\right)$ to $0.714428\left( \pm 66 \times 10^{-6}\right)$ in sample EST-1, and from $0.711307\left( \pm 14 \times 10^{-6}\right)$ to $0.712906\left( \pm 15 \times 10^{-6}\right)$ in sample EST-2. The same ratios of the untreated fractions are significantly higher, from $0.744088\left( \pm 11 \times 10^{-6}\right)$ to $0.748169( \pm$ $\left.80 \times 10^{-6}\right)$, and from $0.725047\left( \pm 16 \times 10^{-6}\right)$ to $0.729824\left( \pm 10 \times 10^{-6}\right)$, respectively. Plotted into a ${ }^{87} \mathrm{Sr} /{ }^{86} \mathrm{Sr}$ vs. ${ }^{87} \mathrm{Rb} /{ }^{86} \mathrm{Sr}$ isochron diagram, the data points fit three lines for the three fractions of sample EST-1 that converge towards a common initial ${ }^{87} \mathrm{Sr} /{ }^{86} \mathrm{Sr}$ ratio of about $0.7131 \pm 0.0002$ with slopes giving ages within analytical uncertainty of $148 \pm 8$ Ma for the $<0.02 \mu \mathrm{m}$ fraction, $134 \pm 7 \mathrm{Ma}$ for the $0.02-0.05 \mu \mathrm{m}$ fraction, and a higher age of $176 \pm 10 \mathrm{Ma}$ for the $0.05-0.1$ $\mu \mathrm{m}$ fraction, all being calculated with only two data points (Fig. 10). The data display for the sample EST-2 is different with three sub-parallel lines giving the same age at $148 \pm 8$ Ma but with an initial ${ }^{87} \mathrm{Sr} /{ }^{86} \mathrm{Sr}$ ratio of $0.7108 \pm 0.0001$ for the $<0.02 \mu \mathrm{m}$ fraction, $0.7116 \pm 0.0002$ for the $0.02-0.05 \mu \mathrm{m}$ fraction, and $0.7125 \pm 0.0001$ for the $0.05-0.1 \mu \mathrm{m}$ fraction.

In summary, the $\mathrm{Rb}-\mathrm{Sr}$ ages are almost identical within analytical uncertainty for five of the six analyzed leachate-untreated couples. Noteworthy are also the initial ${ }^{87} \mathrm{Sr} /{ }^{86} \mathrm{Sr}$ ratios that are either identical for the three fractions of sample EST-1, or slightly decreasing with crystal size for sample EST-2. Except for the two finest fractions of sample EST-2, the Rb-Sr ages calculated by combining the leachates and untreated aliquots are younger than the corresponding individual K-Ar ages, suggesting that the ${ }^{87} \mathrm{Sr} /{ }^{86} \mathrm{Sr}$ ratios of the leachates are not strictly in chemical equilibrium with those of the illite crystals. On the other hand, some of the $\mathrm{Rb}-\mathrm{Sr}$ ages of the leachate-untreated couples are close to the $\mathrm{K}$-Ar ages of either $149 \pm 3 \mathrm{Ma}$ or $180 \pm 5 \mathrm{Ma}$. 


\section{Oxygen isotope data}

Due to limited amounts of extracted clay-rich material, all the fractions of the samples EST-3 and EST-5 could not be analyzed for their oxygen isotope compositions. The $\delta^{18} \mathrm{O}$ values vary from $+14.9( \pm 0.2)$ to $+18.2( \pm 0.2) \%$ (V-SMOW; Table 4$)$. The coarser fractions of samples EST-3 and EST-5 display the lowest values, probably because of contamination by low- $\delta^{18} \mathrm{O}$ of high-temperature detrital K-feldspar detected by XRD analysis (Table 1) and whole-rock chemistry (Table 2). To be added is the fact that all separates contain also some quartz that could be of authigenic origin. For the finer fractions, the $\delta^{18} \mathrm{O}$ values broadly decrease with increasing depth from $+18.2( \pm 0.2)$ to $+16.3( \pm 0.2) \%$ (V-SMOW).

\section{Discussion}

\section{Significance of the mineral assemblages}

TEM observations of illite crystals corroborate the existence of two generations based on the particule morphology and K-Ar ages: (1) older sub-hexagonal crystals with euhedral shapes (Fig. 4E, F), and (2) younger, well-crystallized elongated laths often developed by epitaxy on hexagonal illite (Fig. 4A, B, C, D). These microscopic observations helped setting successive diagenetic alteration steps (Fig. 5). It might be recalled that: (1) illite could not result only from dissolution of kaolinite-dickite, because kaolin minerals were only observed in the deepest EST-6 sample and hexagonal kaolinite is basically not changing into filamentous illite, and (2) concomitant quartz and K-feldspar crystallization preceded illitization, as platy and filamentous illite particles were observed growing on authigenic quartz and K-feldspar grains. Noteworthy, these local mineralogical and petrographic features are not unique; they were also reported at a larger regional scale in nearby equivalent 
stratigraphic units at Niderviller and Haut du Roc on the western flank of the Vosges Massif (Fig. 1; Blaise, 2012), and Niedersteinbach (Tournier et al., 1999).

The paragenetic sequence observed by OM, SEM and TEM also required an opensystem behavior of the host rocks to allow migration of fluids, necessarily changing in chemical composition and temperature, in order to induce successive mineral crystallizations together with more or less extensive dissolutions (Fig. 5). However, a thermo-dynamic control of these variations is challenging, because drawing activity diagrams is especially difficult for illite at low temperature $\left(<100^{\circ} \mathrm{C}\right)$, because only I-S phases or identified illite with rather low interlayer occupancy are considered forming stable macroscopic mineral phases. The stability field of an illite with an interlayer charge higher than 0.85 cannot, therefore, be visualized in a $\mathrm{K}^{+} / \mathrm{H}^{+}$vs. $\mathrm{Na}^{+} / \mathrm{H}^{+}$diagram at crystallization temperatures of about $100^{\circ} \mathrm{C}$ (Yates and Rosenberg, 1996), while illite is likely stable at temperatures higher than $150-200{ }^{\circ} \mathrm{C}$. However, it can be stated, on the basis of OM (Fig. 2) and SEM observations (Fig. 3), that the initial episode is clearly characterized by a concomitant quartz and K-feldspar crystallization without illite. Quartz saturation resulted either from redistribution of silica due to pressure solution (Bjørlykke and Egeberg, 1993; Worden and Morad, 2000), although such a process is not intense in rocks with high permeability and limited compaction like here, or from changing pore-water temperature, fluid-cooling being the driving force for quartz oversaturation in open media. On the basis of a classic activity diagram in the K-Na-Si-(Al) system (Bowers et al., 1984), K-feldspar precipitation requires high $\mathrm{K}^{+} / \mathrm{H}^{+}$ratios, e.g. a neutral or slightly basic $\mathrm{pH}$. Such $\mathrm{pH}$ values correspond to solutions equilibrated with respect to carbonates that are abundant here in adjacent formations, together with a high $\mathrm{K}^{+}$activity that favors feldspar crystallization instead of phyllo-silicates, and high $\mathrm{K} / \mathrm{Na}$ ratios, albite overgrowths having only been observed in a few instances, despite probable high $\mathrm{Na}(\mathrm{Cl})$ contents of the fluids. 
Precipitation of illite after feldspars resulted necessarily from a significant change in the fluid chemistry, e.g. a drop in the $\mathrm{K}^{+} / \mathrm{H}^{+}$ratio that could have resulted from a drop in either $\mathrm{K}$ activity or $\mathrm{pH}$, therefore excluding concomitant precipitation of $\mathrm{K}$-feldspar and illite. Both, $\mathrm{K}$ and/or $\mathrm{pH}$ drop, can then be explained by supply of more dilute fluids, possibly from another reservoir. Clearly, none of these conditions favored precipitation of kaolinite or dickite that were observed in the deeper conglomerate, which occurrence has thus to be considered as detrital, unless it resulted from a progressive, burial-induced diagenesis in rock units that were not already invaded by migrating hydrothermal-type fluids. This hypothesis is not valid on the basis of the K-Ar ages from concomitant illite that obviously crystallized during fluid flow events. Alternatively, concomitant quartz and illite precipitation has been described in the basement rocks of the Rhine Graben at Soultz-sous-Forêt (Smith et al., 1998; Cathelineau and Boiron, 2010), where it is linked to mixing of brines issued from and equilibrated with Triassic formations. These fluids penetrated downwards, apparently with meteoric fluids that were identified in the basement rocks. Illite crystallization was, then, also favored by decreasing temperature and chlorinity after fluid mixing (Komninou and Yardley, 1997).

\section{Significance of the illite K-Ar ages}

Illitization is largely controlled by the K content of the host-rock pore waters, and was probably favored by rather low pHs in the sandstones (Lanson et al., 2002). It is often reported as resulting from either progressive K-fixation in a smectite-to-illite trend (e.g., Inoue et al., 1987), or as a direct mineral precipitation associated with concomitant alteration/dissolution of detrital K-bearing feldspar and micas (e.g., Schlegel et al., 2007; Brockamp et al., 2011). Systematic decrease of K-Ar dates with decreasing micrometric size fractions of clay-rich material has been often reported (e.g., Clauer et al., 1995; Zwingmann et al., 1999; Cathelineau et al., 2004; Sant'Anna et al., 2006), the older ages of the coarser size 
fractions being generally considered as reflecting contribution of detrital minerals that accumulated more radiogenic argon. Progressive dissolution of these detrital feldspar grains and mica flakes induces isotopic resetting that is dependent on the crystal size and the ambient temperature (Cathelineau et al., 2004). Separation of size fractions as small as possible is therefore recommended, especially of sandy but also of argillaceous sediments, as it minimizes contamination by coarser non- or partly-recrystallized K-bearing framework minerals (Clauer and Lerman, 2012). However, the correlative decrease of K-Ar age and crystal size also points to a long-term wisdom about increased "mechanical" release (= loss) of ${ }^{40} \mathrm{Ar}$ from crystallites becoming smaller. This wisdom was activated again recently by a molecular modeling of ${ }^{40} \mathrm{Ar}$ recoil in illite particles (Szcerba et al., 2015) without any experimental support for the offered theoretical interpretation of the ${ }^{40} \mathrm{Ar}$ loss. In fact, this advocated recoil due to decrease of crystallite size is clearly questionable on the basis of alkylammonium leaching of illite crystals, also of nanometric size. In this case, Clauer (2011) showed experimentally on the basis of such leaching protocol that di-octahedral illite crystallites, even as small as $<0.02 \mu \mathrm{m}$, do not lose "mechanically" ${ }^{40}$ Ar beyond analytical uncertainty.

The geological meaning of the K-Ar age at $179.4 \pm 4.5$ Ma being less constrained because of the limited number of data taken from a cloud of data points of coarser fractions, further information can be earned by comparing these K-Ar ages with the data obtained from mineralogical, chemical, isotopic and morphologic techniques on the same materials. As already stated, the coarser fractions yield older K-Ar ages than the finest ones except for the deeper EST-6 sample, even if not systematically the oldest (Table 4). The coarser fractions also give lower $\delta^{18} \mathrm{O}$ values than the finest ones except, again, for the same EST-6 sample. As K-feldspar was identified by XRD in the coarser fractions of the EST-3 and EST-5 samples (Table 1), it is clear that the ages older than $200 \mathrm{Ma}$ are geologically meaningless, due to an excess of radiogenic ${ }^{40} \mathrm{Ar}$ supplied by the feldspar grains, detrital or crystallized in situ earlier 
than the common age of about 180 Ma. However, no detrital minerals having been observed by OM or detected by XRD analysis in the three other EST-1, EST-2 and EST-4 samples, addition of authigenic illite that crystallized at a similar crystal shape during an earlier thermal episode appears more justified than a partial isotopic resetting of detrital mica or feldspar grains that would probably lead to more dispersed data than those obtained here. The narrow K-Ar ages of the coarser fractions of samples EST-2 and EST-4, for which the data points plot below the upper array in the isochron diagram (Fig. 9B) are more in favor of a limited addition of illite from 180-Ma generation than of detrital grains variably older than $180 \mathrm{Ma}$ that should naturally provide a larger dispersion. The K-Ar ages of the two finest fractions $(<0.02 \mu \mathrm{m}$ and $0.02-0.05 \mu \mathrm{m})$ being consistent with each other, as are their $\delta^{18} \mathrm{O}$ values (Table 4), suggest that they are free of any contamination by detrital or earlier crystallized K-bearing minerals. Interestingly, the finest $<0.02 \mu \mathrm{m}$ fractions of four samples yield older K-Ar ages than the corresponding coarser $0.02-0.05 \mu \mathrm{m}$ fractions, although within analytical uncertainty (Table 4). This difference suggests that illitization could have been driven here by a crystalgrowth mechanism (Eberl and rodo ,1988; Hay et al., 1988; Clauer et al., 1997). However, such a crystal growth process has yet only be demonstrated in slow diagenetic illitization and not due to "fast" hydrothermal fluid flows, even at temperatures around $100{ }^{\circ} \mathrm{C}$ (e.g., Clauer et al., 1997; Clauer and Lerman, 2012).

\section{Fluid-rock interactions and impact on the thermal history}

Fluid-inclusion data of quartz overgrowths from Triassic sandstones and of halite crystals from Keuper units above have been published recently (Blaise et al., 2014). Keeping in mind that the micro-thermometric data of fluid inclusions from halite crystals of the Keuper units could have been reset in density during the latest thermal activity, the thermal modeling calibrated against organic matter maturity and apatite fission tracks data indicates that the Callovian-Oxfordian and the Lower Triassic units underwent maximum burial temperatures 
of $50 \pm 5{ }^{\circ} \mathrm{C}$ to $90 \pm 10^{\circ} \mathrm{C}$, which is about $25^{\circ} \mathrm{C}$ higher than the present-day temperature. This temperature offset implies an erosion of several hundred meters of sediments, depending on the thermal flux and conductivity considered. In fact, it is difficult to attribute a precise crystallization temperature to illite because it crystallized after the quartz and feldspar paragenesis, possibly at a slightly higher temperature than that determined for the quartz overgrowths.

A closer look at the diagram displaying a general burial/thermal evolution pattern of the eastern Paris Basin by Blaise et al. (2014) shows significant subsidence accelerations of the Lower-Triassic sandstones from 900 to $1200 \mathrm{~m}$ depth at 190-185 Ma, and from 1400 to 2100 $\mathrm{m}$ depth at 165-145 Ma (Fig. 11). These pronounced subsidence periods were related to structural readjustments of the basement at the scale of the whole basin (Brunet and Le Pichon, 1982; Curnelle and Dubois, 1986). They could therefore have induced and driven migrations of fluids of varied origins and temperatures in the overlaying sediments, as suggested by Clauer et al. (1996) for the south-central basin, on the basis of a similar modeling.

Evidence for supplies of allochtonous fluids was provided by Clauer et al. (1995) who reported varied distinct correlations between $\mathrm{K}-\mathrm{Ar}$ and $\delta^{18} \mathrm{O}$ data for illite-rich separates of Rhaetian sandstones from an identified fault and a nearby unaffected rock of the same southcentral Paris Basin. Illite from fault gouge provided K-Ar ages similar to the oldest ages of illite from undisturbed matrix, between 200 and $185 \mathrm{Ma}$, but with significantly higher $\delta^{18} \mathrm{O}$, from +16 to $+18.5 \%$ ( $\mathrm{V}-\mathrm{SMOW})$, as compared to +13 to $+14 \%$ or for illite from nearby undisturbed matrix. This difference suggests that illite crystallization in the matrix occurred at the same time as in the fault, but at a different temperature and in contact with different fluids. The $\delta^{18} \mathrm{O}$ values obtained here for the nanometric illite fractions were plotted against their KAr ages (Fig. 12). The three fractions of samples EST-1, EST-2 and EST-4 yield almost identical patterns that incline to consider them as representative of an identical crystallization 
process. The K-Ar age decrease within analytical uncertainty from $<0.02 \mu \mathrm{m}$ to $0.02-0.05 \mu \mathrm{m}$ size is accompanied by a concomitant decrease in $\delta^{18} \mathrm{O}$. Although limited and close to the analytical uncertainty, the $\delta^{18} \mathrm{O}$ decrease of 0.1 to $0.3 \%$ o suggests a slight increase of the illite crystallization temperature (Zheng, 1993). However, other factors may have also influenced the $\delta^{18} \mathrm{O}$ such as: (1) a variable water/rock ratio (Uysal and Golding, 2003); (2) a variable chemical composition of the parent fluids (Clauer and Lerman, 2012); or (3) a variable contribution of detrital minerals, especially of quartz, in the coarser fractions. The slightly younger $\mathrm{K}$-Ar age of the $0.02-0.05 \mu \mathrm{m}$ fraction is within the analytical uncertainty, while the lower $\delta^{18} \mathrm{O}$ values for the three EST-4 size fractions located deeper than the EST-1 and EST-2 sandstones are analytically significant, suggesting that they do not result strictly from the same mineral mixtures.

As the finest fractions lack detrital admixtures on the basis of the K-Ar ages, two generations of illite can be inferred depending on the two observed shapes, fibers and platelets, and the chemical compositions. For instance, the 2-\%o decrease of the illite $\delta^{18} \mathrm{O}$ value from samples of the 1825-1882 m interval to those of the 1958-1999 m interval could correspond to distinct fluid/rock interaction during illitization. As already stated, this change could correspond to a temperature increase of about $20{ }^{\circ} \mathrm{C}$ (from 80 to $100{ }^{\circ} \mathrm{C}$ ), regardless of the illite- $\mathrm{H}_{2} \mathrm{O}$ isotopic fractionation curve used (Savin and Lee, 1988; Zheng, 1993; Sheppard and Gilg, 1996). Actually, such a temperature increase cannot be due to a burial-induced process because the samples are distant by less than 200 meters, for which an increase of only $6^{\circ} \mathrm{C}$ can be expected on the basis of a mean geothermal gradient of $30^{\circ} \mathrm{C} / \mathrm{km}$. Alternatively, the $\delta^{18} \mathrm{O}$ difference of $2 \%$ could also result from successive diagenetic episodes, involving fluids with distinct $\delta^{18} \mathrm{O}$ values, which is consistent with the hypothesis of distinct illite shapes crystallizing during independent fluid flows. In this case, the diagenetic assemblage with the lowest $\delta^{18} \mathrm{O}$ values would have crystallized in equilibrium with fluids possibly mixed with low 
$\delta^{18} \mathrm{O}$ meteoric fluids, favoring a relationship with distinct geodynamic events, and not a lasting illitization during continuous burial of the sediments.

\section{Changing chemistry of the interacting fluids}

By combining the $\mathrm{Rb}-\mathrm{Sr}$ data of the untreated fractions and their corresponding leachates, four out of six calculated ages are within analytical uncertainty. This age identity suggests that the ${ }^{87} \mathrm{Sr} /{ }^{86} \mathrm{Sr}$ ratio of the leachates is probably representative for fluids that interacted with the authigenic illite. In fact, the initial ${ }^{87} \mathrm{Sr} /{ }^{86} \mathrm{Sr}$ ratios of the different leachateuntreated couples are quite variable from $0.7108 \pm 0.0001$ to $0.7134 \pm 0.0003$, which inclines one to consider that the soluble components did not result from a unique fluid during a single flow. Also, the rather high values allow discarding a major contribution of pure seawater, whose ${ }^{87} \mathrm{Sr} /{ }^{86} \mathrm{Sr}$ ratios were lower than 0.7076 , during the two episodes of probable illite crystallization (e.g., Jones et al., 1994), while an interaction with meteoric water cannot be excluded. In this case, the fluid ${ }^{87} \mathrm{Sr} /{ }^{86} \mathrm{Sr}$ ratio could have increased due to interactions with altering minerals of the host rocks, as the solute $\mathrm{Sr}$ of the present-day pore fluids of the EST433 drill hole yields an ${ }^{87} \mathrm{Sr} /{ }^{86} \mathrm{Sr}$ ratio of $0.712856 \pm 0.000005$ (Rebeix et al., 2011), which is within the range of the calculated initial ratios of the leachate-untreated couples.

Comparison of the $\mathrm{Rb}-\mathrm{Sr}$ ages of the leachate-untreated fractions with the corresponding $\mathrm{K}-\mathrm{Ar}$ ages shows that the $\mathrm{K}-\mathrm{Ar}$ data points of the two finest $(<0.02$ and 0.02 $0.05 \mu \mathrm{m}$ ) fractions of sample EST-1 belong to the isochron with an age of $179.4 \pm 4.5$, the data point of the coarser fraction $(0.05-0.1 \mu \mathrm{m})$ plotting slightly above the isochron (Fig. 9). In the case of sample EST-2, the K-Ar data points of the two finest fractions plot on the isochron with the younger age of $149.4 \pm 2.5 \mathrm{Ma}$, the data point of the coarsest fraction, again above the isochron, suggesting addition of contaminants of an older authigenic or detrital origin. Only the coarsest fraction of sample EST-1, in which detrital or older high-temperature components are suggested by the low $\delta^{18} \mathrm{O}$ value relative to the finer fractions (Fig. 12), is 
within the individual K-Ar ages. The two finest EST-1 fractions yield $\mathrm{Rb}-\mathrm{Sr}$ ages that are significantly younger than the corresponding K-Ar ages. In the case of sample EST-2, the three fractions yield $\mathrm{Rb}-\mathrm{Sr}$ ages identical to the $\mathrm{K}-\mathrm{Ar}$ isochron age. However, the initial ${ }^{87} \mathrm{Sr} /{ }^{86} \mathrm{Sr}$ ratio of the three size fractions of this EST-2 sample is variable, which is unexpected for mineral (and organic) phases that would have crystallized at the same time from the same fluid of whatever origin and composition.

Theoretically, the K-Ar isochron and Rb-Sr duochron ages of pure authigenic silicates should be identical in the analyzed separates (e.g., Clauer et al., 2003), which is not systematically the case here. A straight explanation is that the initials of the $\mathrm{Rb}-\mathrm{Sr}$ duochrons are not always representative of the ${ }^{87} \mathrm{Sr} /{ }^{86} \mathrm{Sr}$ ratio of the fluids that favored crystallization of illite, because of different $\mathrm{Sr}$ isotopic ratios for the leachates. Variable addition of $\mathrm{Sr}$ with higher ${ }^{87} \mathrm{Sr} /{ }^{86} \mathrm{Sr}$ ratios, for instance by the soluble $\mathrm{Ca}$ and P-rich components basically enriched in $\mathrm{Sr}$, variably modify the slope of the leachate-untreated duochrons and, therefore, change to some extent the Rb-Sr age calculated for the different fractions.

In fact, the ${ }^{87} \mathrm{Sr} /{ }^{86} \mathrm{Sr}$ ratios of the EST-1 duochrons average at $0.7131 \pm 0.0003$, whereas those of the EST-2 duochrons average at $0.7116 \pm 0.0008$. The first of these two mean values corresponds to the initial ${ }^{87} \mathrm{Sr} /{ }^{86} \mathrm{Sr}$ ratio of the finest untreated illite crystals that yield identical $\mathrm{K}-\mathrm{Ar}$ and $\mathrm{Rb}-\mathrm{Sr}$ ages at $180 \pm 5$ and $176 \pm 10 \mathrm{Ma}$, respectively. One may then stipulate that the leachates of sample EST-1 could have been precipitated by the 180-Ma old fluid flow. In the case of sample EST-2, the two finest fractions yield identical Rb-Sr and K-Ar ages at 148 \pm 8 and $150 \pm 3 \mathrm{Ma}$, for a slightly lower initial ${ }^{87} \mathrm{Sr} /{ }^{86} \mathrm{Sr}$ ratio than before, of $0.7116 \pm 0.0008$, which may again reflect the Sr isotopic signature of the soluble phases. In summary, it can be suggested that the ${ }^{87} \mathrm{Sr} /{ }^{86} \mathrm{Sr}$ ratio of the leached soluble components reflects slightly different signatures for the fluids that were active during the 150- and 180-Ma flows. At last but not least, the $\mathrm{Rb}-\mathrm{Sr}$ ages of the coarser fractions of both samples and the intermediate fraction of sample EST-1 are significantly younger at $134 \pm 7$ and $148 \pm 8$ Ma for the $\mathrm{Rb}-\mathrm{Sr}$ data, relative 
to $174 \pm 4,196 \pm 5$ and $168 \pm 4$ Ma for the corresponding individual K-Ar ages. To adjust identical $\mathrm{Rb}-\mathrm{Sr}$ and $\mathrm{K}-\mathrm{Ar}$ ages, it is necessary to conceptually decrease the initial ${ }^{87} \mathrm{Sr} /{ }^{86} \mathrm{Sr}$ ratios of these three fractions, which is a challenging exercise due of numerous uncertainties. A rough calculation provides initial ${ }^{87} \mathrm{Sr} /{ }^{86} \mathrm{Sr}$ ratios between 0.705 and 0.709 , which are within the range of plutonic minerals.

In summary, the $\mathrm{Rb}-\mathrm{Sr}$ data of the nanometric size fractions point to the occurrence of very few and discrete accessory $\mathrm{Mg}$-Ca-carbonates and $\mathrm{Ca}$-phosphates mixed with overwhelming illite separates, explaining why they were only detected by the chemical composition of the leachates. The Rb-Sr data also suggest that the soluble components could have crystallized from migrating fluids during the two fluid-flow episodes at $149.4 \pm 2.5$ and $179.4 \pm 4.5 \mathrm{Ma}$, with slightly different ${ }^{87} \mathrm{Sr} /{ }^{86} \mathrm{Sr}$ signatures. Alternatively, the calculated initial ${ }^{87} \mathrm{Sr} /{ }^{86} \mathrm{Sr}$ signature of the coarser fractions suggests a contamination by silicates of plutonic origin.

\section{$\underline{R E E}$ tracing of the interacting fluids}

Theoretically, REEs can substitute for either $\mathrm{K}$ in the interlayer site, or for Fe, $\mathrm{Mg}$ and Al in the octahedral layer of illite and I-S (Awwiller, 1994). However, they can also occur potentially as minute amounts of accessory detrital monazite and/or apatite in sediments. Only a few studies have reported on REE concentrations of authigenic illite extracted from sandstones (e.g., Zwingmann et al., 1999; Uysal and Golding, 2003; Sant'Anna et al., 2006). Honty et al. (2008) reported the first REE concentrations of nanometric illite-rich materials from Cenozoic argillaceous and bentonite deposits of the East Slovak Basin. These authors found a tendency for REE enrichments with increasing illite particle size (Table 2). If sorption would have acted in the REE distribution here, the REE concentrations should have increased with increasing surface area, i.e., with decreasing size fractions, which is not the case. In spite of variable absolute concentrations, the REE distributions are broadly consistent among the 
different fractions of each sample (Fig. 7), except for the deep EST-6 conglomerate that displays different patterns with a flat contribution for the LREEs and a continuous increase from MREEs to HREEs. The identical REE spectrum among the three fractions of this conglomerate highlights identical mineralogical and chemical compositions. In a similar way, sample EST-4 displays also a remarkable homogeneous REE distribution for the different fractions, despite a slightly older K-Ar age for the coarser fraction. The coarse 0.05-0.1 $\mu \mathrm{m}$ fraction of sample EST-3 yields also a slightly older K-Ar age suggesting the presence of detrital K-bearing detrital or older minerals, whereas the REE patterns are very similar. It looks like the K-Ar system is more sensitive to detrital contamination than the global REE distribution.

In fact, all samples show little variations in the REE concentrations among the different size fractions. The finest fractions $<0.02$ and $0.02-0.05 \mu \mathrm{m}$ of samples EST- 1 and EST-2 show bell-shaped REE patterns with the maximum fractionation ratio for Eu, while the coarser fraction exhibits a slightly flatter distribution pattern. The $\mathrm{Ca}-\mathrm{Mg}$ carbonates in sample EST-1 and mainly of Ca-phosphate in sample EST-2, both mixed with the illite crystals at limited amounts yield similar REE spectra (Fig. 8), however with marked differences in the amounts. These patterns of small amounts of carbonates and phosphates similar to those of the whole fractions do not allow to decide if they interacted with the fluids from which illite crystallized.

The oxidation-reduction state of the fluids is usually assessed by changing $\mathrm{Ce}$ concentrations that result from oxidation of $\mathrm{Ce}^{(\mathrm{III})}$ into its tetravalent state $\mathrm{Ce}^{(\mathrm{IV})}$ (Piper, 1974). Ce is thus either enriched or depleted depending on its oxidation-reduction state (e.g., Landström and Tullborg, 1990). A slightly positive Ce anomaly is visible in all samples here, especially in the intermediate size fractions, except for the deeper EST-6 sample, which displays a negative Ce anomaly. The conglomeratic nature of this sample may have induced higher fluid/rock ratios relative to the above sandstone units, producing more reductive 
conditions, as well as lower $\delta^{18} \mathrm{O}$ values for the finest fractions devoid of detrital contamination. Also noteworthy is the systematic slightly positive Eu anomaly for the nanometric fractions of the other samples, which may have been inherited from dissolved detrital or from authigenic feldspars that crystallized at the same time as illite (e.g., Sant'Anna et al., 2006). This origin appears the most appropriate, as precipitation of minerals with a positive $\mathrm{Eu}$ anomaly from oxygen-poor hydrothermal solutions needs temperatures of more than $200{ }^{\circ} \mathrm{C}$, which was not the case here.

REE contents are generally very low in diagenetic fluids, below the ng/g level (Michard and Albarède, 1986; Michard, 1989; Lewis at al., 1998). At crystal scale, such fluids carry REEs recovered from dissolution of detrital minerals, here mainly K-feldspars and micas that interacted with the nucleating authigenic minerals. Hence, REE patterns of crystallizing illite are expectedly controlled by the REE content of the nearby dissolving detrital feldspar and mica grains from which they inherit most elements transferred into the interactive fluids. Here, K-feldspar was detected by XRD in the 0.02-0.05 and 0.05-0.1 $\mu \mathrm{m}$ fractions of sample EST-5, and in the coarser fraction of sample EST-3 (Table 1). However, no clear contribution of K-feldspar identified by the well-known positive Eu anomaly is observed in the REE distribution of the illite crystals. Therefore, neither authigenic nor detrital K-feldspars appear to have significantly contributed to the REE budget of illite. Conversely and despite the lack of feldspar grains in the untreated fractions, the leachates of the size fractions from EST-1 and EST-2 samples yield significant positive Eu anomalies together with high $\mathrm{Gd}$ or $\mathrm{Tb}$ anomalies, probably because they originated from fluids that precisely did not interact with the silicates. The surprisingly high Gd (and Tm) anomaly(-ies) having not been reported in the mineral world, to the best of our knowledge, they suggest a limited supply of organics by the fluids. This possibility added to the fact that feldspar alteration did obviously not occur during illite crystallization, also discards a potential diagenetic burial-induced process. 
The occurrence of Ca- and P-rich soluble components does not distract from fact that minute amounts of REE-bearing mineral phases, such as apatite, monazite and zircon, even if they have not been detected by XRD could also be present. As these phases are highly enriched in REE relative to illite, even small amounts can influence the global patterns (Awwiller, 1994). Linear correlations between REE and other elements may thus help to identify such REE-bearing accessory minerals (Condie, 1991; Honty et al., 2008). The Caphosphate soluble phase is confirmed by the positive correlation between $\mathrm{P}_{2} \mathrm{O}_{5}$ and $\mathrm{CaO}$ concentrations $(\mathrm{R}=0.87)$ in the leachates of sample EST-2. The fact that it survived the preliminary Jackson (1975) treatment suggests that it was probably intimately mixed with the illite crystals in the rock. Biogenic apatite displays usually bell-shaped REE distribution patterns when normalized to silicate minerals, i.e., it is significantly enriched in MREE (Lécuyer et al., 2004; Reynard et al., 1999). The correlation between $\mathrm{P}_{2} \mathrm{O}_{5}$ and REEs is lacking with respect to the LREEs and HREEs $(\mathrm{R}<0.1)$, but the ratio increases when considering the MREEs $(0.25<\mathrm{R}<0.32)$. Hence, the typical bell-shaped normalized-REE distribution of almost all size fractions may result, at least partly, from occurrence of soluble MREE-enriched biogenic Ca-phosphate, rather than from detrital apatite or monazite, which would also explain the Gd anomaly.

The separates of the conglomeratic EST-6 sample display a different general REE pattern, with a marked enrichment in HREE (Fig. 7). This sample exhibits the highest contents in $\mathrm{Zr}$, ranging from 291 in the coarser fraction to $149 \mu \mathrm{g} / \mathrm{g}$ in the finest. As expected, the Hf contents are well correlated with those of $\mathrm{Zr}(\mathrm{R}=0.99)$. As a common accessory detrital mineral in sandstones, conglomerates and shales, zircon is invariably enriched in HREEs (e.g., Sano et al., 2002). The correlation between $\mathrm{Zr}$ and REE concentrations increases from $\mathrm{R}=0.03$ for the correlation of $\mathrm{Zr}$ vs. $\mathrm{La}$, to $\mathrm{R}=0.92$ for that of $\mathrm{Zr}$ vs. $\mathrm{Lu}$, indicating that zircon undoubtedly contributes, even discretely, to the HREE content in the case of sample EST-6. 
In sum, minute amounts of zircon crystals contaminate nanometric illite fractions, not interfering in the $\mathrm{K}-\mathrm{Ar}$ and $\mathrm{Rb}-\mathrm{Sr}$ ages.

\section{Which driving forces for illitization: progressive burial or episodic fluid flow(s)?}

The debate about the driving force(s) of the described illitization process induced by either progressive burial or episodic hydrothermal fluid-flows in the Triassic sandstones of the Paris Basin was intense during, at least, the recent three decades. An overview of the presentday situation appeared therefore appropriate, because this kind of debate exists for other large sedimentary basins, and because a convincing answer has still to be provided. During progressive burial, K-bearing minerals of sedimentary sequences, such as feldspar, micas, illite, or I-S, undergo alteration of variable extent. This alteration leads to a progressive K-Ar resetting of the detrital silicates next to precipitating authigenic clay crystals (e.g., Hower et al., 1976; Clauer et al., 2014). A major issue is in the fact that such detrital mineral grains, especially the coarser, are frequently only partly altered. Consequently, individual K-Ar ages range generally from crystallization timing of the detrital minerals to that of the mixed authigenic illite and altering detrital minerals. Such geologically meaningless K-Ar ages have been obtained recently by $\mathrm{K}-\mathrm{Ar}$ dating of size fractions coarser than $0.05 \mu \mathrm{m}$ of Triassic sediments of this eastern Paris Basin similar to the coarser fractions studied here (Ploquin, 2011). If illite precipitation is only induced by progressive burial, its intensity increases with increasing depth, the associated illite K-Ar ages decreasing accordingly (Clauer and Lerman, 2012). Such a progressive decrease of the K-Ar signature of burial-induced illitization was well documented in the deeper Gulf Coast sediments (Hower et al., 1976; Awwiller, 1994), and in the Mahakam Delta Basin (Clauer et al., 1999), a complete recrystallization of the detrital grains requiring an appropriate intensity to reset all detritals.

As the $\mathrm{K}-\mathrm{Ar}$ and $\mathrm{Rb}-\mathrm{Sr}$ isotopic ages of the finer separated size fractions from Triassic sandstones of the eastern Paris Basin are younger than the stratigraphic age of the host rocks, 
the crystallization episodes were intense enough to erase the detrital signal in them, unless no detrital grains were small enough to occur in these finest separates. Also, no convincing correlation between individual K-Ar ages and sampling depth could be established (Table 4), probably because of the narrow studied depth interval $(175 \mathrm{~m})$. Therefore, the consistent individual K-Ar ages of the two finer fractions from selected samples confirm that they consist of authigenic illite-rich crystals free of any contamination by K-bearing detrital minerals. This result is of prime importance as it means that any fraction of the Triassic sandstones of the eastern Paris Basin coarser than $0.05 \mu \mathrm{m}$ contains systematically detrital or older K-bearing minerals. In turn, the K-Ar data of such fractions are necessarily meaningless, which is indirectly supported by the oxygen isotope data. In summary, two illite crystallization periods occurred at $179.4 \pm 4.5$ and $149.4 \pm 2.5 \mathrm{Ma}$, on the basis of two K-Ar isochrons secured by an independent statistical calculation. These ages do not correspond to the maximum burial, which occurred significantly later during the Late Cretaceous (Blaise et al., 2014). Therefore, illite precipitation did not relate to progressive burial, but was likely driven by episodic fluid flows during the Early and Late Jurassic, like those advocated by Lampe et al. (2001) in the nearby Rhine Graben. This interpretation is supported by distinct illite crystal morphologies and chemical compositions that might correspond to the two crystallization episodes, as well as by different chemical compositions for the acid leachates of the illite fractions.

Calibration by organic matter maturation and fluid inclusions along the 2000-m long well points to temperatures of about $90 \pm 10{ }^{\circ} \mathrm{C}$ for the Lower-Triassic sandstones (Blaise et al., 2014). Petrographic observations indicating that illite postdates authigenic quartz and Kfeldspars suggest that the quartz-K-feldspar association probably crystallized at a lower temperature than illite, which had to be higher than during early crystallization of kaolinitedickite. These paragenetic, petrographic and chemical data exclude, therefore, any "eodiagenetic" (= early) low-temperature precipitation of K-feldspar together with kaolinite, 
relative to "mesodiagenetic" (= late) quartz cementation together with illite authigenesis, as advocated by El-ghali et al. (2009).

Basically, oxygen isotopes also provide potential information about illite crystallization conditions, especially about temperatures, if the isotopic composition of the parent-fluid is known and the water/rock ratio expectedly high. The water/rock ratio is poorly constrained here, and quartz grains of possible detrital origin might be present in some separates, making speculative the calculation of the illite crystallization temperature based on oxygen isotopes. On the other hand, many studies have shown that temperature is not as critical as previously thought for the nucleation and growth of illite (Brorkum and Gjelsvik, 1988). Recent models for fibrous illite crystallization in sandstones have shown that nucleation and growth are controlled, besides temperature, by the duration of the thermal episode, the activity of $\mathrm{K}^{+}$in the medium, and the salinity of the solution (Lander and Bonnell, 2010). When illitization in sandstones is fueled by punctuated fluid flow events, its crystallization temperatures had to be higher than those reached during the maximum burial of the sediments. Otherwise, radiogenic ${ }^{40} \mathrm{Ar}$ would diffuse out of the crystal lattice with K-Ar ages more or less reset (e.g., Clauer and Chaudhuri, 1995).

\section{$\underline{\text { Review of illitization in Western European Triassic sandstones by Jurassic fluid flows }}$}

A paragenetic sequence similar to that described here was reported in Upper-Triassic sandstones of the central Paris Basin (Demars and Pagel, 1994). The authors hypothesized a high-temperature $\left(100-140^{\circ} \mathrm{C}\right)$ late-Cretaceous episode synchronous with maximum burial. In fact, their unconstrained temperature evaluation is higher than the temperature estimated for maximum burial, suggesting in turn some thermal activity. Spötl et al. (1993) studied Keuper (Upper Triassic) sandstones of the south-central Paris Basin buried at about $2000 \mathrm{~m}$. They distinguished early-diagenetic processes and suggested that $\mathrm{Cl}-\mathrm{Br}$ of the present-day pore waters are representative of fluids saturated with respect to halite that flushed the rock 
sequence during burial. For them, uplift of the eastern border of the basin induced gravitydriven fluid flows towards the west at subsurface temperatures of $\bullet 140{ }^{\circ} \mathrm{C}$. However, they did not relate these high temperatures to advective heat transport, but rather to a combination of maximum burial depth, high surface temperatures and thermal blanketing during Late Cretaceous (100-66 Ma). And last not least, Gonçalvès et al. (2010) published an evolutionary model based on fluid-inclusion constraints of Dogger and Keuper formations, favoring, again, a burial-induced evolution apparently simulated for the quartz and K-feldspar crystallization episodes.

On the other hand, Buntsandstein (Lower Triassic) sandstones of the Saverne fracture field in the Vosges Massif, or buried deeply in the Rhine Graben (3000 m) at a present-day temperature of about $160{ }^{\circ} \mathrm{C}$ (Clauer et al., 2008), contain illite typologies similar to those observed here in the EST433 well. These occurrences have been explained by a faulting tectonic activity in the crystalline basement visible in the field around Saverne that induced fluid migrations into the porous sandstones either covering the crystalline massif, or deposited in the nearby basin to the East of the Vosges mountains, with subsequent illitization. Rhaetien (Uppermost Triassic) sandstone cores from southern Paris Basin collected at depths between 1000 and $2700 \mathrm{~m}$ contain similar illite typologies mixed with kaolinite and some chlorite (Clauer et al., 1995). In the Saverne fracture field and in the close eastern basin that is now the Rhine Graben, illite crystallized at 185-210 and 155-175 Ma (Clauer et al., 2008) and at about 190 and $150 \mathrm{Ma}$ in the Rhaetian (Upper Triassic) sandstones from south-central Paris Basin (Mossmann et al., 1992). On the basis of $\delta^{18} \mathrm{O}$ values of the authigenic illite and the associated authigenic quartz, a crystallization temperature of $220-250{ }^{\circ} \mathrm{C}$ was advocated at $\sim 190 \mathrm{Ma}$ for the hydrothermal fluid flow in this southern Paris Basin (Clauer et al., 1995). This crystallization temperature was probably overestimated as it was obtained by assuming a contemporaneous crystallization of illite and quartz, which could have not been the case. However, the hydrothermal activity had also to exist in the central basin as some of the 
studied rocks display fault/fracture structures. Two younger I-S generations were identified in these horizons and $\mathrm{K}$-Ar dated at $\sim 150$ and $\sim 80 \mathrm{Ma}$ at progressively decreasing temperatures (Clauer et al., 1995). Spötl et al. (1996) refuted this interpretation, favoring again a burialdriven authigenic illitization of these Upper-Triassic sediments.

The K-Ar ages of authigenic illite in the Triassic sandstones from eastern Paris Basin document two crystallization episodes during the Early-Middle Jurassic (PliensbachianAalenian) and Late Jurassic (Oxfordian-Tithonian). This Jurassic period is known to have seen a regional extensional tectonic regime (E-W to NW-SE) correlated with an increase of the sediment accommodation rate (Guillocheau et al., 2000; Ferry et al., 2007). It was linked to thermal doming in the North Sea and opening of the central Atlantic rift (Curnelle and Dubois, 1986). Similarly, substantial increase in the subsidence rate was identified in the Paris Basin during Early and Late Jurassic (Guillocheau et al., 2000; Ferry et al., 2007). This thermal anomaly linked to the North-Atlantic rifting that induced large-scale fluid flows. During the Jurassic-Cretaceous transition, the eastern border of the basin started to rise (Guillocheau et al., 2000; Brigaud et al., 2009). Hydrothermal activity has been reported independently along the southern margin of the basin (e.g., U deposits in the southern Central Massif, Lancelot and Vella, 1989; Respaut et al., 1991; F-Ba mineralizations in the Morvan area, Joseph et al., 1973), as well as in the southern Vosges Massif (Edel, 1997). In fact, widespread Early-Jurassic ages were evidenced by K-Ar dating of authigenic illite in Permian and Triassic sandstones at the whole West-European scale (Clauer et al., 1996b), as well as in correlative U and F-Ba-Pb-Zn deposits (Brockamp and Clauer, 2005; Cathelineau et al., 2012).

In summary, Early Jurassic ( $180 \mathrm{Ma})$ and Late Jurassic-Early Cretaceous ( $150 \mathrm{Ma})$ rifting events were recorded in the Paris Basin and its margins (Fig. 13), as well as in many locations of Western Europe by the impact of the concomitantly driven fluid flows. At a global scale, intense volcanic activity occurred also during these periods with a significant 
increase of the seawater temperature (Dera et al., 2011). Thermal anomalies and heat transfers related to successive stages of the North Atlantic opening induced: (1) major increases of the subsidence motion in the Paris Basin due to basement readjustments, (2) large-scale fluid flows at the origin of illite crystallization in Permian and Triassic sandstones (Clauer et al., 1996b; this study), and (3) U, F-Ba-Pb-Zn concentrations at the southwestern margin of the Paris Basin (Cathelineau et al., 2012), and non-mineralizing tectonically driven hydrothermal activity at the southeastern margin of the French Central Massif (Brockamp and Clauer, 2013).

In fact, the area investigated here was rather devoid of major tectonic activity, the uppermost Oxfordian and Kimmeridgian sequences being the only ones affected by Cenozoic tectonic episodes related to Pyrenean and Alpine orogeny episodes (André et al., 2010). In the Bathonian and Bajocian limestones buried at $~ 500$ to $800 \mathrm{~m}$, calcite crystallization was dated by the U-Pb method at $149.2 \pm 5.8 \mathrm{Ma}$ (Pisapia et al., 2011), which is strikingly consistent with the youngest illitization episode in the Lower-Triassic sandstones. Being vertically separated from each other by more than $1000 \mathrm{~m}$ of very low permeable sediments (Triassic and Lower-Jurassic claystones and marls, and non-permeable Upper-Triassic halite layers), fluid transfers from the lowermost siliciclastic Triassic aquifer to the uppermost limestone Bajocian-Bathonian aquifer appear very unlikely. Called "cross-formational flows" by Worden and Matray (1995), such transfers were, however, mentioned by Demars (1994) for interpreting saline paleo-fluids with a Triassic signature in authigenic calcite cements of Dogger formations of the central Paris Basin. To date, no determining indices are available to invoke this process for the eastern basin.

The eastern section of the Paris Basin was located several hundred kilometers away from the North Atlantic rift zone during the whole Jurassic time, while closer to the eastern plutonic basement of the not yet emerged Vosges Massif. Noteworthy in this respect, is the fact that grabens, such as that of Gondrecourt close to the study site, were shaped during more 
recent extensional tectonic activities in relation with the rifting of the Rhine Graben (André et al., 2010). The fact that major cementation episodes in such a quiescent area are linked to distant geodynamical activity, suggests that wide wavelength thermal anomalies may relate to large-scale fluid flows (Cathelineau et al., 2012). Such anomalies may induce porosity/permeability losses in reservoir rocks during mineralization episodes at the margin of sedimentary basins. The fact that Jurassic tectonic activities were recorded in the remote eastern border of the Paris Basin highlights the complex relationship between geodynamical events, thermal anomalies and correlated fluid movements.

\section{Conclusions}

Despite only buried to $2500 \mathrm{~m}$ in the past, and despite the absence of apparent major tectonic activity, the Early- to Middle-Triassic sandstones of the eastern Paris Basin underwent extensive illite precipitation. The finest $<0.02$ and $0.02-0.05 \mu \mathrm{m}$ illite separates of such sandstones yield K-Ar ages at $179.4 \pm 4.5$ and $149.4 \pm 2.5 \mathrm{Ma}$ on the basis of two isochron plots. The coarser $0.05-0.1 \mu \mathrm{m}$ fractions yield older $\mathrm{K}-\mathrm{Ar}$ ages, lower $\delta^{18} \mathrm{O}$ values and changing REE distributions for five out of the six analyzed samples, indicating admixture of earlier crystallized or distinct detrital minerals of plutonic origin displaying an incomplete isotopic resetting, and therefore meaningless isotopic ages.

The finest $<0.02 \mu \mathrm{m}$ fractions yield slightly older ages than the $0.02-0.05 \mu \mathrm{m}$ fraction, however within analytical uncertainty, suggesting that illitization proceeded during two fluidflow events, with nucleation of illite plates or laths and soluble mineral phases yielding variable chemical compositions. The $\delta^{18} \mathrm{O}$ values are not consistent with a burial-driven illitization, rather supporting the two-stage event set by $\mathrm{K}$-Ar dating, as do the $\mathrm{Rb}-\mathrm{Sr}$ data. The chemical data of the leachates suggest discrete occurrences of accessory Mg-Cacarbonate and Ca-phosphate phases mixed with the illite crystals. The two fluid-flow events 
fit with identified episodes of successive rifting stages of the central Atlantic Ocean where increasing heat flows and associated fluid circulations induced several mineralization (F-Ba$\mathrm{Pb}-\mathrm{Zn}, \mathrm{U}$ ) episodes along the margin of the basin and the Central Massif, as well as extensive illitization in Triassic and Permian sandstones in many locations of Western Europe.

From a methodological point of view, this study demonstrates that separation of nanometric-sized illite particles is essential for determining diagenetic conditions involving interactions with fluids in shallowly buried sandstone-type sediments. Also, size fractions, even as fine as $0.05-0.1 \mu \mathrm{m}$, appear polluted by detrital components, therefore providing biased information on low-temperature diagenetic fluid-mineral interactions.

\section{Acknowledgements}

We are indebted to A.E. Fallick and two anonymous reviewers for their very constructive comments and remarks that helped improving this draft. The discussions about the meaning of the K-Ar ages were intense with C. Hall, the Associate Editor. Our sincere thanks go also to the Scientific Direction of Andra, especially P. Landrein, for having made the drill cores available to us as well as all the related scientific information, for funding Thomas Blaise's $\mathrm{PhD}$, and given us the opportunity to publish the results. We are also thankful to the GNR FORPRO for contribution to the funding of this study in the program TAPSS 2000 (action FORPRO 2009-IV). Special thanks are for Mrs M. Zielinska of the Geological Institut of Krakow for her excellent technical contribution in the size-fractionation procedure. At last and not least, support from Labex ANR-10-LABX-21-01 Ressources21 (Strategic metal resources of the 21 st century) project that initiates a renewed consideration of $\mathrm{K}$-Ar application to small-sized minerals, and the in-progress building of a K-Ar laboratory at Georessources Nancy is also gratefully acknowledged. 


\section{References}

André, G., Hibsch, C., Fourcade, S., Cathelineau, M., and Buschaert, S., 2010. Chronology of fracture sealing under a meteoric fluid environment: Microtectonic and isotopic evidence of major Cainozoic events in the eastern Paris Basin (France). Tectonophysics 490, 214228.

Awwiller, D.N., 1994. Geochronology and mass transfer in Gulf Coast mudrocks (southcentral Texas, U.S.A.): Rb-Sr, Sm-Nd and REE systematic. Chemical Geology 116, 6184.

Bjørlykke, K., and Egeberg, P.K., 1993. Quartz cementation in sedimentary basins. American Association of Petroleum Geologists Bulletin 77, 1538-1548.

Blaise, T., 2012. Histoire thermique et interactions fluides-roches dans l'Est du Bassin de Paris. PhD Thesis, University of Lorraine, Nancy,

Blaise, T., Izart, A., Michels, R., Suarez-Ruiz, I., Cathelineau, M., and Landrein, P., 2011. Vertical and lateral changes in organic matter from the Mesozoic, eastern Paris Basin: Variability of sources and burial history. International Journal of Coal Geology 88, 163 178.

Blaise, T., Barbarand, J., Kars, M., Ploquin, F., Aubourg, C., Brigaud, B., Cathelineau, M., El Albani, A., Gautheron, C., Izart, A., Janots, D., Michels, R., Pagel, M., Pozzi, J.P., Boiron, M.C., and Landrein, P., 2013. Reconstruction of low temperature $\left(<100{ }^{\circ} \mathrm{C}\right)$ in sedimentary basins: A comparison of geothermometers in the intracontinental Paris Basin. Marine and Petroleum Geology 20, 1-17.

Bonhomme, M., Thuizat, R., Pinault, T., Clauer, N., Wendling, R., and Winkler, R., 1975. Méthode de datation potassium-argon. Appareillage et technique: Technical report of the Centre de Géochimie de la Surface, Université Louis Pasteur Strasbourg, 53p. 
Bourquin, S., Peron, S., and Durand, M., 2006. Lower Triassic sequence stratigraphy of the western part of the Germanic Basin (west of Black Forest): Fluvial system evolution through time and space. Sedimentary Geology 186, 187-211.

Bowers, T.S., Jackson, K.J., and Helgeson, H.C., 1984. Equilibrium activity diagrams for coexisting minerals and aqueous solutions at pressures and temperatures to $5 \mathrm{~Kb}$ and $600^{\circ} \mathrm{C}$. Springer Verlag, New-York, 397p.

Brigaud, B., Durlet, C., Deconinck, J.F., Vincent, B., Thierry, J., and Trouiller, A., 2009. The origin and timing of multiphase cementation in carbonates: Impact of regional scale geodynamic events on the Middle Jurassic Limestones diagenesis (Paris Basin, France). Sedimentary Geology 222, 161-180.

Brockamp, O., and Clauer, N., 2005. A km-scale illite alteration zone in sedimentary wall rocks adjacent to a hydrothermal fluorite vein deposit. Clay Minerals 40, 245-260.

Brockamp, O., Schlegel, A., and Clauer, N., 2011. Mesozoic hydrothermal impact on Rotliegende and Bunter immature sandstones of the High Rhine trough and its adjacent eastern area (southern Black Forest, Germany). Sedimentary Geology 234, 76-88.

Brockamp, O., and Clauer, N., 2013. Hydrothermal and unexpected diagenetic alteration in Permian shales of the Lodève epigenetic U-deposit of southern France, traced by K-Ar illite and K-feldspar dating. Chemical Geology 357, 18-28.

Brooks, C., Hart, S., and Wendt, T., 1972. Realistic use of two-error regression treatments as applied to rubidium-strontium data. Reviews in Geophysical Space Physics 10, 551-577.

Brorkum, P.A., and Gjelsvik, N., 1988. An isochemical model for formation of authigenic kaolinite, K-feldspar and illite in sediments. Journal of Sedimentary Petrology 58, 506511.

Brunet, M.F., 1980. Effet des variations eustatiques sur la subsidence dans le Bassin de Paris. Bulletin de la Société géologique de France 7, 631-637. 
Brunet, M.F., and Le Pichon, X., 1982. Subsidence of the Paris Basin. Journal of Geophysical Research 87, 8547-8560.

Burley, S.D., and Worden, R., 2003. Sandstone diagenesis: recent and ancient. Reprint series volume 4 of the International Association of Sedimentologists, John Wiley \& Sons, 656p.

Caillière, S., Hénin, S., and Rautureau, M., 1982. Minéralogie des argiles. Masson, 373p.

Cathelineau, M., Fourcade, S., Clauer, N., Buschaert, S., Rousset, D., Boiron, M.C., Meunier, A., Lavastre, V., and Javoy, M., 2004. Dating multistage paleofluid percolations: A K-Ar and ${ }^{18} \mathrm{O} / /^{16} \mathrm{O}$ study of fracture illites from altered Hercynian plutonites at the basement/cover interface (Poitou High, France). Geochimica et Cosmochimica Acta 68, 2529-2542.

Cathelineau, M., and Boiron, M.C., 2010. Downward penetration and mixing of sedimentary brines and dilute hot waters at $5 \mathrm{~km}$ depth in the granite basement at Soultz-sous-Forêts (Rhine graben, France). Comptes Rendus Geoscience 342, 560-565.

Cathelineau, M., Boiron, M.C., Fourcade, S., Ruffet, G., Clauer, N., Belcourt, O., Coulibaly, Y., Banks, D.A., and Guillocheau, F., 2012. A major Late Jurassic fluid event at the basin/basement unconformity in western France: ${ }^{40} \mathrm{Ar} /{ }^{39} \mathrm{Ar}$ and $\mathrm{K}-\mathrm{Ar}$ dating, fluid chemistry, and related geodynamic context. Chemical Geology 322-323, 99-120.

Clauer, N., 1982. Strontium isotopes of Tertiary phillipsites from the Southern Pacific: timing of the geochemical evolution. Journal of Sedimentary Petrology 52, 1003-1009.

Clauer, N., 2011. Another insight into the illitization process by K-Ar dating of micro- to nano-metric illite-type particles leached with alkylammonium cations. Clay Minerals 46, 593-612.

Clauer, N., Chaudhuri, S., Kralik, M., and Bonnot-Courtois C., 1993. Effects of experimental leaching on $\mathrm{Rb}-\mathrm{Sr}$ and $\mathrm{K}-\mathrm{Ar}$ isotopic systems and REE contents of diagenetic illite. Chemical Geology 103, 1-16. 
Clauer, N., and Chaudhuri, S., 1995. Clays and in crustal environments, isotope dating and tracing. Springer-Verlag, Heidelberg, 359 p.

Clauer, N., O’Neil, J.R., and Furlan, S., 1995. Clay minerals as records of temperature conditions and duration of thermal anomalies in the Paris Basin, France. Clay Minerals $30,1-13$.

Clauer, N., O’Neil, J.R., Furlan, S., and Mossmann, J.R., 1996a. Clay minerals as records of temperature conditions and duration of thermal anomalies in the Paris Basin, France: A reply to the discussion by Spötl et al. Clay Minerals 31, 209-215.

Clauer, N., Zwingmann, H., and Chaudhuri, S., 1996b. Isotopic (K-Ar and oxygen) constraints on the extent and importance of the Liassic hydrothermal activity in Western Europe. Clay Minerals 31, 301-318.

Clauer, N., Srodon, J., Francu, J., and Sucha, V., 1997. K-Ar dating of illite fundamental particles separated from illite-smectite. Clay Minerals 32, 181-196.

Clauer, N., Rinckenbach, T., Weber, F., Sommer, F., Chaudhuri, S., and O'Neil, J.R., 1999. Diagenetic evolution of clay minerals in oil-bearing Neogene sandstones and associated shales from Mahakam Delta Basin (Kalimantan, Indonesia). American Association of Petroleum Geologists Bulletin 83, 62-87.

Clauer, N., Liewig, N., Pierret, M.C., and Toulkeridis, T., 2003. Crystallization conditions of fundamental particles from mixed-layers illite-smectite of bentonites based on isotopic data (K-Ar, Rb-Sr and $\left.\delta^{18} \mathrm{O}\right)$. Clays and Clay Minerals 51, 664-674.

Clauer, N., Liewig, N., Ledesert, B., and Zwingmann, H., 2008. Thermal history of Triassic sandstones from the Vosges mountains-Rhine Graben rifting area, NE-France, based on K-Ar illite dating. Clay Minerals 43, 363-379.

Clauer, N., O’Neil, J.R., Honnorez, J., and Buatier, M., 2011. ${ }^{87} \mathrm{Sr} /{ }^{86} \mathrm{Sr}$ and ${ }^{18} \mathrm{O} /{ }^{16} \mathrm{O}$ ratios of clay minerals from a hydrothermal mound near the Galapagos rift as records of origin, crystallization temperature and fluid composition. Marine Geology 288, 32-42. 
Clauer, N., and Lerman, A., 2012. Thermal history analysis of sedimentary basins : An isotopic approach to illitization. In: Harris N.D. and Peters K. (eds), Thermal History Analysis of Sedimentary Basins: Methods and Case Histories. Society of Economic Paleontologists and Mineralogists, Special Publication 11, 125-146.

Clauer, N., Lewan, M.D., Dolan, M.P., Chaudhuri, S., and Curtis, J.B., 2014. Mineralogical, chemical and K-Ar isotopic changes in Kreyenhagen Shale whole rocks and $<2 \mu \mathrm{m}$ fractions during natural burial and hydrous-pyrolysis experimental maturation. Geochimica et Cosmochimica Acta 130, 93-112.

Clayton, R.N., and Mayeda, T.K., 1963. The use of bromine pentafluoride in the extraction of oxygen from oxides and silicates for isotopic analysis, Geochimica et Cosmochimica Acta 27, 43-52.

Condie, K.T., 1991. Another look at rare earth elements in shales. Geochimica et Cosmochimica Acta 55, 2527-2531.

Curnelle, R., and Dubois, P., 1986. Evolution mésozoïque des grands bassins sédimentaires français ; bassin de Paris, d'Aquitaine et du Sud-Est. Bulletin de la Société géologique de France 8, 529-546.

Dalrymple, G.B., and Lanphere, M.A., 1969. Potassium-Argon Dating. Principles, Techniques and Applications to Geochronology. Freeman W.H. and Company, San Francisco, 258p.

Demars, C., 1994. Évolution diagénétique, paléofluides et paléothermicité dans les réservoirs du Keuper et du Dogger du bassin de Paris, PhD thesis, Institut National Polytechnique de Lorraine, Nancy, France.

Demars, C., and Pagel, M., 1994. Paléotempératures et paléosalinités dans les grès du Keuper du Bassin de Paris : inclusions fluides dans les minéraux authigènes, Comptes Rendus à l'Académie des Sciences, Paris, Série II, 427-434. 
Dera, G., Brigaud, B., Monna, F., Laffont, R., Pucéat, E., Deconinck, J.-F., Pellenard, P., Joachimski, M.M., and Durlet, C., 2011. Climatic ups and downs in a disturbed Jurassic world. Geology 39, 215-218.

Eberl, D.D., and rodo , J., 1988. Ostwald ripening and interparticle-diffraction effects for illite crystals. American Mineralogist 73, 1335-1345.

Edel, J.B., 1997. Les réaimantations post-permiennes dans le bassin dévono-dinantien des Vosges méridionales : existence d'une phase de réaimantation au Lias, contemporaine de minéralisations d'ampleur régionale. Comptes-Rendus de l'Académie des Sciences de Paris 324, Série II, 617-624.

El-ghali, M.A.K., Morad, S., Mansurbeg, H., Caja, M.A., Sirat, M., and Ogle, N., 2009. Diagenetic alterations related to marine transgression and regression in fluvial and shallow marine sandstones of the Triassic Buntsandstein and Keuper sequence, The Paris Basin, France. Marine and Petroleum Geology 26, 289-309.

Ferry, S., Pellenard, P., Collin, P.Y., Thierry, J., Marchand, D., Deconinck, J.-F., Robin, C., Carpentier, C., Durlet, C., and Curial, A., 2007. Synthesis of recent stratigraphic data on Bathonian to Oxfordian deposits of the eastern Paris Basin. Mémoire de la Société géologique de France 178, 37-57.

Govindaraju, K., 1994. Compilation of working values and sample description for 383 geostandards. Geostandards Newsletter 18 (Special Issue) 1-158.

Gonçalvès, J., Pagel, M., Violette, S., Guillocheau, F., and Robin, C. 2010. Fluid inclusions as constraints in a three-dimensional hydro-thermo-mechanical model of the Paris basin, France. Basin Research 22, 699-716.

Guillocheau, F., Robin, C., Allemand, P., Bourquin, S., Brault, N., Dromart, G., Friedenberg, R., Garcia, J.-P., Gaulier, J.-M., Gaumet, F., Grosdoy, B., Hanot, F., Le Strat, P., Mettraux, M., Nalpas, T., Prijac, C., Rigollet, C., Serrano, O., and Grandjean, G., 2000. 
Meso-Cenozoic geodynamic evolution of the Paris Basin: 3D stratigraphic constraints. Geodynamica Acta 13, 189-245.

Hay, R.L., Lee, M., Kolata, D., Matthews, J.C., and Morton, J.P., 1988. Episodic potassic diagenesis of Ordovician tuffs in the Mississippi Valley area. Geology 16, 743-747.

Honty, M., Clauer, N., and Šucha, V., 2008. Rare-earth elemental systematic of mixedlayered illite-smectite from sedimentary and hydrothermal environments of the Western Carpathians (Slovakia). Chemical Geology 249, 167-190.

Hower, J., Eslinger, E.V., Hower, M.E., and Perry, E.A., 1976. Mechanism of burial metamorphism of argillaceous sediments, 1. Mineralogical and chemical evidence. Geological Society of America Bulletin 87, 725-737.

Inoue, A., Kohyama, N., Kitagawa, R., and Watanabe, T., 1987. Chemical and morphological evidence for the conversion of smectite to illite. Clays and Clay Minerals 35, 111-120.

Jackson, M.L., 1975, Soil Chemical Analysis - Advanced Course. Madison, Wisconsin, 386p. Jones, C.E., Jenkins, H.C., Coe, A.L., and Hesselbo, S.P., 1994. Strontium isotopic variations in Jurassic and Cretaceous seawater. Geochimica et Cosmochimica Acta 58, 3061-3074.

Joseph, D., Leghu, J., and Touray, J.C., 1973. Un témoin d'une activité géothermique au Lias dans le Morvan: le filon René-Bis (La Petite-Verrière, Saône-et-Loire). Bulletin du Bureau de Recherche Géologique et Minière 2, 389-401.

Ketcham, R.A., Donelick, R.A., Donelick, M.B., 2000. AFTSolve: a program for multikinetic modeling of apatite fission-track data. Geological Materials Research 2, 1-32.

Komninou, A., and Yardley, B.W.D., 1997. Fluid-rock interactions in the Rhine Graben: A thermodynamic model of the hydrothermal alteration observed in deep drilling. Geochimica et Cosmochimica Acta 61, 515-531.

Kostov, I., 1968. Mineralogy, Oliver and Boyd, Edinburgh and London, 587p. 
Lampe, C., Person, M., Nöth, S., and Ricken, W., 2001. Episodic fluid flow within continental rift basins: Some insights from field data and mathematical models of the Rhinegraben. Geofluids 1, 42-52.

Lancelot, J., and Vella, V., 1989. Datation U-Pb liasique de la pechblende de Rabejac. Mise en évidence d'une préconcentration uranifère permienne dans le bassin de Lodève (Hérault). Bulletin de la Société géologique de France 8, 309-315.

Lander, R.H., and Bonnell, L.M., 2010. A model for fibrous illite nucleation and growth in sandstones. American Association of Petroleum Geologists Bulletin 94, 1161-1187.

Landrein, P., Vigneron, G., Delay, J., Lebon, P., and Pagel, M., 2013. Lithologie, hydrodynamisme et thermicité dans le système sédimentaire multicouche recoupé par les forages Andra de Montiers-sur-Saulx (Meuse). Bulletin de la Société géologique de France, 184, 519-543.

Landström, O., and Tullborg, E., 1990. The influence of fracture mineral/groundwater interaction on the mobility of $\mathrm{U}$, Th, REE and other trace elements. SKB Technical Report, TR 90-37, SKB, Stockholm, Sweden.

Lanson, B., Beaufort, D., Berger, G., Baradat, J., and Lacharpagne, J.C., 1996. Illitization of diagenetic kaolinite-to-dickite conversion series: late-stage diagenesis of the lower Permian Rotligend sandstone reservoir, offshore of the Netherlands. Journal of Sedimentary Petrology 66, 501-518.

Lanson, B., Beaufort, D., Berger, G., Bauer, A., Cassagnabère, A., and Meunier, A., 2002. Authigenic kaolin and illitic minerals during burial diagenesis of sandstones : a review. Clay Minerals 37, 1-22.

Lécuyer, C., Reynard, B., and Grandjean, P., 2004. Rare earth element evolution in Phanerozoic seawater recorded in biogenic apatite. Chemical Geology 204, 63-102. 
Lee, J.Y., Marti, K., Severinghaus, J.P., Kawamura, K., Yoo, H.S., Lee, J.B., and Kim, J.S., 2006. A redetermination of the isotopic abundances of atmospheric Ar. Geochimica et Cosmochimica Acta 70, 4507-4512.

Le Roux, J., 1980. La tectonique de l'auréole orientale du Bassin de Paris. Ses relations avec la sédimentation. Bulletin de la Société géologique de France 4, 655-662.

Lewis, A.J., Koninou, A., Yardley, B.W.D., and Palmer, M.R., 1998. Rare earth element speciation in geothermal fluids from Yellowstone National Park, Wyoming, USA. Geochimica et Cosmochimica Acta 62, 657-663.

Liewig, N., Clauer, N., and Sommer, F., 1987. Rb-Sr and K-Ar dating of clay diagenesis in Jurassic sandstone reservoirs, North Sea. American Association of Petroleum Geologists Bulletin 71, 1467-1474.

Ludwig, K., 2001. Isoplot/Ex, rev. 2.49: a geochronological toolkit for Microsoft Excel. Berkeley Geochronology Center.

Macchi, L., 1987. A review of sandstone illite cements and aspects of their significance to hydrocarbon exploration and development. Journal of Geology 22, 333-345.

Mégnien, C., 1980. Tectogenèse du Bassin de Paris: Etapes de l'évolution du bassin. Bulletin de la Société géologique de France 4, 669-680.

Michard, A., and Albarède, F., 1986. The REE content of some hydrothermal fluids. Chemical Geology 55, 51-60.

Michard, A., 1989. Rare earth element systematic in hydrothermal fluids. Geochimica et Cosmochimica Acta 53, 745-750.

Mossman, J.R., Clauer, N., and Liewig, N., 1992. Dating thermal anomalies in sedimentary basins: the diagenesis history of clay minerals in the Triassic sandstones of the Paris Basin, France. Clay Minerals 27, 211-226.

Nadeau, P.H., Wilson, M.J., McHardy, W.J., and Tait, J.M., 1984. Interstratified clays as fundamental particles. Science 225, 923-925. 
Odin, G.S., and 35 collaborators, 1982. Interlaboratory standards for dating purposes, in Odin, G. S. (Ed.), Numerical Dating in Stratigraphy, Part 1, John Wiley and Sons, Chichester, $123-148$.

Patrier, P., Beaufort, D., Bril, H., Bonhomme, M., Fouillac, A.M., and Aumaitre, R., 1997. Alteration-mineralization at the Bernardan U deposit (Western Marche, France); the contribution of alteration petrology and crystal chemistry of secondary phases to a new genetic model. Economic Geology 92, 448-467.

Perrodon, A., and Zabek, J., 1991. Paris Basin, (interior intracratonic basins). American Association of Petroleum Geologists Memoirs 633-679.

Pin, C., Joannon, S., Bosq, C., Le Fèvre, B., and Gauthier, P.J., 2003. Precise determination of $\mathrm{Rb}, \mathrm{Sr}, \mathrm{Ba}$ and $\mathrm{Pb}$ in geological materials by isotope dilution and ICP-quadrupole mass spectrometry following selective separation of the analytes. Journal of Analytical Spectrometry 18, 135-141.

Piper, D.Z., 1974. Rare earth elements in the sedimentary cycle: a summary. Chemical Geology 14, 285-304.

Piper, D.Z., and Bau, M., 2013. Normalized rare earth elements in water, sediments, and wine: Identifying sources and environmental redox conditions. American Journal of Analytical Chemistry 4, 69-83.

Pisapia, C., Deschamps, P., Hamelin, B., Battani, A., Buschaert, S., and David, J., 2011. U/Pb dating of geodic calcites: A tool for paleohydrological reconstructions. Goldschmidt, Prague 2011, International Meeting.

Ploquin, F., 2011. Argiles, traceurs de paléoconditions diagénétiques et hydrothermales. Recherche des évidences minéralogiques et géochimiques de l'hydrothermalisme dans les formations diagénétiques argileuses, gréseuses et carbonatées du Trias du Bassin parisien. PhD thesis, University of Poitiers, France. 
Quesnel, F., 2003. Paleoweathering and paleosurfaces from northern and eastern France to Belgium and Luxembourg. Géologie de la France 1, 95-104.

Rebeix, R., Le Gal La Salle, C., Michelot, J.L., Verdoux, P., Noret, A., Monvoisin, G., Gianesinni, S., Lancelot, J., Simler, R., 2011. Tracing the origin of water and solute transfers in deep groundwater from Oxfordian, Dogger and Trias formations in the east of the Paris Basin - France. Physics and Chemistry of the Earth 36, 1496-1510.

Respaut, J.P., Cathelineau, M., and Lancelot, J.R., 1991. Multistage evolution of the Pierres Plantées uranium ore deposit (Margeride, France): Evidence from mineralogy and U-Pb systematic. European Journal of Mineralogy 3, 85-103.

Reynard, B., Lécuyer, C., and Grandjean, P., 1999. Crystal-chemical controls on rare-earth element concentrations in fossil biogenic apatites and implications for paleoenvironmental reconstructions. Chemical Geology 155, 233-241.

Roddick J.C., 1987. Generalized numerical error analysis with applications to geochronology and thermodynamics. Geochimica et Cosmochimica Acta 51, 2129-2135.

Samuel, J., Rouault, R., and Besnus, Y., 1985. Analyse multi-élémentaire standardisée des matériaux géologiques en spectrométrie d'émission par plasma à couplage inductif. Analusis 13, 312-317.

Sano, Y., Terada, K., and Fukuoka, T., 2002. High mass resolution ion microprobe analysis of rare earth elements in silicate glass, apatite and zircon: lack of matrix dependency. Chemical Geology 184, 217-230.

Sant'Anna, L.G., Clauer, N., Cordani, U.G., Riccomini, C., Velazquez, V.F., and Liewig, N., 2006. Origin and migration timing of hydrothermal fluids in sedimentary rocks of the Parana Basin, South America. Chemical Geology 230, 1-21.

Savin, S.M., and Lee, M., 1988. Isotopic studies of phyllosilicates. In: Bailey S.W. (Ed.), Hydrous phyllosilicates. Reviews in Mineralogy 19, 189-223. 
Schlegel, A., Brockamp, O., and Clauer, N., 2007. Response of clastic sediments to episodic hydrothermal fluid flows in intramontane troughs: a case study from Black Forest, Germany. European Journal of Mineralogy 19, 833-848.

Semhi, K., Clauer, N., and Chaudhuri, S. 2014. Changing elemental uptake of radish seedlings grown in $\mathrm{Cd}$ and $\mathrm{Pb}$ polluted smectite substrates. Applied Clay Science 99, 171177.

Sheppard, S.M.F., and Gilg, H.A., 1996. Stable isotope geochemistry of clay minerals, Clay Minerals 31, 1-24.

Sircombe, K.N., 2004. AGEDISPLAY: an EXCEL workbook to evaluate and display univariate geochronological data using binned frequency histograms and probability density distributions. Computer Geosciences 30, 21-31.

Small, J.S., Hamilton, D.L., and Habesch, S., 1992. Experimental simulation of clay precipitation within reservoir sandstones 2 : mechanism of illite formation and controls on morphology. Journal of Sedimentary Petrology 62, 520-529.

Smith, M.P., Savary, V., Yardley, B.W.D., Valley, J.W., Royer, J.J., and Dubois, M., 1998. The evolution of the deep flow regime at Soultz-sous-Forêts, Rhine Graben, eastern France: Evidence from a composite quartz vein. Journal of Geophysical Research 103 (B11), 27223-27237.

Spötl, C., Matter, A., and Brévart O., 1993. Diagenesis and pore water evolution in the Keuper reservoir, Paris Basin (France). Journal of Sedimentary Petrology 63, 909-928.

Spötl, C., Worden, R.H., and Walgenwitz, F., 1996. Clay Minerals as records of temperature conditions and duration of thermal anomalies in the Paris Basin, France: Discussion. Clay Minerals 31, 203-208.

rodo, J., Elsass, F., McHardy, W.J., and Morgan, D.J., 1992. Chemistry of illite/smectite inferred from TEM measurements of fundamental particles. Clay Minerals 27, 137-158. 
Steiger, R.H., and Jager, E., 1977. Subcommission on geochronology: Convention on the use of decay constants in geo- and cosmochronology. Earth and Planetary Science Letters 36, $359-362$.

Szczerba, M., Derkowski, A., Kalinichev, A.G., and rodo , J., 2015. Molecular modeling of the effects of ${ }^{40} \mathrm{Ar}$ recoil in illite particles on their $\mathrm{K}-\mathrm{Ar}$ isotope dating. Geochimica et Cosmochimica Acta 159, 162-176.

Taylor, S.R., and McLennan, S.M., 1985. The Continental Crust: Its Composition and Evolution. Blackwell (Oxford), 312p.

Tournier, B., Liewig, N., Edel, J.B., and Montigny, R., 1999. Accordance between the K-Ar ages of authigenetic illites and the ages of magnetic overprinting: the case of Triassic sandstones in Alsace (eastern France). Comptes Rendus à l' Académie des Sciences, Série IIA $329,7-13$.

Uysal, I.T., and Golding, S.D., 2003. Rare earth element fractionation in authigenic illitesmectite from Late Permian clastic rocks, Bowen Basin, Australia: implications for physic-chemical environments of fluids during illitization. Chemical Geology 193, 167179.

Velde, B., and Renac, C., 1996. Smectite to illite conversion and K-Ar ages. Clay Minerals $31,25-32$.

Worden, R.H., and Matray, J.M., 1995. Cross formational flow in the Paris Basin. Basin Research 7, 53-66.

Worden, R.H., and Morad, S., 2000. Quartz cementation in oil field sandstones: a review of the key controversies. In: Worden, R.H. and Morad, S. (Eds.), Quartz Cementation in Sandstones, Wiley-Blackwell, Oxford, 1-20.

Worden, R.H., and Morad, S., 2003. Clay mineral cements in sandstones. International Association of Sedimentologists Special publication 34, Blackwell, 509p.

Wygrala, B.P., 1988. Integrated computer-aided basin modeling applied to analysis of 
hydrocarbon generation history in a Northern Italian oil field. Organic Geochemistry 13, 187-197.

Yates, D.M., and Rosenberg, P.E., 1996. Formation and stability of endmember illite: I. Solution equilibration experiments at $100-250^{\circ} \mathrm{C}$ and $\mathrm{Pv}$,soln. Geochimica et Cosmochimica Acta 60, 1873-1883.

Zheng, Y.F., 1993. Calculation of oxygen isotope fractionation in hydroxyl-bearing silicates. Earth and Planetary Science Letters 120, 247-263.

Ziegler, P.A., 1990. Geological Atlas of Western and Central Europe. Shell International Petroleum Meeting, The Hague. Distributed by Geological Society Publication House, Bath, 239p.

Zwingmann, H., Clauer, N., and Gaupp, R., 1999. Structure-related geochemical (REE) and isotopic (K-Ar, $\left.\mathrm{Rb}-\mathrm{Sr}, \delta^{18} \mathrm{O}\right)$ characteristics of clay minerals from Rotliegend sandstone reservoirs (Permian, northern Germany). Geochimica et Cosmochimica Acta 63, 28052823.

\section{Figure and table caption}

Figure 1. Map of the Paris Basin with the outcropping Buntsandstein (Lower Triassic) sedimentary horizon and the Hercynian basement. The enlargement shows the regional outline with the major structural features, the locations of the deep drilling EST433 and the ANDRA Underground Research Laboratory.

Figure 2. Polarized-light optical microscopy images of a thin section (30 $\mu \mathrm{m}$-thick) of the EST-5 sample (at $1958 \mathrm{~m}$ depth). A. Overgrowths on albite (dark arrow) and K-feldspar (white arrow) crystals. B. Sub-synchronous crystallization of quartz (dark arrow) and Kfeldspar (white arrow) overgrowths. C. and D. Quartz overgrowths. 
Figure 3. SEM photomicrographs of authigenic mineral features in the Triassic sandstones.

A. A euhedral quartz crystal associated with smaller quartz grains $(1-10 \mu \mathrm{m})$ and illite (sample EST-4). B. Diamond-shaped adularia (sample EST-5). C. Illite filaments and fibers growing on a partly dissolved K-feldspar grain (sample EST-4). D. Typical habitus of illite from Triassic sandstones: hairy illite growing onto well-crystallized hexagonal plates, suggesting that the hairy morphologies correspond to the last stage of the mineral paragenesis (sample EST-4). E. Platy and lathy illite (sample EST-2). F. Enlargement of platy to the left and lathy illite to the right (sample EST-2). G. A pyrite framboïd wrapped in illite fibers (sample EST-2). H. Pyrite as framboïds and euhedral crystals associated with illite (sample EST-3).

Figure 4. TEM photomicrographs of fine fractions from Triassic cored sandstone. A. Illite laths growing onto hexagonal plates (sample EST-3). B. Detailed microphotograph of the two morphologies: hexagonal plates (left) and laths (right) (sample EST-3). C. Illite laths (sample EST-2). D. Mixing of illite laths and plates (sample EST-4). E. Hexagonal illite overgrowths (arrow), together with some dispersed filaments (sample EST-2). F. Enlargement of a hexagonal illite overgrowth (arrow) (sample EST-2).

Figure 5. Sketch of the successive mineral parageneses based on SEM observations.

Figure 6. Crystal-chemical diagrams applied to illite analyses from Buntsandstein sandstones (TEM-EDS analyses). Pyr stands for pyrophyllite, Bei for beidellite, Mt for montmorillonite, Verm for vermiculite, Musc for muscovite, LC for low charge, and HC for high charge.

Figure 7. PAAS-normalized REE concentrations of each size fraction of the 6 studied samples from Triassic sandstones.

Figure 8. REE patterns of the leachates compared to the untreated corresponding illite-rich size fractions. 
Figure 9. (A) Combination of the binned histogram of the K-Ar ages and the probable density distribution based on the software AGEDISPLAY of Sircombe (2004) with the frequency and probability of the two representations. (B) ${ }^{40} \mathrm{Ar} /{ }^{36} \mathrm{Ar}$ vs. ${ }^{40} \mathrm{~K} /{ }^{36} \mathrm{Ar}$ isochron plot for the same nanometric illite-rich fractions; the first number of the data point identification refers to the sample number (EST-1 to EST-6), and then to the size of the separates from 1 for $<0.02 \mu \mathrm{m}$, to 2 for the $0.02-0.05 \mu \mathrm{m}$, and 3 for the $0.05-0.1 \mu \mathrm{m}$ intervals.

Figure 10. $\mathrm{Rb}-\mathrm{Sr}$ isochron plots of the three leached and untreated illite-rich size fractions of sample EST-1 in (A) and sample EST-2 in (B) with the ages and initial ${ }^{87} \mathrm{Sr}{ }^{86} \mathrm{Sr}$ ratio of the equilibrium line for each couple.

Figure 11. Modeled burial and thermal evolution pattern for the eastern Paris Basin (after Blaise et al., 2014). The decompacted burial of the whole sedimentary sequence is plotted relative to time on the horizontal scale and depth on the vertical scale. The stratigraphic succession starts to the left upper side with the bottom sedimentary units, which progressive burial can be followed by the varied curves. A reverse sedimentation is visible during about $10 \mathrm{Ma}$ around $40 \mathrm{Ma}$ ago. The color chart to the left of the pattern increases from blue to red color; the iso-temperatures curves of $50^{\circ} \mathrm{C}$ and $100^{\circ} \mathrm{C}$ are drafted in the pattern. The temperature records are based on the organic matter maturity and apatite fission track that basically require the use of thermal modeling inversion. Because no inversion procedure is currently available to model these two thermometers simultaneously, the PetroMod 11.0 model (Wygrala, 1988) for the organic matter and the AFTSolve model for fission track (Ketcham et al., 2000) were used.

Figure 12. Plot of K-Ar ages vs. $\delta^{18} \mathrm{O}$ for the studied size fractions of the six samples. White, grey and black symbols represent the $<0.02,0.02-0.05$ and $0.05-0.1 \mu \mathrm{m}$ size fractions, respectively. Full arrows illustrate the crystal growth mechanism (younger ages and lower ${ }^{18} \mathrm{O}$ contents), while dotted arrows correspond to a probable incomplete resetting of the $\mathrm{K}-\mathrm{Ar}$ clock of detrital micas or illite. 
Figure 13. Compilation of $\mathrm{K}-\mathrm{Ar}$ ages of authigenic illite in fine clay-sized fractions of sediments from the Paris Basin and covering the Central Massif: (1) outcropping Buntsandstein sandstones on and next to the border faults of the Vosges basement (ages of $<0.2 \mu \mathrm{m}$ fractions; Clauer et al., 2008); (2) and (2') Rhaetian (Upper Triassic) sandstones from two boreholes in the south-central Paris Basin (ages of $<0.2 \mu \mathrm{m}$ fractions; Mossmann et al., 1992; Clauer et al., 1995); (3) Illite and illite-smectite mixed layers as low-temperature alteration phases in the Bernardan U deposit (Patrier et al., 1997); (4) and (4') illite and illite-smectite mixed-layers at the sediment/basement interface (ages of $<2$ $\mu \mathrm{m}$ fractions; Cathelineau et al., 2012); (5) Clay-rich materials filling fractures in granites (ages of <0.2 m fractions; Cathelineau et al., 2004); (6) Upper Rotliegende (Permian) and Bunter sandstones (Lower Triassic) from outcrops in the High Rhine trough area (ages of $<0.2 \mu \mathrm{m}$ fractions; Brockamp et al., 2011); (7) this study (ages of $<0.02 \mathrm{~m}$ fractions). When given with $\mathrm{a} \pm$ error, the ages were obtained by an isochron display. The star “*” indicates consistent ages for adularia by ${ }^{40} \mathrm{Ar} /{ }^{39} \mathrm{Ar}$ dating.

Table 1. Characteristics of the investigated samples, and qualitative mineral composition of the studied size fractions. Ill stands for illite, I-S for illite-smectite mixed layer, C-S for chlorite-smectite (corrensite) mixed layer, Chl for chlorite, Kaol for kaolinite, Qtz for quartz, and K-spar for K-feldspar.

Table 2. Major and trace element contents of each size fraction of the six samples from Triassic sandstones. The major elements are expressed as oxides in wt.\% and the trace elements as $\mu \mathrm{g} / \mathrm{g}$. LOI stands for loss of ignition and bdl for below detection limit.

Table 3. Elemental analyses of the acid leachates of the three size fractions from EST-1 and EST-2 samples.

Table 4. K-Ar data and $\delta^{18} \mathrm{O}$ values of the different size fractions from the studied samples. 
Table 5. Rb-Sr data of the size fractions from EST-1 and EST-2 samples. 
Table 1

\begin{tabular}{|c|c|c|c|c|c|c|c|c|c|}
\hline $\begin{array}{l}\text { Sample } \\
\text { ID }\end{array}$ & $\begin{array}{c}\text { Stratigraphic } \\
\text { location }\end{array}$ & $\begin{array}{l}\text { Depth } \\
(\mathrm{m})\end{array}$ & $\begin{array}{l}\text { Size } \\
(\mu \mathrm{m})\end{array}$ & III & I-S & C-S & Chl & Kaol & Acc Min \\
\hline EST-1 & $\begin{array}{c}\text { Buntsandstein } \\
\text { (= Lower } \\
\text { Triassic) }\end{array}$ & 1825 & $\begin{array}{c}<0.02 \\
0.02-0.05 \\
0.05-0.1\end{array}$ & $\begin{array}{l}+++ \\
+++ \\
+++\end{array}$ & $\begin{array}{l}+ \\
+ \\
+\end{array}$ & + & + & & $\begin{array}{l}\text { Qtz } \\
\text { Qtz } \\
\text { Qtz }\end{array}$ \\
\hline EST-2 & Buntsandstein & 1882 & $\begin{array}{c}<0.02 \\
0.02-0.05 \\
0.05-0.1\end{array}$ & $\begin{array}{l}+++ \\
+++ \\
+++\end{array}$ & $\begin{array}{l}+ \\
+\end{array}$ & & + & & $\begin{array}{l}\text { Qtz } \\
\text { Qtz } \\
\text { Qtz }\end{array}$ \\
\hline EST-3 & Buntsandstein & 1887 & $\begin{array}{c}<0.02 \\
0.02-0.05 \\
0.05-0.1 \\
\end{array}$ & $\begin{array}{l}+++ \\
+++ \\
+++\end{array}$ & $\begin{array}{l}+ \\
+ \\
+\end{array}$ & & $\begin{array}{l}+ \\
+\end{array}$ & & $\begin{array}{c}\text { Qtz } \\
\text { Qtz } \\
\text { Qtz, K-spar }\end{array}$ \\
\hline EST-4 & Buntsandstein & 1952 & $\begin{array}{c}<0.02 \\
0.02-0.05 \\
0.05-0.1 \\
\end{array}$ & $\begin{array}{l}+++ \\
+++ \\
+++\end{array}$ & $\begin{array}{l}+ \\
+\end{array}$ & & + & & $\begin{array}{l}\text { Qtz } \\
\text { Qtz } \\
\text { Qtz }\end{array}$ \\
\hline EST-5 & Buntsandstein & 1958 & $\begin{array}{c}<0.02 \\
0.02-0.05 \\
0.05-0.1 \\
\end{array}$ & $\begin{array}{l}+++ \\
+++ \\
+++\end{array}$ & $\begin{array}{l}+ \\
+ \\
+\end{array}$ & & + & & $\begin{array}{c}\text { Qtz } \\
\text { Qtz, K-spar } \\
\text { Qtz, K-spar }\end{array}$ \\
\hline EST-6 & Buntsandstein & 1999 & $\begin{array}{c}<0.02 \\
0.02-0.05 \\
0.05-0.1\end{array}$ & $\begin{array}{l}+++ \\
+++ \\
+++\end{array}$ & $\begin{array}{l}+ \\
+ \\
+\end{array}$ & & $\begin{array}{c}+ \\
+ \\
++\end{array}$ & $\begin{array}{c}+ \\
+ \\
++\end{array}$ & $\begin{array}{l}\text { Qtz } \\
\text { Qtz } \\
\text { Qtz }\end{array}$ \\
\hline
\end{tabular}

Acc Min stands for accessory minerals, III for illite, I-S for illite-smectite mixed-layer, C-S for chlorite-smectite mixed-layer, Chl for chlorite, Kaol for kaolinite, Qtz for quartz and K-Spar for K-feldspar, +++ for dominant,++ for intermediate, + for low contents 


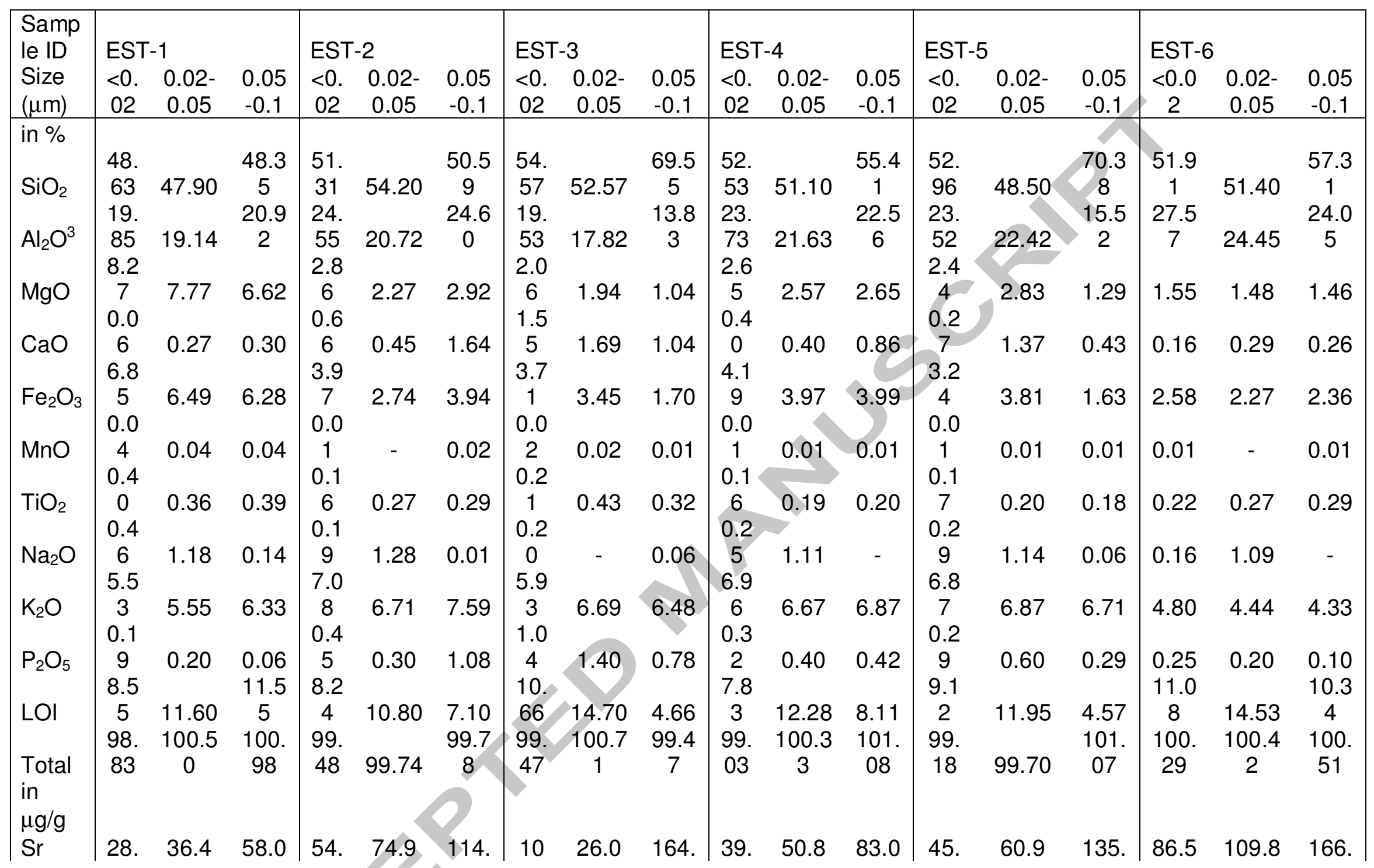




\begin{tabular}{|c|c|c|c|c|c|c|c|c|c|c|c|c|c|c|c|c|c|c|}
\hline \multirow[b]{3}{*}{$\mathrm{Ba}$} & 5 & & & 4 & & 0 & 1.7 & & 0 & 6 & & & 7 & & 0 & & & 0 \\
\hline & 12 & & 224. & 10 & & 200. & 24 & & 618. & 99. & & 204. & 152 & & 593. & & & 200. \\
\hline & $\begin{array}{l}0.1 \\
30 .\end{array}$ & 165.7 & 0 & $\begin{array}{l}4.7 \\
23 .\end{array}$ & 255.9 & 0 & $\begin{array}{l}7.5 \\
32 .\end{array}$ & 69.0 & 0 & $\begin{array}{c}8 \\
9.1\end{array}$ & 139.0 & 0 & $\begin{array}{r}.2 \\
13 .\end{array}$ & 127.7 & 0 & 96.6 & 196.2 & 0 \\
\hline Co & 4 & 31.4 & 21.0 & 3 & 10.6 & 19.0 & 3 & 4.00 & 15.0 & 0 & 8.60 & 8.00 & 7 & 23.7 & 7.00 & 6.80 & 6.40 & 8.00 \\
\hline & 78. & & & 11 & & 140. & 13 & & & 56. & & & 80. & & & & & \\
\hline $\mathrm{Cr}$ & $\begin{array}{c}0 \\
20 .\end{array}$ & 109.0 & 97.0 & $\begin{array}{l}6.0 \\
10\end{array}$ & 90.0 & 0 & $\begin{array}{l}9.0 \\
60 .\end{array}$ & 96.0 & 88.0 & 0 & 72.0 & 66.0 & $\begin{array}{c}0 \\
40 .\end{array}$ & 134.0 & 77.0 & 59.0 & 81.0 & 91.0 \\
\hline $\mathrm{Cu}$ & $\begin{array}{c}0 \\
54 .\end{array}$ & 44.0 & 30.0 & $\begin{array}{l}0.0 \\
21 .\end{array}$ & 61.0 & 69.0 & $\begin{array}{c}0 \\
28 .\end{array}$ & 3.00 & 31.0 & $\overline{26 .}$ & 53.0 & 11.0 & $\begin{array}{c}0 \\
33 .\end{array}$ & 98.0 & 49.0 & 50.0 & 117.0 & 40.0 \\
\hline $\mathrm{Ni}$ & $\begin{array}{c}7 \\
79 .\end{array}$ & 81.9 & 55.0 & $\begin{array}{c}2 \\
20\end{array}$ & 52.3 & $\begin{array}{l}60.0 \\
241 .\end{array}$ & $\begin{array}{c}5 \\
19\end{array}$ & 10.0 & $\begin{array}{l}47.0 \\
108 .\end{array}$ & $\begin{array}{c}8 \\
10\end{array}$ & 36.4 & $\begin{array}{l}28.0 \\
114 .\end{array}$ & $\begin{array}{c}5 \\
106\end{array}$ & 39.4 & 39.0 & 42.1 & 63.9 & 47.0 \\
\hline V & $\begin{array}{c}5 \\
11 .\end{array}$ & 96.1 & 97.8 & $\begin{array}{l}9.0 \\
35 .\end{array}$ & 143.6 & 0 & $\begin{array}{l}2.1 \\
47 .\end{array}$ & 34.7 & 0 & $\begin{array}{l}4.5 \\
15 .\end{array}$ & 125.1 & & $\begin{array}{c}.0 \\
8.9\end{array}$ & 234.1 & 67.9 & 54.2 & 70.6 & 62.7 \\
\hline Y & $\begin{array}{c}9 \\
10\end{array}$ & 15.7 & $\begin{array}{l}22.4 \\
140 .\end{array}$ & $\begin{array}{c}8 \\
80 .\end{array}$ & 13.9 & 76.1 & $\begin{array}{c}4 \\
70 .\end{array}$ & 12.5 & 55.8 & $\begin{array}{c}9 \\
50 .\end{array}$ & 22.6 & 34.5 & $\begin{array}{c}0 \\
40 .\end{array}$ & 39.0 & 19.7 & 38.1 & 51.1 & $\begin{array}{l}78.3 \\
230 .\end{array}$ \\
\hline $\mathrm{Zn}$ & $\begin{array}{l}0.0 \\
46 .\end{array}$ & 195.0 & 0 & $\begin{array}{c}0 \\
47 .\end{array}$ & 104.0 & 90.0 & $\begin{array}{c}0 \\
47 .\end{array}$ & 450.0 & 60.0 & $\begin{array}{c}0 \\
25 .\end{array}$ & 139.0 & 90.0 & $\begin{array}{c}0 \\
26 .\end{array}$ & 161.0 & - & $\begin{array}{l}70.0 \\
149 .\end{array}$ & 165.0 & $\begin{array}{c}0 \\
291 .\end{array}$ \\
\hline $\mathrm{Zr}$ & $\begin{array}{c}0 \\
16\end{array}$ & 72.0 & $\begin{array}{l}78.0 \\
251 .\end{array}$ & $\begin{array}{c}0 \\
17\end{array}$ & 38.0 & $\begin{array}{l}90.0 \\
237 .\end{array}$ & $\begin{array}{c}0 \\
15\end{array}$ & 6.00 & $\begin{array}{l}69.0 \\
200 .\end{array}$ & $\begin{array}{c}0 \\
14\end{array}$ & 39.0 & $\begin{array}{l}46.0 \\
215 .\end{array}$ & $\begin{array}{c}0 \\
164\end{array}$ & 62.0 & $\begin{array}{l}42.0 \\
229 .\end{array}$ & 0 & 231.0 & $\begin{array}{c}0 \\
140 .\end{array}$ \\
\hline $\mathrm{Rb}$ & $\begin{array}{l}3.0 \\
4.7\end{array}$ & 217.2 & 0 & $\begin{array}{l}0.3 \\
2.0\end{array}$ & 192.1 & 0 & $\begin{array}{l}2.9 \\
3.3\end{array}$ & 31.8 & 0 & $\begin{array}{l}7.8 \\
1.7\end{array}$ & 192.9 & 0 & $\begin{array}{c}.3 \\
1.7\end{array}$ & 198.5 & 0 & 95.6 & 126.3 & 0 \\
\hline $\mathrm{Nb}$ & $\begin{array}{c}3 \\
4.8\end{array}$ & 6.39 & 7.95 & $\begin{array}{r}7 \\
21 .\end{array}$ & 2.31 & 5.67 & $\begin{array}{c}8 \\
24 .\end{array}$ & 0.91 & 6.49 & $\begin{array}{c}9 \\
6.3\end{array}$ & 2.60 & 3.96 & $\begin{array}{c}1 \\
18 .\end{array}$ & 2.69 & 3.76 & 2.48 & 4.63 & 5.89 \\
\hline Sn & $\begin{array}{c}0 \\
1.7\end{array}$ & 9.70 & 6.70 & $\begin{array}{c}5 \\
0.9\end{array}$ & 29.0 & 27.6 & $\begin{array}{c}2 \\
0.8\end{array}$ & & 16.3 & $\begin{array}{c}0 \\
1.1\end{array}$ & 14.1 & 9.40 & $\begin{array}{c}2 \\
1.0\end{array}$ & 27.1 & 36.5 & 5.80 & 13.0 & 9.10 \\
\hline $\mathrm{Sb}$ & $\begin{array}{c}0 \\
35 .\end{array}$ & 2.50 & 3.20 & $\begin{array}{c}0 \\
28 .\end{array}$ & 1.10 & 1.70 & $\begin{array}{c}0 \\
20 .\end{array}$ & & 0.80 & $\begin{array}{c}0 \\
20 .\end{array}$ & 1.20 & 1.80 & $\begin{array}{c}0 \\
21 .\end{array}$ & 1.10 & 0.40 & 4.90 & 2.90 & 7.80 \\
\hline Cs & $\begin{array}{c}2 \\
1.5\end{array}$ & 26.5 & 52.6 & $\begin{array}{c}8 \\
1.7\end{array}$ & 13.8 & 0.0 & $\begin{array}{c}4 \\
1.8\end{array}$ & 3.78 & 17.1 & $\begin{array}{c}8 \\
0.9\end{array}$ & 15.4 & 30.6 & $\begin{array}{c}1 \\
1.0\end{array}$ & 19.5 & 20.1 & 15.3 & 11.6 & 22.7 \\
\hline $\mathrm{H}$ & 1 & 2.25 & 2.67 & 7 & 1.28 & 3.23 & 4 & 0. & 2.66 & 5 & 1.5 & 2.03 & & 2.2 & 1.62 & 4.89 & 7.20 & 10.1 \\
\hline $\mathrm{a}$ & 0.5 & 1.27 & 0.74 & 0.2 & 0.50 & 0.56 & 0.3 & 0.07 & 0.84 & 0.2 & 0.38 & 0.50 & 0.4 & 0.32 & 0.53 & 0.40 & 1.14 & 0.74 \\
\hline
\end{tabular}




\begin{tabular}{|c|c|c|c|c|c|c|c|c|c|c|c|c|c|c|c|c|c|c|}
\hline & $\begin{array}{r}2 \\
20\end{array}$ & & & $\begin{array}{r}2 \\
30\end{array}$ & & & $\begin{array}{r}5 \\
12\end{array}$ & & & 7 & & & $\begin{array}{r}2 \\
12\end{array}$ & & & & & \\
\hline $\mathrm{Pb}$ & $\begin{array}{c}29 . \\
2 \\
12\end{array}$ & 38.7 & 22.6 & $\begin{array}{c}30 . \\
8 \\
13\end{array}$ & 16.4 & 34.6 & $\begin{array}{c}43 . \\
9 \\
9\end{array}$ & - & 22.8 & $\begin{array}{c}14 . \\
6 \\
82\end{array}$ & 15.3 & 19.3 & $\begin{array}{c}13 . \\
1 \\
80\end{array}$ & 21.3 & 4.30 & 27.1 & 12.7 & 35.2 \\
\hline Th & $\begin{array}{c}12 . \\
5 \\
2.5\end{array}$ & 14.8 & 14.5 & $\begin{array}{c}13 . \\
3 \\
7.5\end{array}$ & 10.2 & 26.0 & $\begin{array}{c}20 . \\
2 \\
8.1\end{array}$ & 4.80 & 21.3 & $\begin{array}{c}8.2 \\
0 \\
4.5\end{array}$ & 10.7 & 15.0 & $\begin{array}{c}8.0 \\
0 \\
7.3\end{array}$ & 18.0 & 9.40 & 10.3 & 15.6 & 21.6 \\
\hline $\begin{array}{l}\text { U } \\
\text { in }\end{array}$ & 9 & 3.14 & 3.22 & 8 & 5.56 & 9.43 & 4 & 1.85 & 8.75 & 4 & 4.65 & 5.21 & 6 & 7.81 & & 4.81 & 6.61 & 9.49 \\
\hline$\mu \mathrm{g} / \mathrm{g}$ & $\begin{array}{c}16 . \\
2\end{array}$ & 26.3 & 33.5 & $\begin{array}{c}19 . \\
7\end{array}$ & 205 & 446 & $\begin{array}{c}31 . \\
9\end{array}$ & 858 & 453 & $\begin{array}{c}12 . \\
6\end{array}$ & 229 & 306 & $\begin{array}{c}10 . \\
1\end{array}$ & 27.1 & 251 & 1 & ?2? & 284 \\
\hline & 39. & & & 50. & 20.0 & 115. & 86. & 0.00 & 115. & 34. & 2 L.J & & 22. & & 20.1 & L. & 2.2. & 20.1 \\
\hline $\mathrm{Ce}$ & $\begin{array}{c}1 \\
5.3\end{array}$ & 58.9 & 71.4 & $\begin{array}{c}4 \\
5.0\end{array}$ & 43.7 & 0 & $\begin{array}{c}9 \\
8.2\end{array}$ & 22.2 & 0 & $\begin{array}{c}3 \\
3.3\end{array}$ & 56.6 & 78.5 & $\begin{array}{c}4 \\
2.4\end{array}$ & 67.6 & 55.9 & 22.2 & 38.1 & 49.2 \\
\hline $\operatorname{Pr}$ & $\begin{array}{c}4 \\
24\end{array}$ & 7.82 & 9.54 & $\begin{array}{c}4 \\
22 .\end{array}$ & 4.81 & 12.3 & $\begin{array}{c}5 \\
36 .\end{array}$ & 2.27 & 12.0 & $\begin{array}{c}0 \\
13 .\end{array}$ & 5.37 & 7.79 & $\begin{array}{c}4 \\
9.5\end{array}$ & 6.83 & 6.48 & 2.63 & 4.54 & 5.99 \\
\hline $\mathrm{Nd}$ & $\begin{array}{c}9 \\
5.8\end{array}$ & 35.7 & 40.5 & $\begin{array}{c}7 \\
8.0\end{array}$ & 18.8 & 55.4 & $\begin{array}{c}2 \\
12 .\end{array}$ & 9.78 & 50.2 & $\begin{array}{c}9 \\
3.8\end{array}$ & 21.8 & 32.0 & $\begin{array}{c}9 \\
2.3\end{array}$ & 31.1 & 35.8 & 9.89 & 16.8 & 22.4 \\
\hline Sm & $\begin{array}{c}6 \\
1.0\end{array}$ & 1.72 & 8.58 & $\begin{array}{c}8 \\
2.3\end{array}$ & 4.19 & 21.1 & $\begin{array}{c}8 \\
3.5\end{array}$ & 3.31 & 15.5 & $\begin{array}{c}5 \\
1.0\end{array}$ & 5.51 & 8.40 & $\begin{array}{c}8 \\
0.6\end{array}$ & 10.8 & 5.72 & 2.24 & 3.72 & 4.86 \\
\hline Eu & $\begin{array}{c}7 \\
4.2\end{array}$ & 1.46 & 1.46 & $\begin{array}{c}0 \\
10 .\end{array}$ & 1.01 & 5.72 & $\begin{array}{c}4 \\
15 .\end{array}$ & 0.85 & 3.87 & $\begin{array}{c}2 \\
4.2\end{array}$ & 1.47 & 2.06 & $\begin{array}{c}4 \\
2.3\end{array}$ & 3.28 & 1.35 & 0.66 & 1.10 & 1.38 \\
\hline Gd & $\begin{array}{c}6 \\
0.5\end{array}$ & 5.69 & 5.80 & $\begin{array}{c}2 \\
1.4\end{array}$ & 3.78 & 22.9 & $\begin{array}{c}4 \\
2.1\end{array}$ & 3.40 & 15.8 & $\begin{array}{c}6 \\
0.6\end{array}$ & 6.08 & 8.21 & $\begin{array}{c}1 \\
0.3\end{array}$ & 13.8 & 4.54 & 3.13 & 4.96 & 6.40 \\
\hline $\mathrm{Tb}$ & $\begin{array}{c}5 \\
2.8\end{array}$ & 0.67 & 0.85 & $\begin{array}{c}4 \\
7.6\end{array}$ & 0.45 & 3.68 & $\begin{array}{c}9 \\
11 .\end{array}$ & & 2.52 & $\begin{array}{c}6 \\
3.6\end{array}$ & 0.88 & 1.37 & $\begin{array}{c}4 \\
1.9\end{array}$ & 1.99 & 0.69 & 0.72 & 1.14 & 1.68 \\
\hline Dy & $\begin{array}{c}4 \\
0.4\end{array}$ & 3.89 & 4.66 & $\begin{array}{c}8 \\
1.3\end{array}$ & 3.10 & 18.6 & $\begin{array}{c}3 \\
1.8\end{array}$ & & 13.3 & $\begin{array}{c}7 \\
0.6\end{array}$ & 5.21 & 7.63 & $\begin{array}{c}3 \\
0.3\end{array}$ & 10.2 & 3.79 & 5.51 & 8.90 & 12.7 \\
\hline Ho & $\begin{array}{c}7 \\
1.3\end{array}$ & 0.71 & 0.91 & $\begin{array}{c}1 \\
3.4\end{array}$ & 0.59 & 3.29 & $\begin{array}{c}0 \\
4.4\end{array}$ & 0.49 & 2.38 & $\begin{array}{c}3 \\
1.7\end{array}$ & 0.95 & 1.44 & $\begin{array}{c}3 \\
0.9\end{array}$ & 1.75 & 0.72 & 1.29 & 2.08 & 3.10 \\
\hline Er & 5 & 1.97 & 2.37 & 1 & 1.57 & 7.37 & 9 & 1.08 & 5.44 & 3 & 2.50 & 3.37 & 9 & 9 & 1.83 & 4.62 & 7.2 & 9.30 \\
\hline $\mathrm{m}$ & 0.1 & 0.28 & 0.40 & 0.4 & 0.22 & 1.11 & 0.5 & 0.16 & 0.83 & 0.2 & 0.33 & 0.52 & 0.1 & 0.57 & 0.28 & 0.78 & 1.17 & 1.85 \\
\hline
\end{tabular}




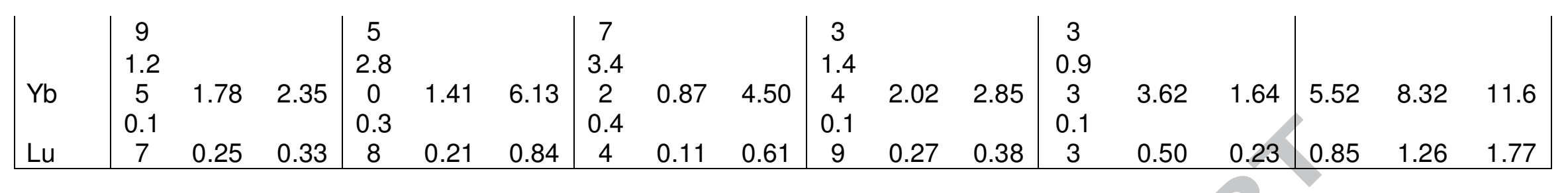


Table 3

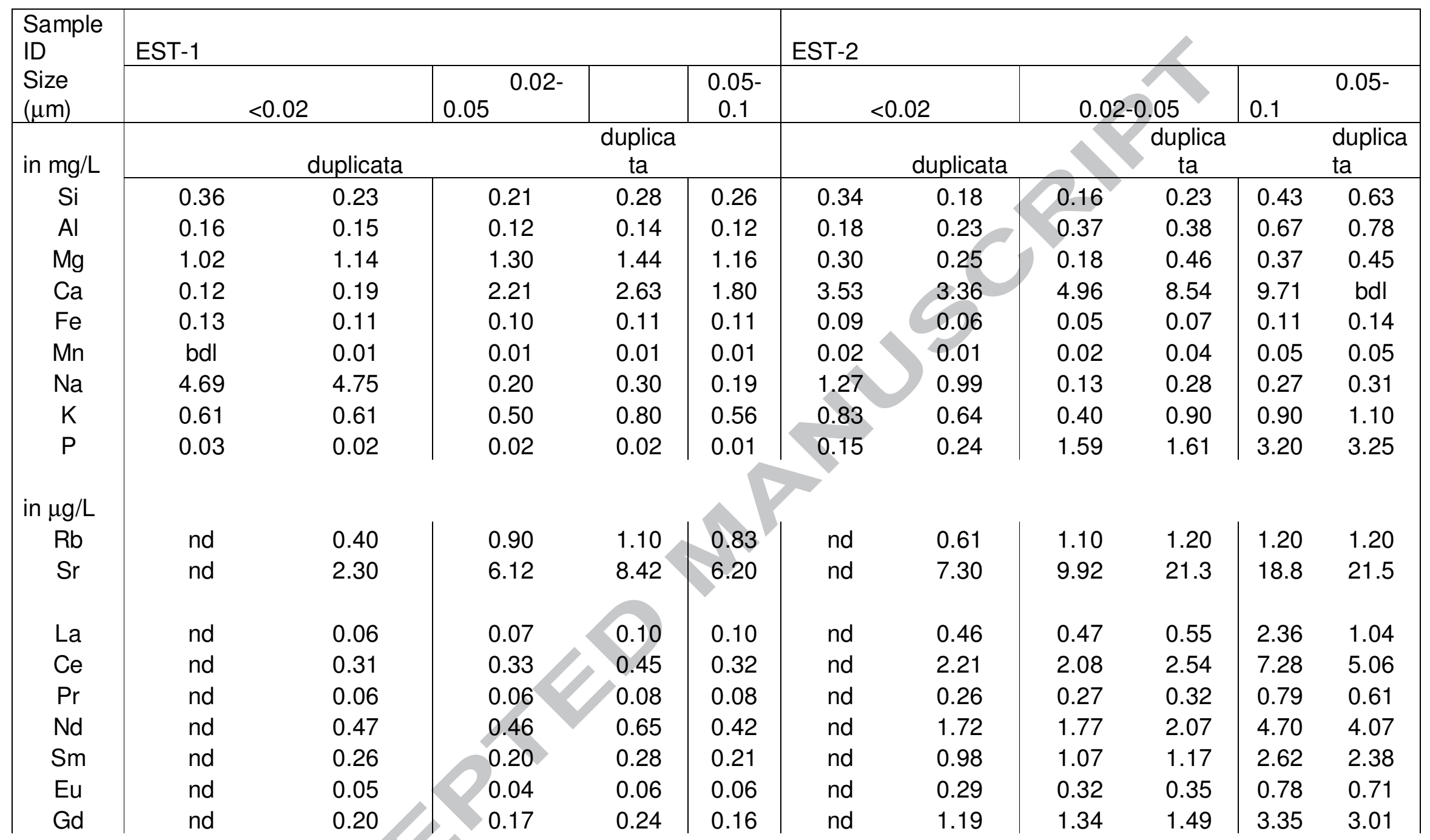




\begin{tabular}{|c|c|c|c|c|c|c|c|c|c|c|c|}
\hline Tb & nd & 0.02 & 0.01 & 0.02 & 0.03 & nd & 0.15 & 0.17 & 0.19 & 0.43 & 0.38 \\
\hline Dy & nd & 0.09 & 0.06 & 0.09 & 0.07 & nd & 0.71 & 0.80 & 0.93 & 1.99 & 1.88 \\
\hline Ho & nd & 0.01 & bdl & 0.01 & 0.02 & nd & 0.11 & 0.12 & 0.14 & 0.30 & 0.29 \\
\hline $\mathrm{Er}$ & nd & 0.02 & 0.02 & 0.02 & 0.03 & nd & 0.25 & 0.27 & 0.33 & 0.72 & 0.68 \\
\hline Tm & nd & bdl & bdl & bdl & 0.01 & nd & 0.03 & 0.03 & 0.04 & 0.08 & 0.07 \\
\hline $\mathrm{Yb}$ & nd & 0.01 & bdl & 0.01 & 0.02 & nd & 0.16 & 0.20 & 0.25 & 0.48 & 0.46 \\
\hline $\mathrm{Lu}$ & nd & bdl & bdl & bdl & 0.01 & nd & 0.02 & 0.03 & 0.03 & 0.07 & 0.07 \\
\hline
\end{tabular}

nd stands for not determined 


\begin{tabular}{|c|c|c|c|c|c|c|c|c|c|}
\hline $\begin{array}{l}\text { Sample } \\
\text { ID }\end{array}$ & $\begin{array}{l}\text { Depth } \\
(\mathrm{m})\end{array}$ & $\begin{array}{l}\text { Size } \\
(\mu \mathrm{m})\end{array}$ & $\begin{array}{l}\mathrm{K} \\
(\%)\end{array}$ & $\begin{array}{l}\text { rad. Ar } \\
(\%)\end{array}$ & $\begin{array}{c}\mathrm{rad} .{ }^{40} \mathrm{Ar} \\
\left(10^{-9}\right. \\
\mathrm{mol} / \mathrm{g})\end{array}$ & 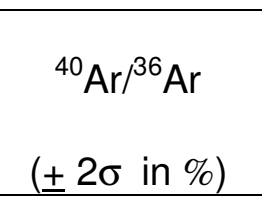 & $\begin{array}{c}{ }^{40} \mathrm{~K} /{ }^{36} \mathrm{Ar} \\
\left(10^{-6} \pm 2 \sigma \text { in }\right. \\
\%)\end{array}$ & $\begin{array}{c}\text { Age } \\
(\mathrm{Ma} \pm 2 \sigma)\end{array}$ & $\begin{array}{c}\delta^{18} \mathrm{O} \\
\text { (V-SMOW) }\end{array}$ \\
\hline \multirow[t]{3}{*}{ EST-1 } & \multirow[t]{3}{*}{1825} & $<0.02$ & 4.58 & 89.46 & 1.514 & $2885.7(1.18)$ & $0.2339(2.36)$ & $181.2(3.7)$ & $18.1(0.2)$ \\
\hline & & $0.02-0.05$ & 5.34 & 90.67 & 1.691 & $3349.1(2.20)$ & 0.2879 (3.02) & $173.9(3.7)$ & $18.0(0.2)$ \\
\hline & & $0.05-0.1$ & 5.25 & 90.86 & 1.887 & $3395.0(2.01)$ & $0.2575(2.85)$ & $196.1(4.1)$ & $17.6(0.2)$ \\
\hline \multirow[t]{3}{*}{ EST-2 } & \multirow[t]{3}{*}{1882} & $<0.02$ & 5.87 & 93.03 & 1.623 & $4439.6(2.18)$ & $0.4473(2.98)$ & 152.7 (3.2) & $18.2(0.2)$ \\
\hline & & $0.02-0.05$ & 6.54 & 94.22 & 1.751 & $5484.0(2.92)$ & $0.5784(3.09)$ & $148.1(3.1)$ & $17.9(0.2)$ \\
\hline & & $0.05-0.1$ & 6.26 & 93.78 & 1.914 & $5084.3(1.58)$ & $0.4676(2.56)$ & $168.2(3.5)$ & $17.3(0.2)$ \\
\hline \multirow[t]{3}{*}{ EST-3 } & \multirow[t]{3}{*}{1887} & $<0.02$ & 4.96 & 90.00 & 1.673 & $3072.0(1.38)$ & $0.2457(2.46)$ & 184.7 (3.8) & nd \\
\hline & & $0.02-0.05$ & 5.55 & 89.30 & 1.803 & $2925.5(2.42)$ & $0.2416(3.18)$ & 184.7 (3.8) & nd \\
\hline & & $0.05-0.1$ & 5.41 & 91.82 & 2.167 & $3813.1(1.13)$ & $0.2622(2.31)$ & $217.3(4.5)$ & $15.2(0.2)$ \\
\hline \multirow[t]{3}{*}{ EST-4 } & \multirow[t]{3}{*}{1952} & $<0.02$ & 5.75 & 91.03 & 1.575 & $3380.0(1.03)$ & $0.3362(2.28)$ & $151.4(3.1)$ & $17.2(0.2)$ \\
\hline & & $0.02-0.05$ & 6.09 & 92.60 & 1.603 & $4333.3(2.57)$ & $0.4580(3.26)$ & 145.7 (3.0) & $17.0(0.2)$ \\
\hline & & $0.05-0.1$ & 5.66 & 91.57 & 1.730 & $3660.6(1.57)$ & $0.3287(2.56)$ & $168.1(3.5)$ & $16.8(0.2)$ \\
\hline \multirow[t]{3}{*}{ EST-5 } & \multirow[t]{3}{*}{1958} & $<0.02$ & 5.63 & 92.11 & 1.529 & $3951.7(1.48)$ & $0.4019(2.52)$ & $150.1(3.1)$ & nd \\
\hline & & $0.02-0.05$ & 6.23 & 92.57 & 1.715 & $4392.3(2.72)$ & $0.4442(3.38)$ & $152.1(3.1)$ & $16.1(0.2)$ \\
\hline & & $0.05-0.1$ & 5.61 & 94.57 & 2.156 & $5940.4(1.78)$ & 0.4384 (2.69) & $209.0(4.3)$ & $14.9(0.2)$ \\
\hline \multirow[t]{3}{*}{ EST-6 } & \multirow[t]{3}{*}{1999} & $<0.02$ & 4.14 & 88.65 & 1.104 & $2710.0(1.54)$ & $0.2702(2.56)$ & $147.6(3.1)$ & $16.3(0.2)$ \\
\hline & & $0.02-0.05$ & nd & 110 & nd & nd & nd & nd & $15.9(0.2)$ \\
\hline & & $0.05-0.1$ & 3.59 & 84.23 & 0.957 & $1991.0(1.86)$ & $0.1898(2.75)$ & $147.5(3.1)$ & $16.0(0.2)$ \\
\hline
\end{tabular}

nd stands for not determined; the $2 \sigma$ error of the $\mathrm{K}$ determinations is at $+/-2.5 \%$ 
Table 5

\begin{tabular}{|c|c|c|c|c|c|c|c|c|c|c|}
\hline Sample ID & Depth (m) & \multicolumn{2}{|c|}{ Fractions } & $\mathrm{Rb}$ & $\mathrm{Sr}$ & $\mathrm{Rb} / \mathrm{Sr}$ & ${ }^{8 /} \mathrm{Rb} /{ }^{86} \mathrm{Sr}$ & ${ }^{87} \mathrm{Sr} /{ }^{86} \mathrm{Sr}\left( \pm 2 \sigma\right.$ in $\left.10^{-6}\right)$ & $\mathrm{Rb}-\mathrm{Sr}$ age $(\mathrm{Ma}+2 \sigma)$ & ${ }^{87} \mathrm{Sr}^{86} \mathrm{Sr}_{\mathrm{o}}(+2 \sigma)$ \\
\hline \multirow[t]{6}{*}{ EST-1 } & \multirow[t]{6}{*}{1825} & \multirow[t]{2}{*}{$<0.02 \mu \mathrm{m}$} & leachate & 0.40 & 2.30 & 0.17 & 0.51 & $0.714428(66)$ & \multirow[t]{2}{*}{$148(8)$} & \multirow[t]{2}{*}{$0.7134(0.0003)$} \\
\hline & & & untreated & 163 & 28.5 & 5.72 & 16.6 & $0.748169(80)$ & & \\
\hline & & \multirow[t]{2}{*}{$0.02-0.05 \mu \mathrm{m}$} & leachate & 0.90 & 6.12 & 0.15 & 0.43 & $0.713651(26)$ & $134(7)$ & \multirow[t]{2}{*}{$0.7128(0.0002)$} \\
\hline & & & untreated & 217 & 36.4 & 5.96 & 17.3 & $0.745415(28)$ & & \\
\hline & & \multirow[t]{2}{*}{$0.05-0.1 \mu \mathrm{m}$} & leachate & 0.83 & 6.20 & 0.13 & 0.39 & 0.713953 (27) & $176(10)$ & \multirow[t]{2}{*}{$0.7130(0.0002)$} \\
\hline & & & untreated & 251 & 58.0 & 4.33 & 12.6 & $0.744088(11)$ & & \\
\hline \multirow[t]{6}{*}{ EST-2 } & \multirow[t]{6}{*}{1882} & \multirow[t]{2}{*}{$<0.02 \mu \mathrm{m}$} & leachate & 0.61 & 7.30 & 0.08 & 0.24 & 0.711307 (14) & $148(8)$ & \multirow[t]{2}{*}{$0.7108(0.0001)$} \\
\hline & & & untreated & 170 & 54.4 & 3.13 & 9.11 & $0.729824(10)$ & & \\
\hline & & \multirow[t]{2}{*}{$0.02-0.05 \mu \mathrm{m}$} & leachate & 1.10 & 9.92 & 0.11 & 0.32 & $0.712249(07)$ & $148(8)$ & \multirow[t]{2}{*}{$0.7116(0.0002)$} \\
\hline & & & untreated & 192 & 74.9 & 2.56 & 7.46 & $0.727553(07)$ & & \\
\hline & & \multirow[t]{2}{*}{$0.05-0.1 \mu \mathrm{m}$} & leachate & 1.20 & 18.8 & 0.06 & 0.19 & $0.712906(15)$ & $148(8)$ & \multirow[t]{2}{*}{$0.7125(0.0001)$} \\
\hline & & & untreated & 237 & 114 & 2.08 & 6.05 & 0.725047 (16) & & \\
\hline
\end{tabular}

The $\mathrm{Rb}-\mathrm{Sr}$ age is obtained by combining the data of each leachate and untreated couple. The initial $87 \mathrm{Sr} / 86 \mathrm{Sr}$ ratio of the line is given by ${ }^{87} \mathrm{Sr} /{ }^{86} \mathrm{Sr} \mathrm{r}_{0}$ 


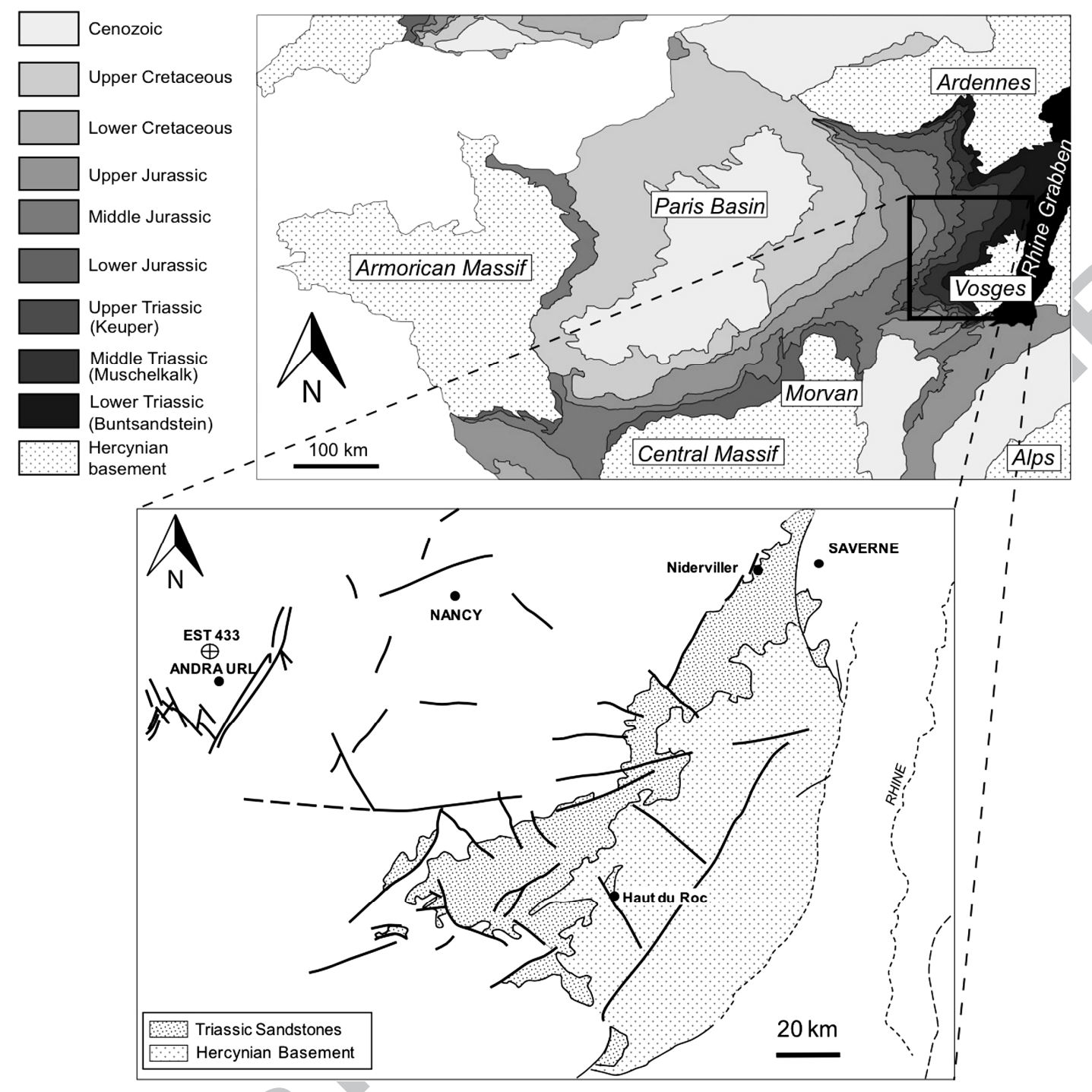




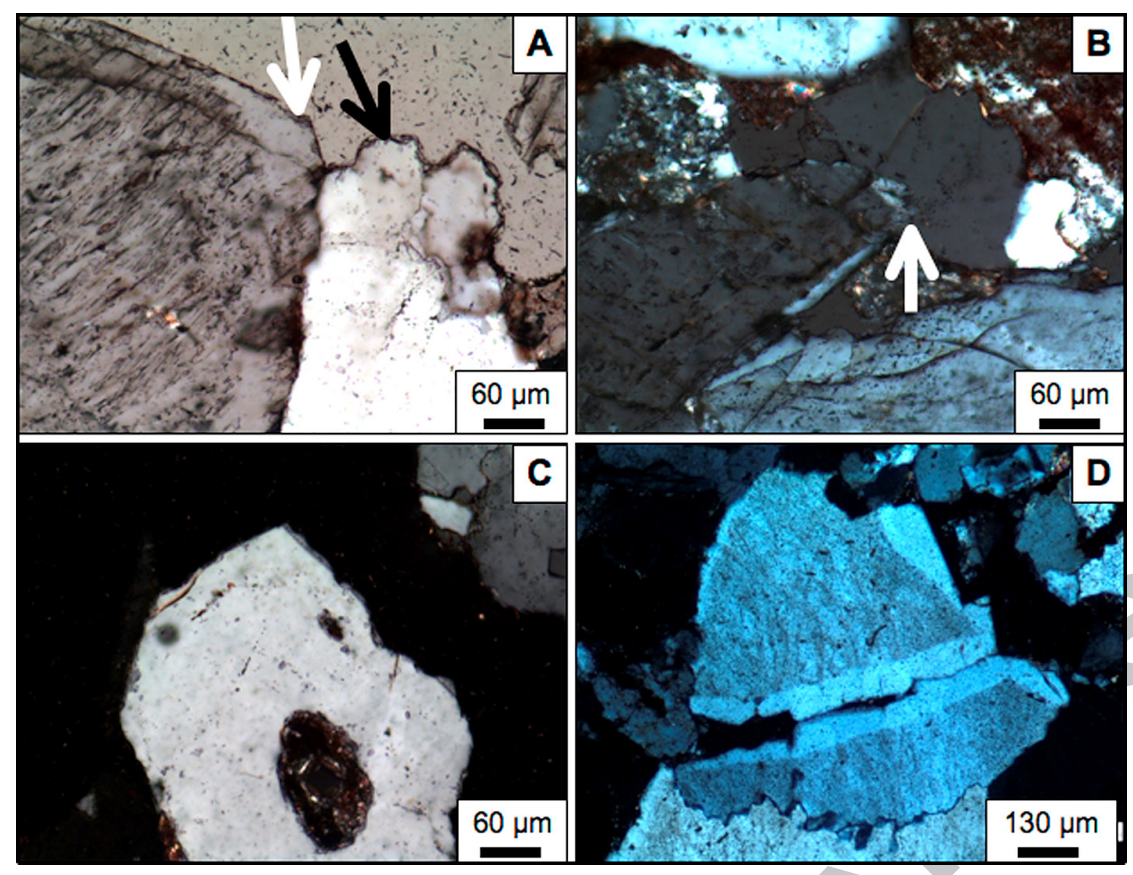



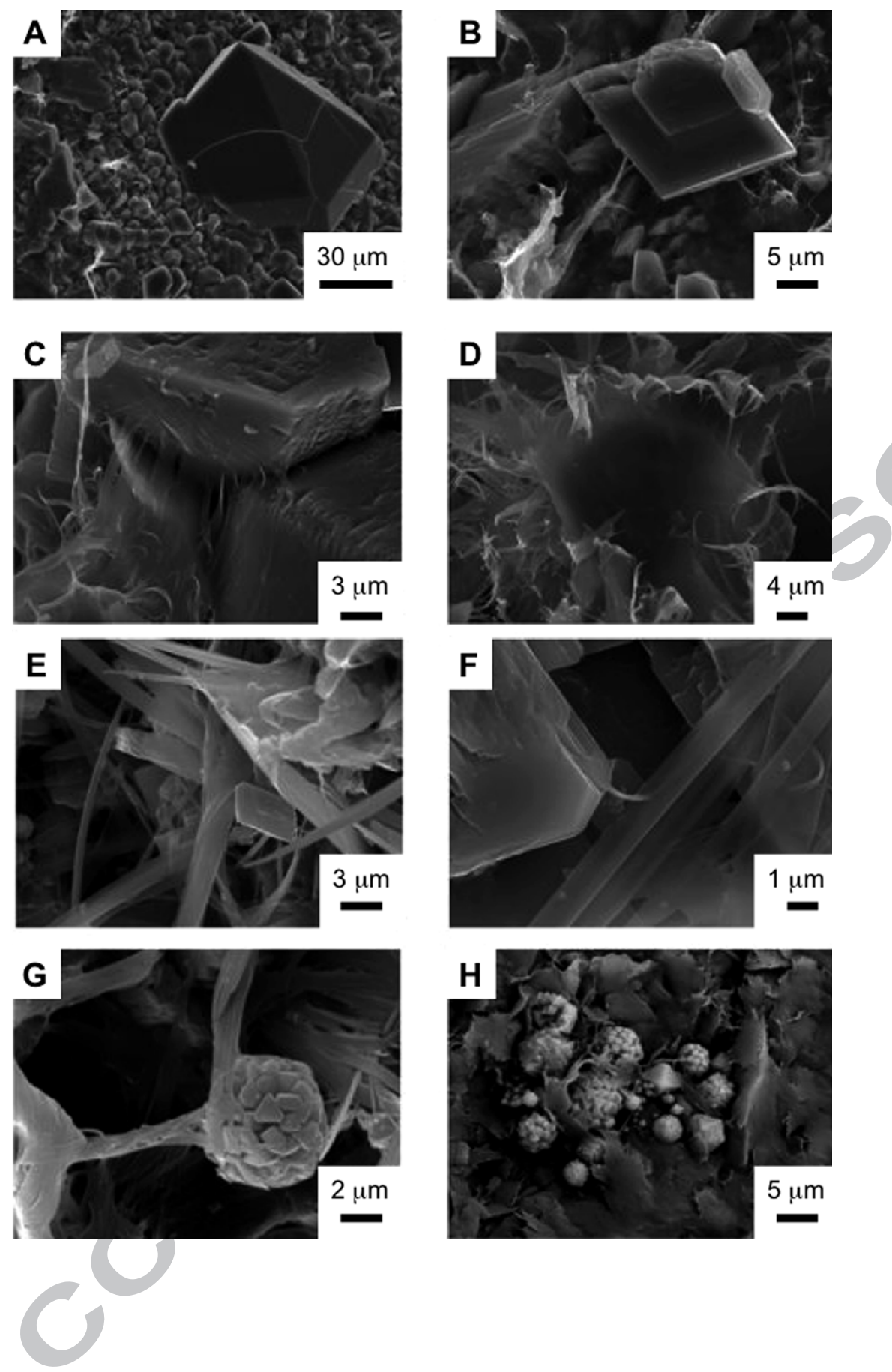


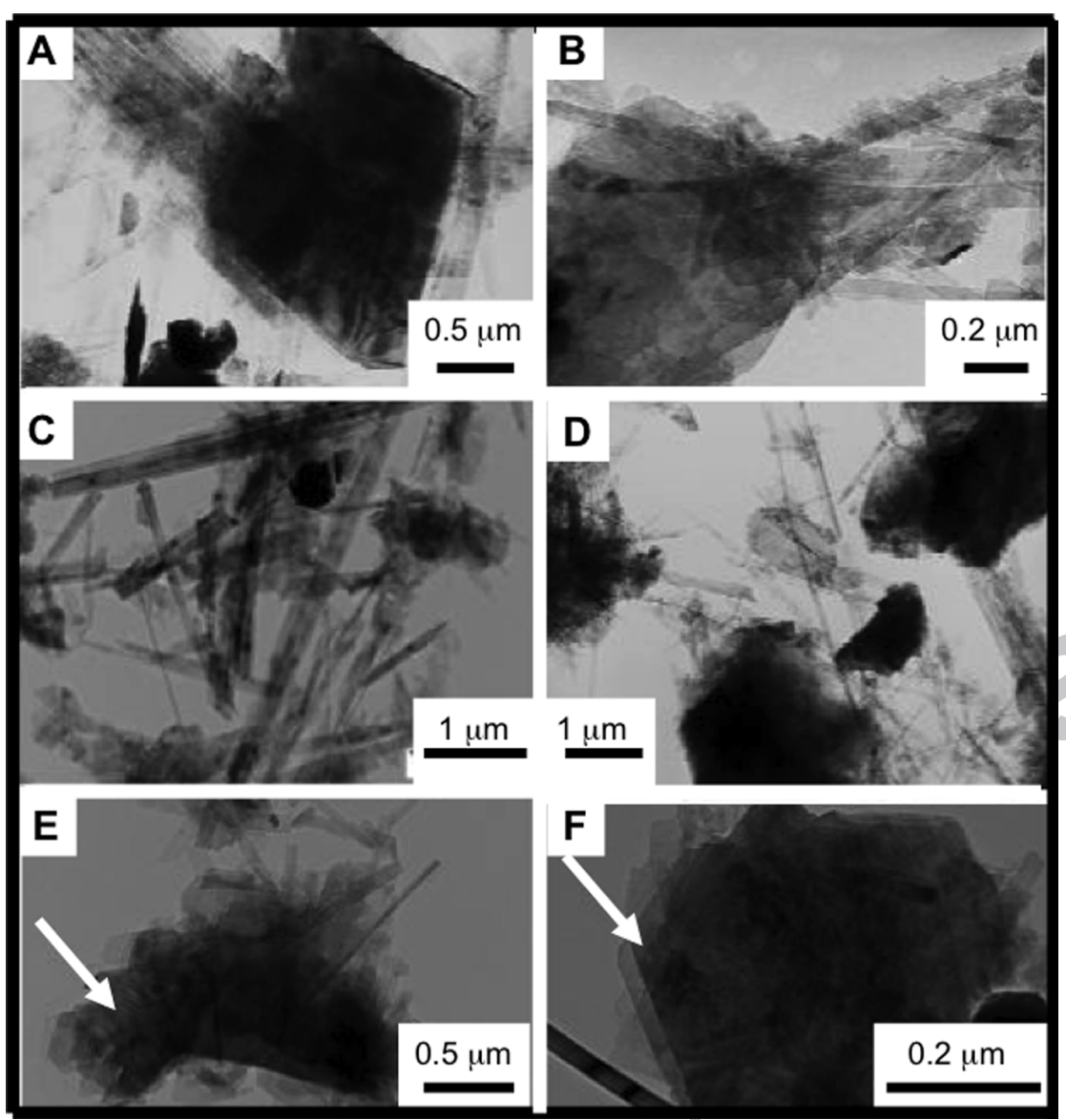




\section{ACCEPTED MANUSCRIPT}

\begin{tabular}{|c|c|c|c|c|c|}
\hline Parameters & $\begin{array}{c}\text { STAGE } 0 \\
\text { (deposition) }\end{array}$ & STAGE 1 & STAGE 2 & STAGE 3 & STAGE 4 \\
\hline & $\begin{array}{l}\text { detrital sequence of } \\
\text { Qz + K-spar + clays + } \\
\text { (apatite + zircon) }\end{array}$ & $\begin{array}{l}\text { authigenesis of } \\
\text { kaolinite }+ \text { dickite } \\
\text { weathering of Qz + } \\
\text { K-spar }\end{array}$ & $\begin{array}{l}\text { authigenesis of Qz+ } \\
\text { K-spar }\end{array}$ & $\begin{array}{l}\text { authigenesis of } \\
\text { platyillite }\end{array}$ & $\begin{array}{l}\text { authigenesis of } \\
\text { filamentousillite + } \\
\text { pyrite }\end{array}$ \\
\hline timing & $250-240 \mathrm{Ma}$ & & & $180 \mathrm{Ma}(?)$ & $150 \mathrm{Ma}(?)$ \\
\hline temperature & $10-20^{\circ} \mathrm{C}$ & & $50-95^{\circ} \mathrm{C}$ & $>110^{\circ} \mathrm{C}(?)$ & $110^{\circ} \mathrm{C}<>95^{\circ} \mathrm{C}(?)$ \\
\hline fluid chemistry & & & & & reduced $\mathrm{pH}$ \\
\hline photos (Figure \#) & & $2 \mathrm{C}$ & $2 \mathrm{~A} ; 2 \mathrm{~B}$ & $\begin{array}{l}\text { 2D; 2F; 3A; 3D; } \\
\text { 3E; 3F; }\end{array}$ & $\begin{array}{l}2 \mathrm{C} ; 2 \mathrm{D} ; 2 \mathrm{E} ; 2 \mathrm{~F} ; 2 \mathrm{G} ; \\
2 \mathrm{H} ; 3 \mathrm{~A} ; 3 \mathrm{C} ; 3 \mathrm{D} ;\end{array}$ \\
\hline
\end{tabular}



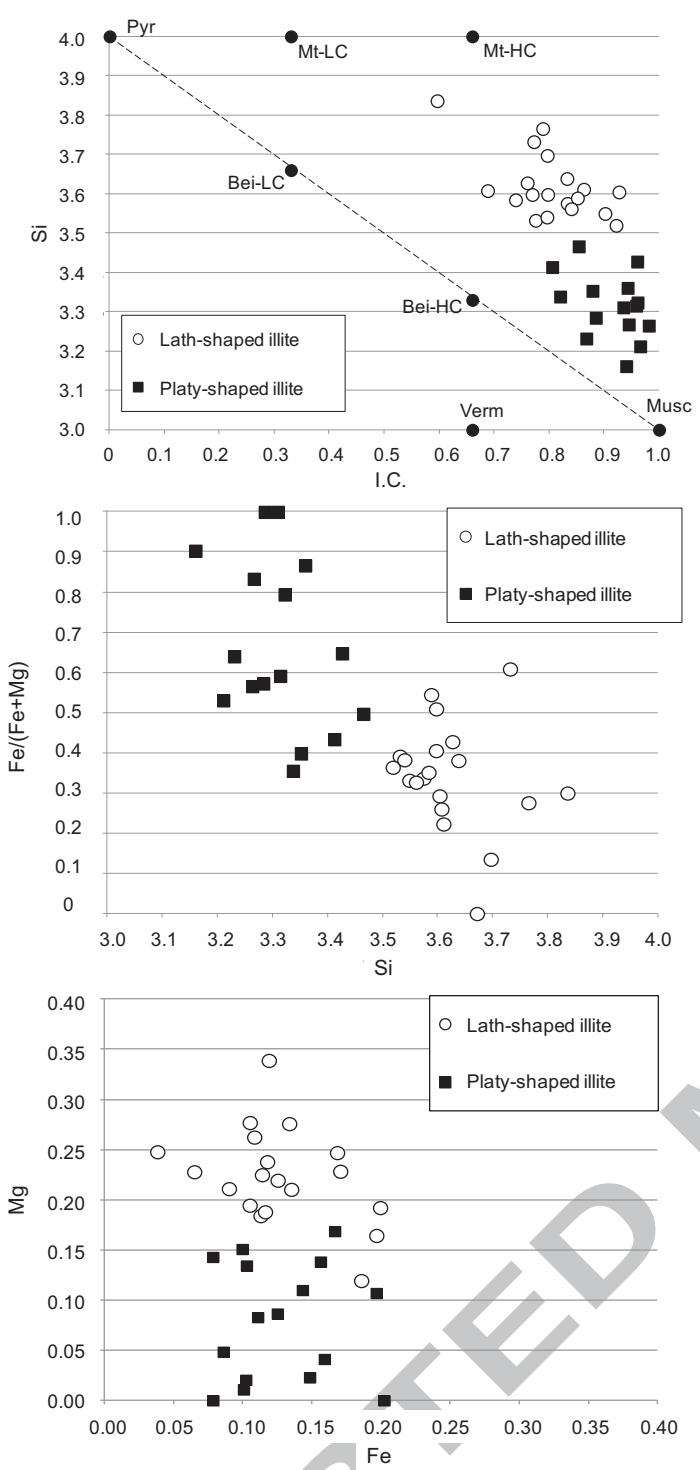


\section{ACCEPTED MANUSCRIPT}
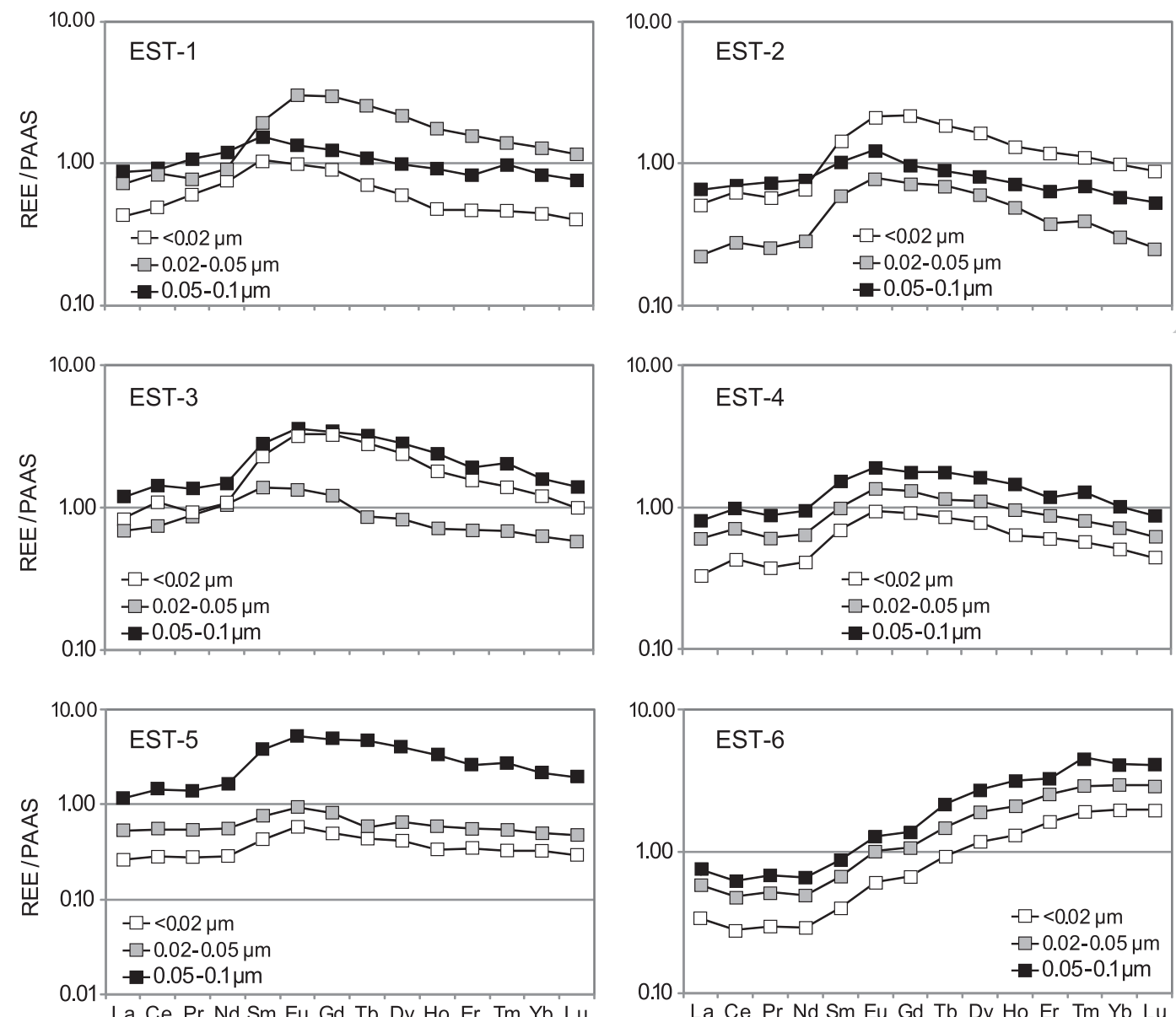
EST-1
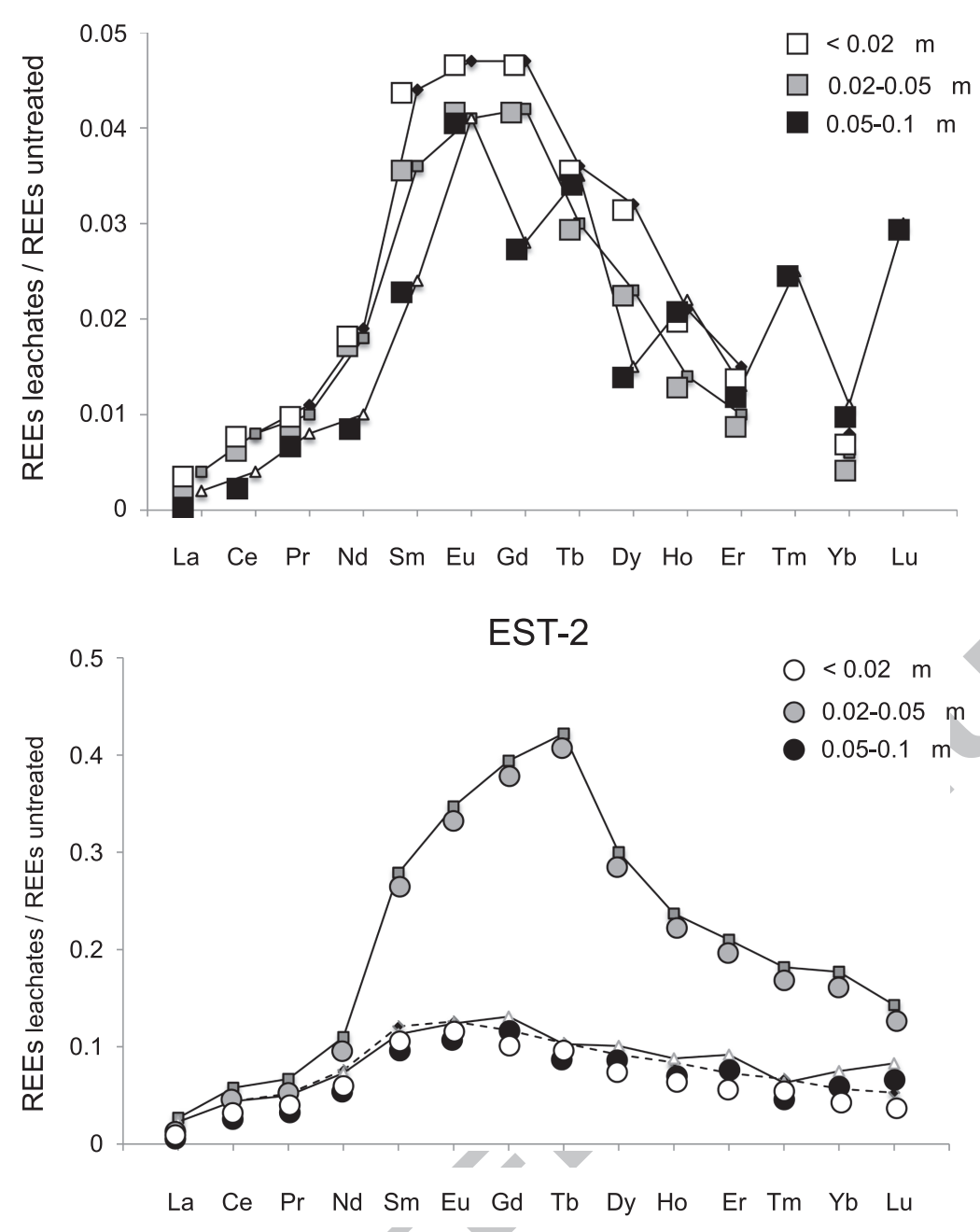

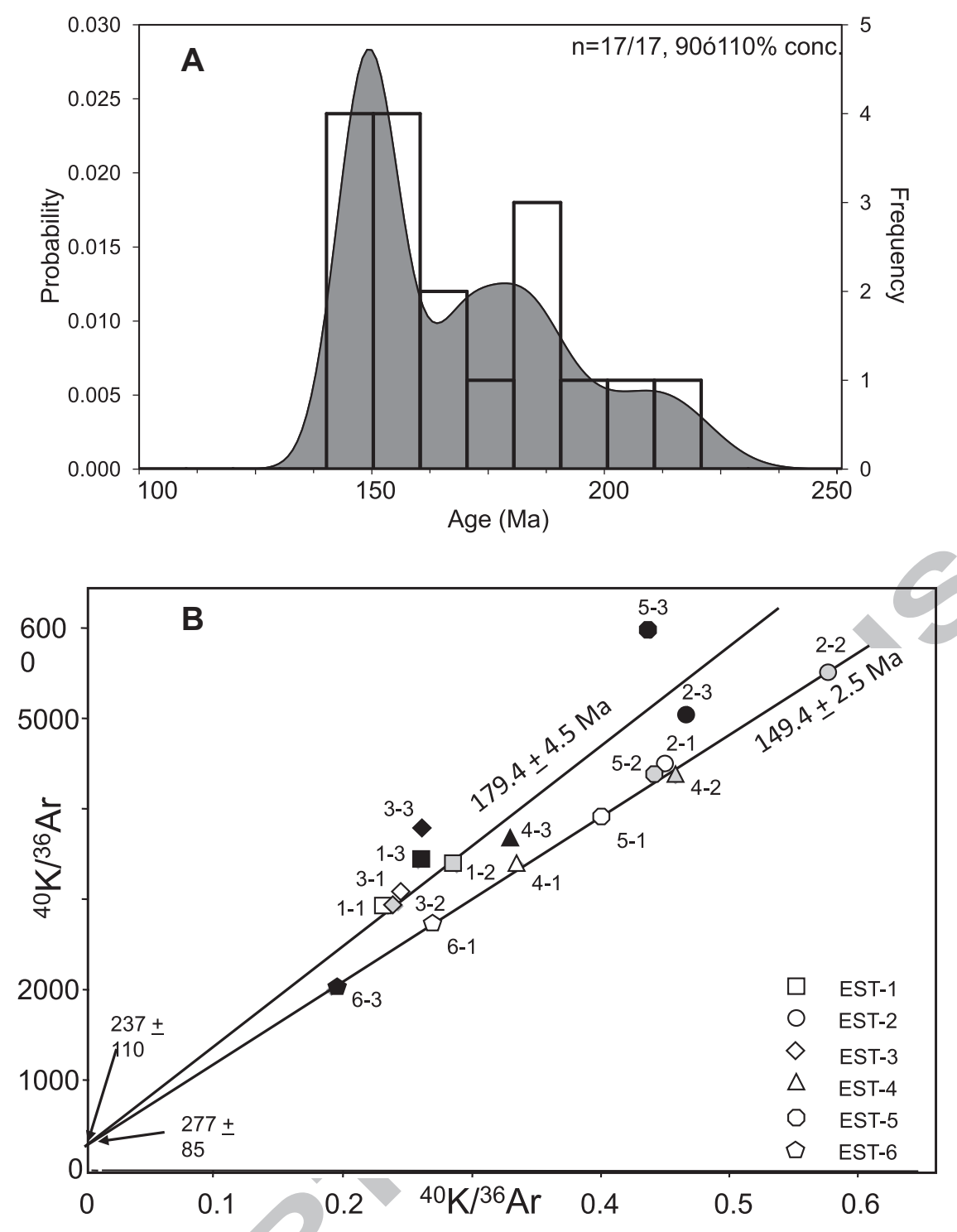


\section{ACCEPTED MANUSCRIPT}
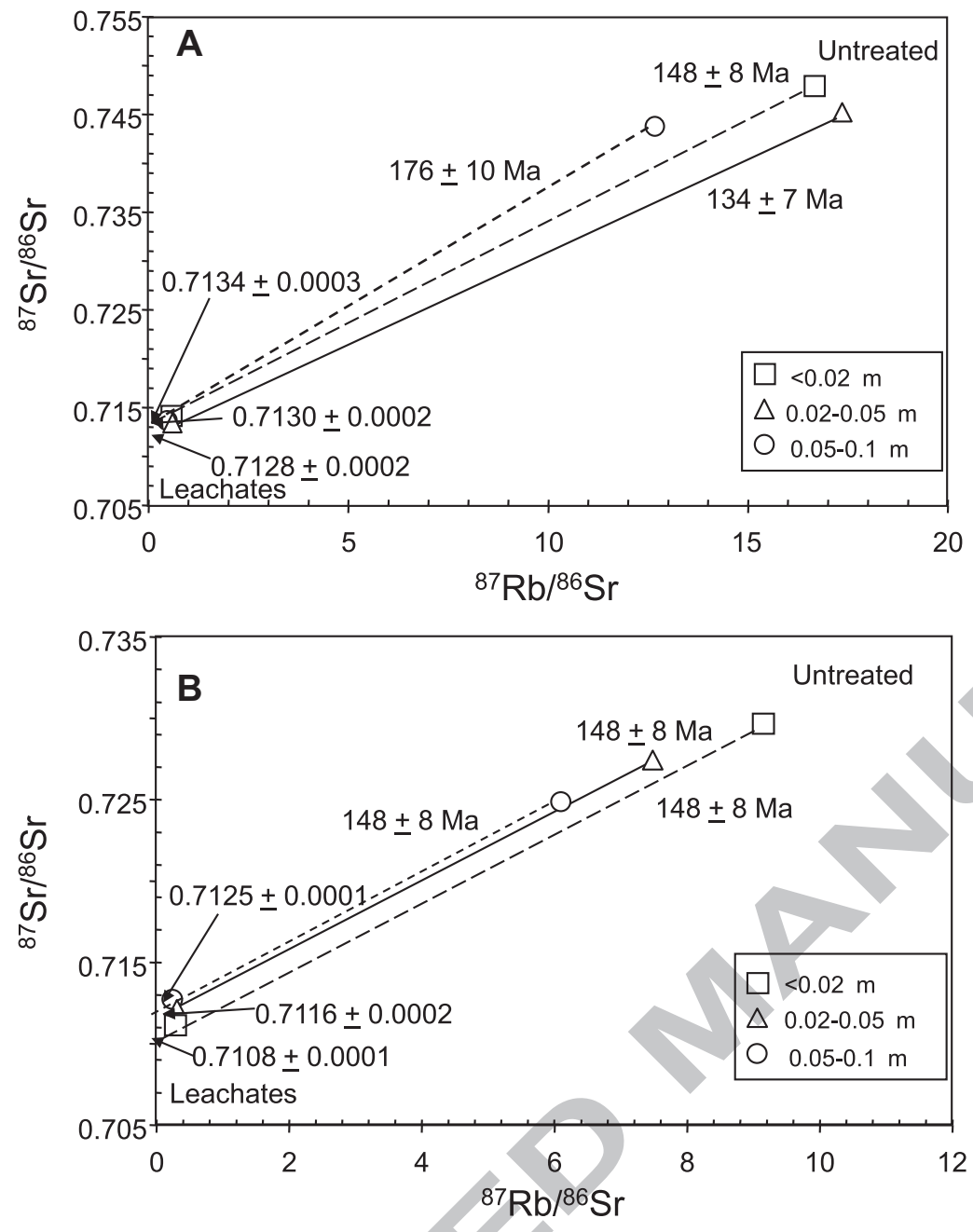


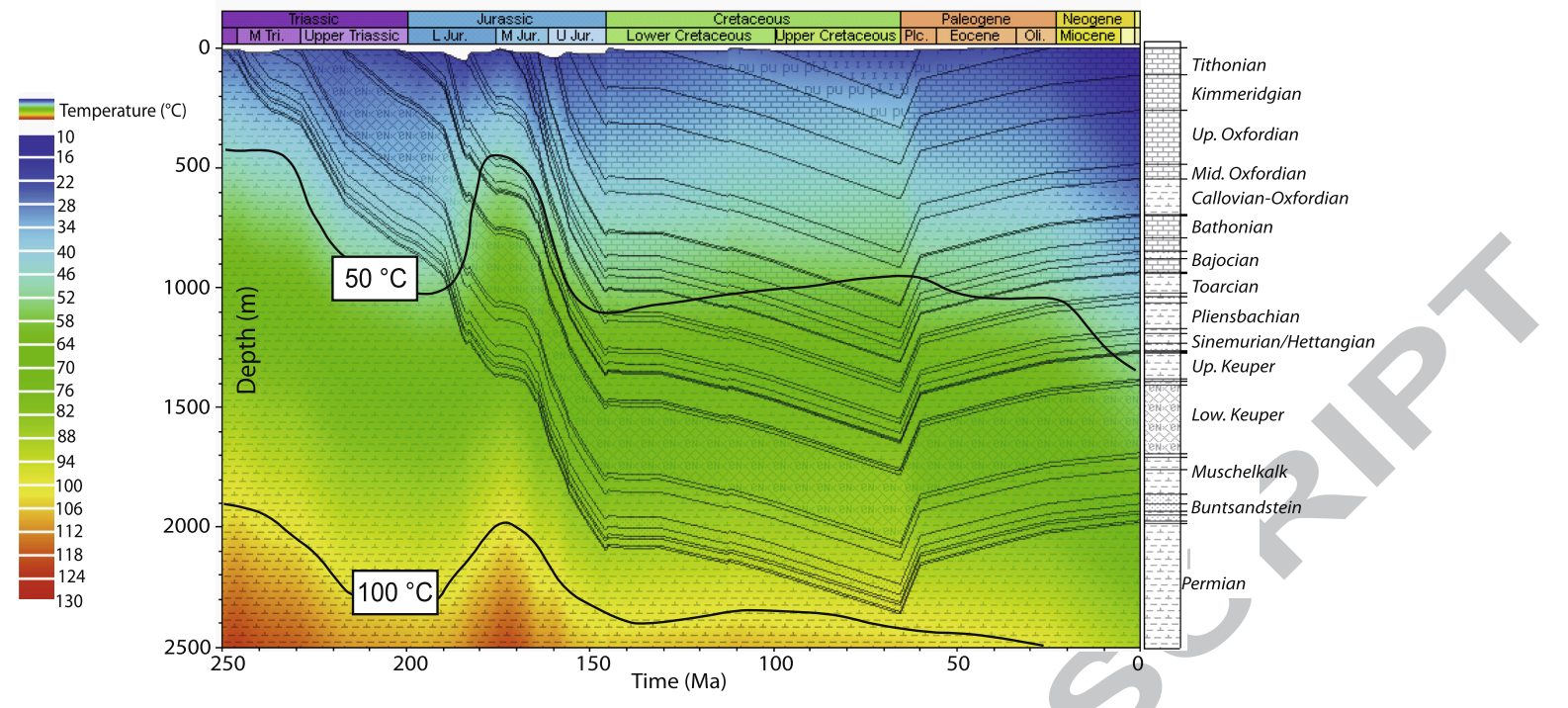




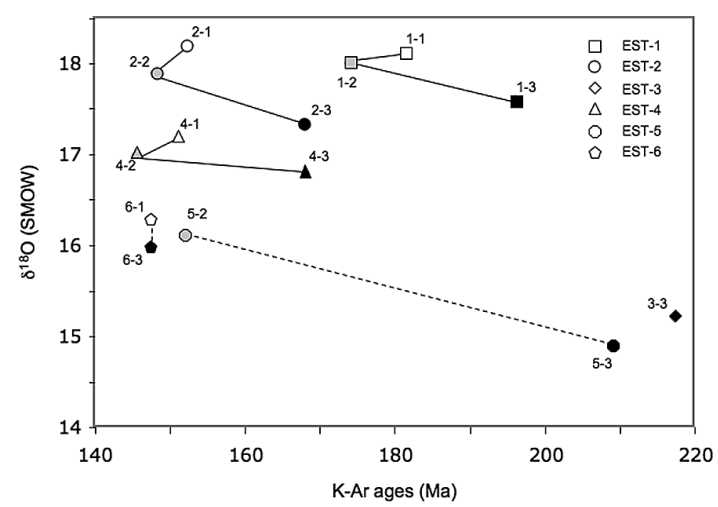




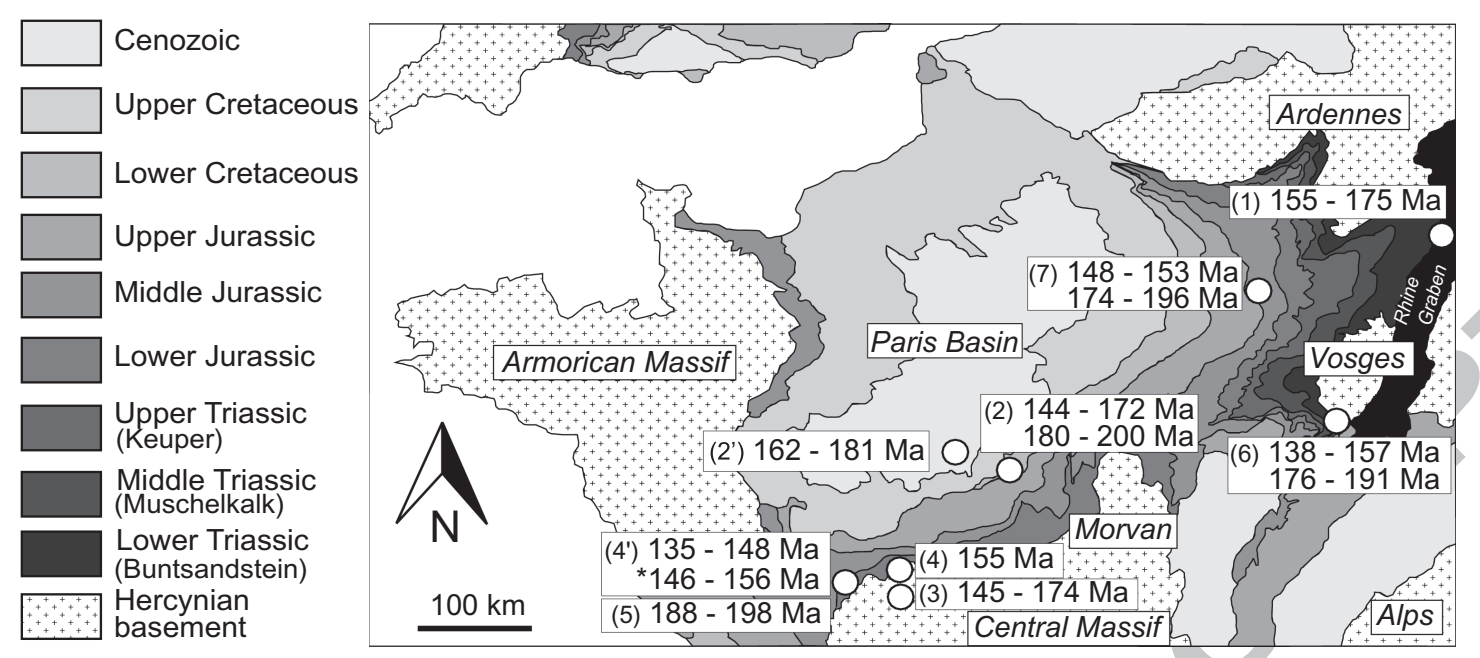

